\title{
Archeological Impact Evaluations and Surveys in the Texas Department of Transportation's Corpus Christi, Laredo, Pharr, and San Antonio Districts 2003-2005
}

Timothy B. Griffith

Prewitt and Associates, Inc.

Ross C. Fields

Prewitt and Associates, Inc.

E. Frances Gadus

Prewitt and Associates, Inc.

Karl W. Kibler

Cross Timbers Geoarcheological Services

Follow this and additional works at: https://scholarworks.sfasu.edu/ita

Part of the American Material Culture Commons, Archaeological Anthropology Commons, Environmental Studies Commons, Other American Studies Commons, Other Arts and Humanities Commons, Other History of Art, Architecture, and Archaeology Commons, and the United States History Commons

Tell us how this article helped you.

This Article is brought to you for free and open access by the Center for Regional Heritage Research at SFA ScholarWorks. It has been accepted for inclusion in Index of Texas Archaeology: Open Access Gray Literature from the Lone Star State by an authorized editor of SFA ScholarWorks. For more information, please contact cdsscholarworks@sfasu.edu. 


\section{Archeological Impact Evaluations and Surveys in the Texas Department of Transportation's Corpus Christi, Laredo, Pharr, and San Antonio Districts}

2003-2005

Creative Commons License

(c) (i) (अ)

This work is licensed under a Creative Commons Attribution-NonCommercial-No Derivative Works 4.0 International License. 


\title{
ARCHEOLOGICAL IMPACT EVALUATIONS AND SURVEYS IN THE TEXAS DEPARTMENT OF TRANSPORTATION'S \\ CORPUS CHRISTI, LAREDO, PHARR, AND \\ SAN ANTONIO DISTRICTS, 2003-2005
}

\author{
by \\ Timothy B. Griffith \\ Ross C. Fields \\ E. Frances Gadus \\ and \\ Karl W. Kibler \\ with contributions by \\ Jennifer K. McWilliams \\ Stephen M. Thompson \\ Tim Gibbs \\ and \\ Cory J. Broehm \\ Principal Investigator: Ross C. Fields \\ REPORTS OF INVESTIGATIONS, NUMBER 144 \\ Prewitt and Associates, Inc. \\ Cultural Resources Services \\ Austin, Texas \\ ARCHEOLOGICAL STUDIES PROGRAM, REPORT NO. 85 \\ Texas Department of Transportation \\ Environmental Affairs Division
}

December 2005

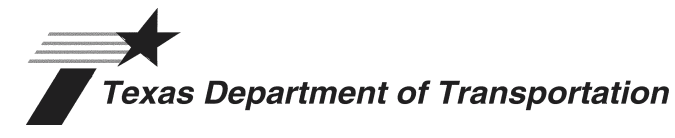

TEXAS ANTIQUITIES PERMIT NO. 3096 


\title{
ARCHEOLOGICAL IMPACT EVALUATIONS AND SURVEYS IN THE TEXAS DEPARTMENT OF TRANSPORTATION'S \\ CORPUS CHRISTI, LAREDO, PHARR, AND SAN ANTONIO DISTRICTS, 2003-2005
}

\author{
by \\ Timothy B. Griffith \\ Ross C. Fields \\ E. Frances Gadus \\ and \\ Karl W. Kibler \\ with contributions by \\ Jennifer K. McWilliams \\ Stephen M. Thompson \\ Tim Gibbs \\ and \\ Cory J. Broehm \\ Principal Investigator: Karl W. Kibler \\ REPORTS OF INVESTIGATIONS, NUMBER 144 \\ Prewitt and Associates, Inc. \\ Cultural Resources Services \\ Austin, Texas \\ ARCHEOLOGICAL STUDIES PROGRAM, REPORT NO. 85 \\ Texas Department of Transportation \\ Environmental Affairs Division
}

December 2005

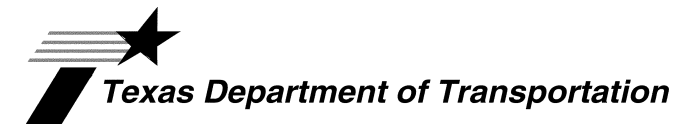

TEXAS ANTIQUITIES PERMIT NO. 3096 


\section{TABLE OF CONTENTS}

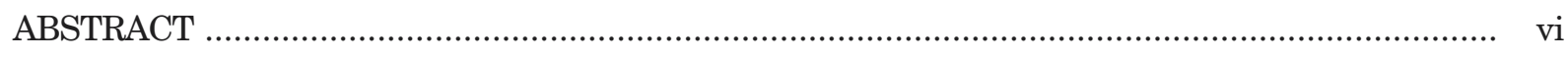

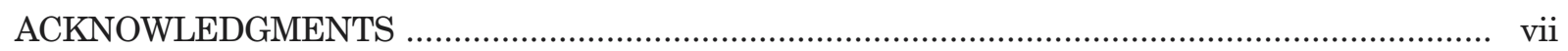

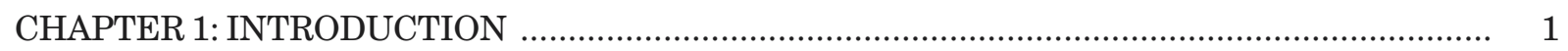

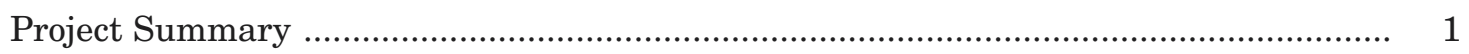

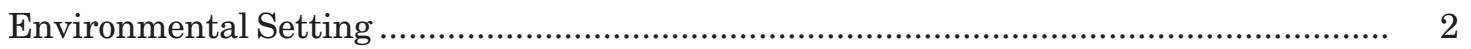

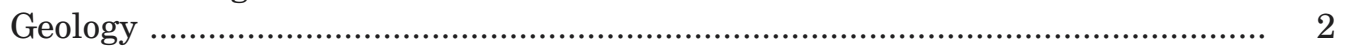

Natural Regions and Vegetation ................................................................ 2

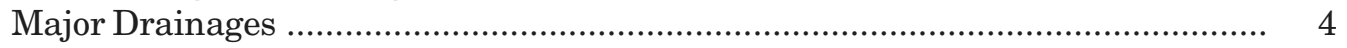

CHAPTER 2: SYNOPSIS OF NATIVE AMERICAN CULTURE HISTORY ............................... 9

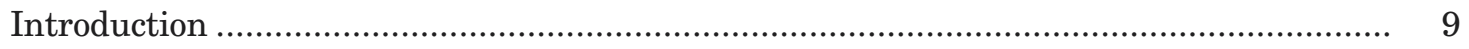

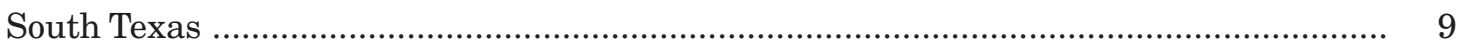

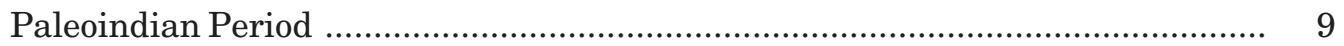

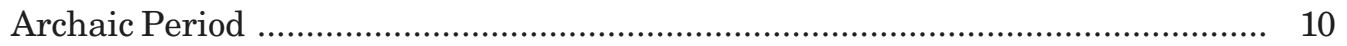

Late Prehistoric Period ............................................................................... 11

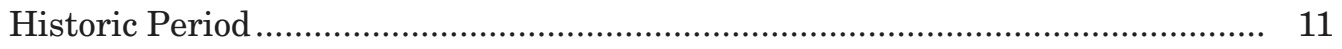

Coastal Bend and Central Coastal Plain ..................................................................... 12

Paleoindian Period .................................................................................... 13

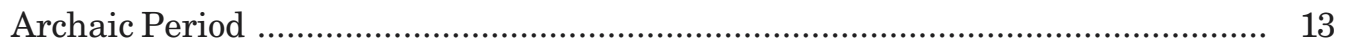

Late Prehistoric Period .................................................................................. 15

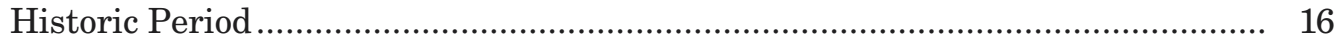

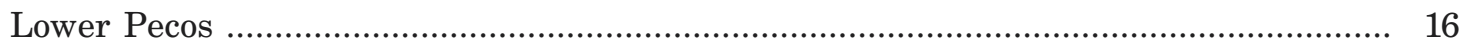

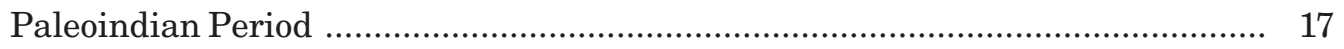

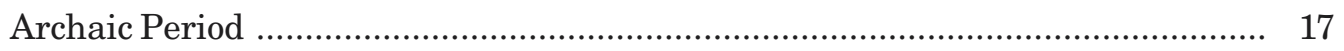

Late Prehistoric Period ......................................................................... 18

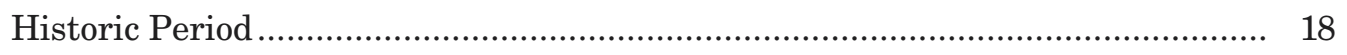

Southeast Margin of Central Texas ..................................................................... 18

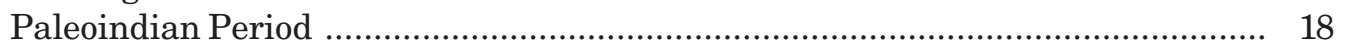

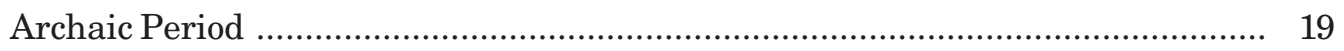

Late Prehistoric Period ........................................................................ 21

Historic Period ........................................................................................... 22

CHAPTER 3: SUMMARY OF IMPACT EVALUATIONS AND SURVEYS ................................ 23

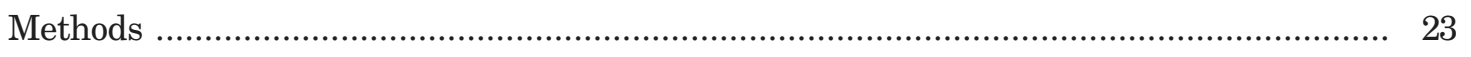

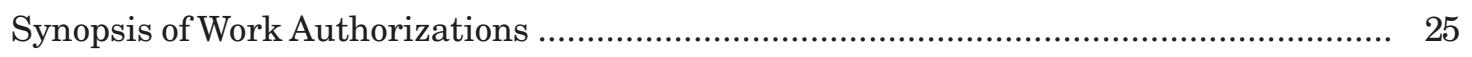

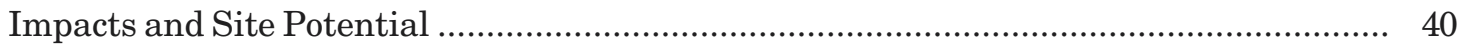

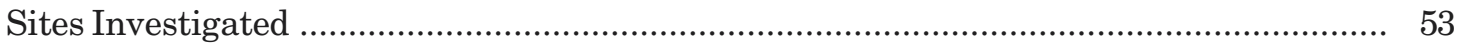

Work Authorization 4: 41DM150 ............................................................ 53

Work Authorization 4: 41ZV344 …........................................................... 53 


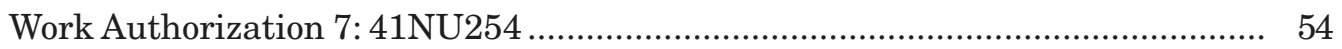

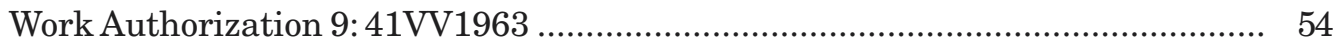

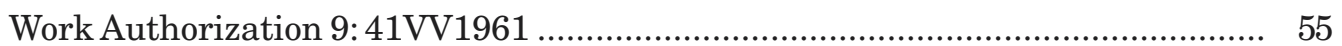

Work Authorization 14: 41WB17 and 41WB18 ............................................... 56

Work Authorization 14: 41WB214, 41WB456, and 41WB457 .......................... 57

Work Authorizations 14 and 30:41WB619 and 41WB620 ............................... 57

Work Authorizations 15 and 27: 41LS98 ................................................... 58

Work Authorization 16: 41KY13, 41KY28, 41KY51 ........................................ 58

Work Authorization 16: 41MV57 and 41 MV58 …....................................... 59

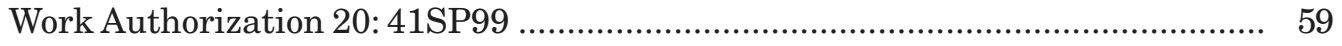

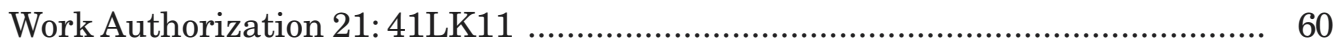

Work Authorizations 23 and 26: 41DM3 and 41DM49 ................................. 61

Work Authorization 23: 41DM4 …....................................................... 62

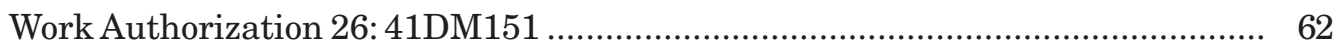

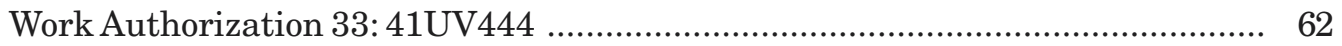

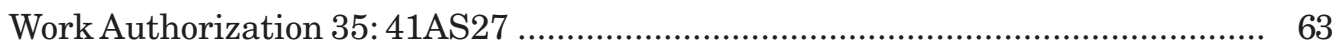

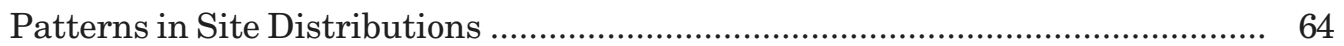

Utility of Existing Methods ........................................................................... 65

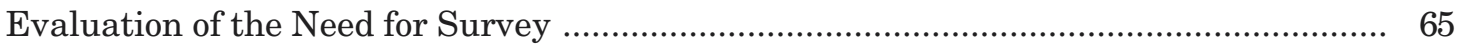

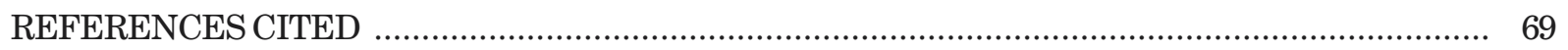

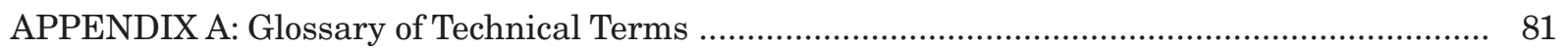

APPENDIX B: Letters and Letter Reports for Impact Evaluations and Surveys ........................ 85 


\section{FIGURES}

1. Locations of the Corpus Christi, Laredo, Pharr, and San Antonio Districts

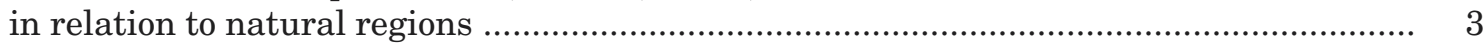

2. Major drainages in the Corpus Christi, Laredo, Pharr, and San Antonio Districts ............ 5

3. Map of the study area showing the locations of all Impact Evaluations and Surveys ......... 24

4. Schematic cross section of a bridge approach showing common disturbances .................. 41

\section{TABLES}

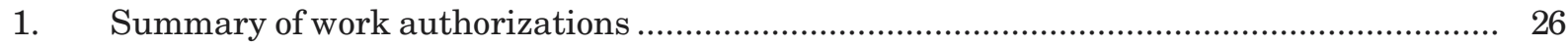

2. Summary of existing impacts by work authorization .................................................. 42

3. Summary of archeological sites investigated ........................................................... 54 


\begin{abstract}
This document constitutes the final report of work done by Prewitt and Associates, Inc. (PAI), under a contract from the Texas Department of Transportation (TxDOT) to provide archeological services in four TxDOT districts-Corpus Christi, Laredo, Pharr, and San Antonio. Under this contract, PAI completed Impact Evaluations and Surveys to assist TxDOT in meeting the requirements of their Memorandum of Understanding with the Texas Historical Commission and a Programmatic Agreement between the Advisory Council on Historic Preservation, the Federal Highway Administration, the Texas Historical Commission, and TxDOT. The contract began on March 17, 2003, and the last work authorization was issued on February 17, 2005. During those two years, fieldwork was done under 33 work authorizations.

The 33 work authorizations consisted of 53 Impact Evaluations, 33 Surveys, and 2 Surveys with Geoarcheological Evaluation. Combined, these work authorizations entailed efforts at 47 bridge replacements, 4 bridge rehabilitation projects, 2 locations where new bridges will be built, 20 road rehabilitation or widening projects (many also involving bridge replacements or upgrades), 1 interstate highway rest area replacement, 3 drainage improvement projects, 2 curve realignment projects, 3 projects involving construction of new roads, 1 project involving construction of a railroad grade separation, 1 pedestrian bridge construction project, 1 project involving construction of a water taxi landing, 1 project involving construction of a hike-and-bike trail, 1 project involving modification of a highway interchange, and 1 project involving documentation of an archeological site disturbed by placement of a buried utility line. During completion of these work authorizations, 26 newly discovered or previously recorded archeological sites were investigated, although in the case of 9 previously recorded sites, no archeological remains were observed in the areas that will be impacted by the proposed Transportation Activities.

Three of the Impact Evaluations led to recommendations that survey could be needed before construction, in some cases depending on whether new right of way would be required. The other 50 Impact Evaluations resulted in recommendations that no survey be required before construction based on the limited potential for sites with good integrity. Thirteen of the Surveys investigated a total of 3 newly recorded and 12 previously recorded sites. Of these 15 sites, 1 was considered eligible for listing in the National Register of Historic Places and designation as a State Archeological Landmark, and 1 was recommended as needing testing to assess eligibility. The other 33 Surveys either did not find any archeological sites, or they investigated sites that could be assessed as ineligible for National Register listing and State Archeological Landmark designation using the survey data. The records and artifacts generated by the project are curated at the Texas Archeological Research Laboratory.
\end{abstract}




\section{ACKNOWLEDGMENTS}

A number of people contributed to the successful completion of this project. Tim Meade, Maureen Brown, Scott Pletka, and A. Joachim McGraw managed the contract for the Archeological Studies Program, Environmental Affairs Division, Texas Department of Transportation. At Prewitt and Associates, Karl W. Kibler served as principal investigator, and Ross C. Fields was the quality control officer. Timothy B. Griffith, E. Frances Gadus, Jennifer K. McWilliams, Stephen M. Thompson, Tim Gibbs, and Cory J. Broehm served as project archeologists. Mr. Kibler filled the position of project geoarcheologist. These people performed most of the fieldwork and were responsible for writing most of the reports on individual work authorizations included as Appendix B; the site descriptions included in the body of the report are extracted from the work authorization reports. Mr. Kibler and Mr. Griffith prepared the Environmental Setting section of the report, and Mr. Kibler wrote one of the culture history summaries (Southeast Margin of Central Texas). Ms. Gadus wrote the culture history summary for the Coastal Bend and Central Coastal Plain. The other two culture history summaries (South Texas and Lower Pecos) were written by personnel with SWCA Environmental Consultants, Inc., under a previous TxDOT contract. Mr. Griffith and Mr. Fields wrote the remainder of the report. Support at Prewitt and Associates was provided by Karen M. Gardner (laboratory supervision, photograph cataloging, and curation), Brian J. Wootan and Sandra L. Hannum (production of graphics), and Jane Sevier (report editing and production). 



\section{INTRODUCTION}

\section{PROJECT SUMMARY}

This document constitutes the final report of work done by Prewitt and Associates, Inc. (PAI), under a contract (\#573XXSA003) with the Texas Department of Transportation (TxDOT) to provide archeological impact evaluations, surveys, and other services in four TxDOT Districts-Corpus Christi, Laredo, Pharr, and San Antonio-stretching from central to south Texas. The contract began on March 17, 2003, and the last work authorization was issued on February 17, 2005. During those two years, fieldwork was done under 33 work authorizations.

Under this contract, PAI completed Impact Evaluations and Surveys to assist TxDOT in meeting the requirements of their Memorandum of Understanding with the Texas Historical Commission and a Programmatic Agreement among the Advisory Council on Historic Preservation, the Federal Highway Administration, the Texas Historical Commission, and TxDOT. TxDOT defines Impact Evaluations as "on-site inspection ... documenting existing impacts or other conditions which may preclude the presence of intact archeological deposits within the project area for a proposed Transportation Activity." Impact Evaluations are thus an initial step to determine whether survey of a particular area is warranted, given the anticipated effects of the project, the existing level of disturbance, and the likelihood of archeological deposits in good context.

TxDOT defines Surveys as "archeological field work ... of a proposed Transportation Activity to locate archeological remains, if any, including on-foot examination of the surface, shovel testing, and subsurface trenching by mechanical means where appropriate." As described below, PAI completed 33 work authorizations involving 53 Impact Evaluations and 35 Surveys. Two of the surveys included geoarcheological evaluation, and 33 did not. Most of these projects focused on locations where bridges will be replaced. Other kinds of Transportation Activities included roadwidening projects, road realignments, construction of new roads or bridges, construction of a hike-and-bike trail, construction of new rest areas, upgrading of existing bridges and culverts, construction of a railroad grade separation, and cleaning and grading of drainage ditches.

The body of this report consists of three major sections. A brief characterization of the environmental setting of the four TxDOT districts follows this introduction. Four synopses of Native American culture histories are presented next. One covers the south Texas region and encompasses all of the Pharr District and the southern portions of the Laredo and San Antonio Districts. The second discusses the coastal bend area and central coastal plain, which includes all of the Corpus Christi District and part of the southern San Antonio District. The third discusses the lower Pecos region and covers the northwestern portion of the Laredo District, namely Val Verde County. The fourth discusses the southeast margin of central Texas, which covers the northern part of the San Antonio District.

Following the culture history synopses is a section summarizing the work done under this contract. It discusses the methods employed in the Impact Evaluations and Surveys and evaluates their effectiveness. It also presents tables listing the Impact Evaluations and Surveys and 
their topographic and geologic settings, soils, land use, and presence or absence of archeological sites. Existing disturbances that affected the potential of project areas to contain sites with sufficient integrity to be eligible for National Register of Historic Places listing or State Archeological Landmark designation are listed and discussed. The sites investigated are described next. This section also provides an evaluation of the need for survey based on the results of this project. A references cited section and two appendixes follow the body of the report. Appendix A is a glossary of technical terms, and Appendix B, which is included on CD-ROM in only selected reports, contains the letters and reports submitted to TxDOT for all Impact Evaluations and Surveys done under the contract.

\section{ENVIRONMENTAL SETTING}

\section{Geology}

The San Antonio, Laredo, Corpus Christi, and Pharr districts cover a 38-county area extending from central Texas south to the Rio Grande and the Gulf coast. Most of this fourdistrict area lies within the Western Gulf Coastal Plain physiographic province, and the northern portion is within the Great Plains province (Fenneman 1931, 1938). Geologically, the San Antonio District straddles a deep-seated fracture zone and site of past orogenic events that separates the stable continental interior to the west from the subsiding Gulf basin to the east and southeast.

During the Cretaceous period as the Gulf of Mexico formed, clastic sediments and carbonates were deposited along the broad marginal shelf of the Gulf Basin. These Lower Cretaceous sandstones and limestones found throughout the dissected margins of the Edwards Plateau represent cycles of marine transgression and regression. By Upper Cretaceous times, infilling of the Gulf basin and shoreline progradation predominated, as Upper Cretaceous sandstones and mudstones throughout the central portion of the San Antonio District show. Marine regression and shoreline progradation continued during the Tertiary and Quaternary and are represented by various sandstone and mudstone units present throughout all four districts.

\section{Natural Regions and Vegetation}

The different rock units have a major influence on the topography, flora, and hydrology across the four-district area. A number of different natural regions lie within the area, due in part to these lithological variations (Figure 1). The Blackland Prairie extends into the east part of the San Antonio District, as does the Oak Woodlands. The Brush Country region covers large portions of the San Antonio, Corpus Christi, and Pharr Districts and most of the Laredo District. The Live Oak-Mesquite Savanna of the Edwards Plateau covers the northern part of the San Antonio District and most of the northwestern corner of the Laredo District. The Stockton Plateau of the Trans Pecos region occupies the far northwestern part of the Laredo District. The Upland Prairies and Woods subregion of the Gulf Coast Prairies and Marshes region covers much of the southeastern Corpus Christi District, extending minimally into adjacent parts of the Laredo and Pharr Districts. The Coastal Sand Plains are limited to a large section of the northeastern Pharr District and a small part of the southern Corpus Christi District. The Dunes/Barrier subregion covers the coastal perimeter of the Corpus Christi and Pharr Districts.

The modern plant communities vary from region to region across the four-district area (see Diamond et al. 1987). Diamond et al. (1987:205) classify these plant communities by their dominant growth form (e.g., trees, shrubs, grasses, or forbs). They recognize forests (tree canopy cover greater than 61 percent), woodlands (tree canopy cover $26-60$ percent), shrublands (communities of 0.5-3.0-m-tall shrubs with canopy cover greater than 26 percent), herbaceous communities (dominated by grasses, grass-like plants, or forbs with less than 25 percent canopy cover of woody plants), and swamps and marshes (arboreal-dominated and herbaceous-dominated wetlands).

The Blackland Prairie consists of tall grasslands (dominants greater than $1 \mathrm{~m}$ tall), primarily little bluestem and Indiangrass, with riparian deciduous forests of sugarberry and elm. The Oak Woodlands consists of overcup oak, post oak, and black hickory deciduous forests and bluejack oak, pine, post oak, and blackjack oak deciduous woodlands. 


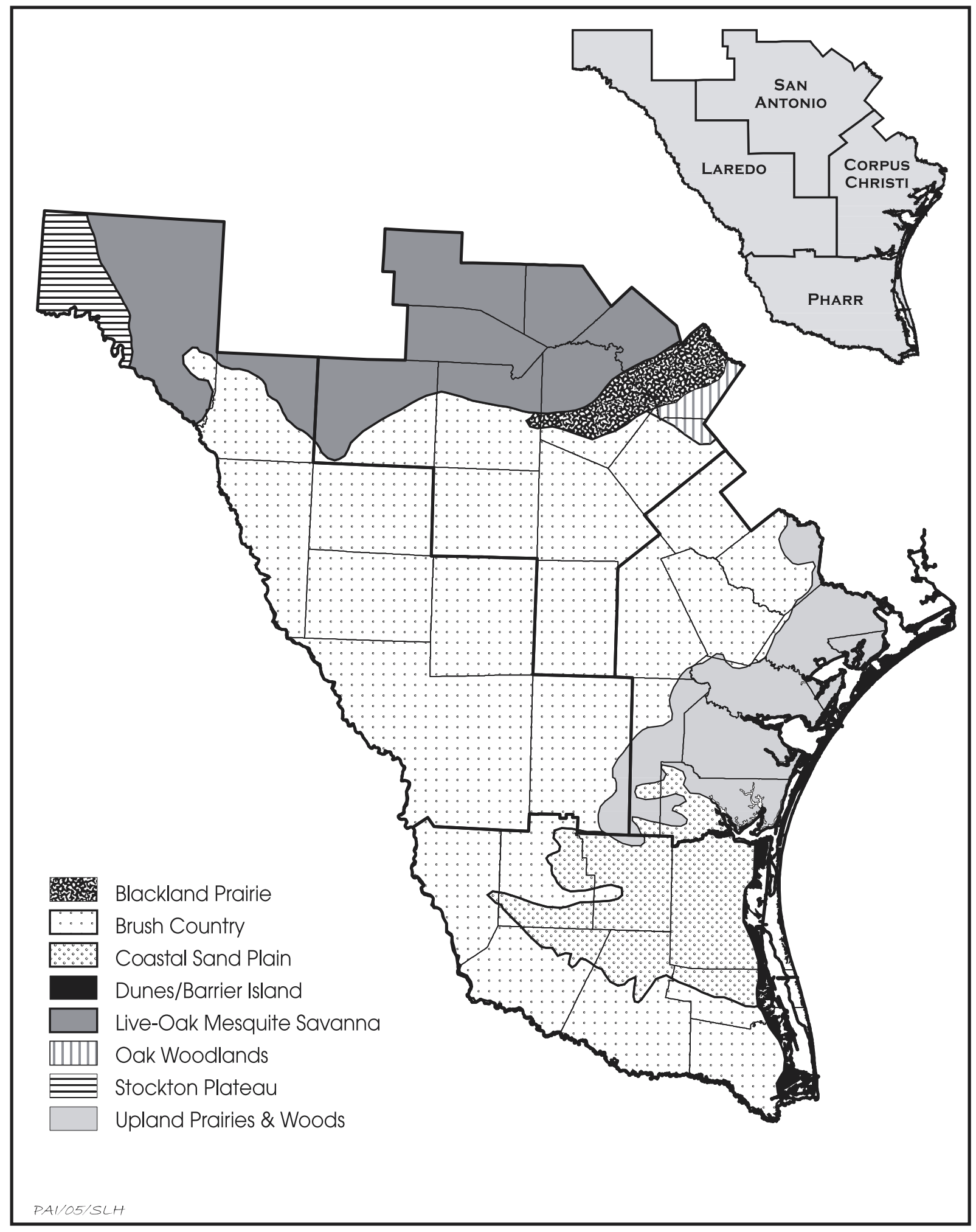

Figure 1. Locations of the Corpus Christi, Laredo, Pharr, and San Antonio Districts in relation to natural regions (from Diamond et al. 1987). 
The Brush Country consists of deciduous forests of hackberry and elm, woodlands of mesquite and huisache, and deciduous shrublands of blackbrush and fern acacia. Evergreen shrublands of ceniza and medium-tall grasslands of cane bluestem are also part of the Brush Country floral community. The Live OakMesquite Savanna consists of deciduous forests of hackberry and elm and deciduous evergreen woodlands of Lacey oak, ashe juniper, and live oak. Medium-tall grasslands are also part of the floral community and consist of curly mesquite and sideoats grama, as are short grasslands (dominants less than $0.5 \mathrm{~m}$ tall) of blue grama, buffalo grass, and tobosa grass. The Stockton Plateau region supports deciduous woodlands of cottonwood, willow, gray oak, mesquite, huisache, netleaf hackberry, and little walnut, as well as evergreen shrublands of redberry juniper and deciduous shrublands of Apache plume, fern acacia, mesquite, sandsage, and Mohr's shin oak. The region also contains medium-tall grasslands dominated by alkali sacaton and fourwing saltbush.

The Upland Prairies and Woods region consists of forests of water oak and live oak; woodlands of pecan, mesquite, huisache, post oak, and live oak; tall grasslands of brownseed paspalum, little bluestem, Indiangrass, gamagrass, marshy cordgrass, rushes, and sedges; and swamps of buttonbush. The Coastal Sand Plains are dominated by evergreen woodlands of live oak and seacoast bluestem, tall grasslands of seacoast bluestem, and marshes of saltgrass, Gulf cordgrass, rushes, and sedges. In the Dunes/ Barrier region, tall grasslands of seacoast bluestem, forb-dominated communities of cenicilla and beach morning glory, and marshes of marshhay cordgrass, smooth cordgrass, Gulf cordgrass, rushes, and sedges are present.

\section{Major Drainages}

The major drainages within the four-district area are the San Antonio, Guadalupe, and Nueces Rivers, along with the Rio Grande (Figure 2). Along the coast, several smaller rivers and large creeks separate the larger drainage basins. They include the Mission and Aransas Rivers and Agua Dulce, Chiltipin, Santa Gertrudis, Los Olmos, and Palo Blanco Creeks.

The San Antonio River is fully contained within the study area. Tributaries of the
San Antonio River head in the northwestern portion of the San Antonio District and merge in and south of the city of San Antonio. Southeast of the city, the San Antonio River turns and flows southeast across the Corpus Christi District before it joins the Guadalupe River just northwest of San Antonio Bay. Headwater tributaries of the San Antonio River with mapped Late Quaternary floodplains and terraces include the Medina River, Medio Creek, Leon Creek, Olmos Creek, Cibolo Creek, and Salado Creek (Bureau of Economic Geology 1974). As these drainages come together, the valley and floodplain widen as the river flows across the Gulf Coastal Plain (Bureau of Economic Geology 1987). Bordered by large Pleistocene terraces, the floodplain of the San Antonio River is up to $4 \mathrm{~km}$ wide. Larger tributaries of the San Antonio River on the Gulf Coastal Plain with mapped alluvium include Manahuilla Creek, Cabeza Creek, Hord Creek, Escondido Creek, and Ecleto Creek.

The Guadalupe River also heads in the northern part of the San Antonio District and flows east and southeast across the full width of the district before exiting it at the GuadalupeGonzales County line. Near its headwaters, the Holocene floodplain of the Guadalupe is very narrow, and floodplain and terrace alluvium are not mapped separately (Bureau of Economic Geology 1974, 1981). As the river enters the canyon lands near the edge of the Edwards Plateau, its valley narrows and the river becomes confined. Floodplain and terraces are not individually mapped, or they are so small that they are not mapped at all. Crossing the Balcones Fault zone, the Guadalupe turns and flows southeast. As it exits the fault zone and enters the Gulf Coastal Plain, its valley and floodplain widen. On the Coastal Plain the upper reaches of the Guadalupe River floodplain are less than $0.5 \mathrm{~km}$ to $4.5 \mathrm{~km}$ wide and flanked sporadically by large Pleistocene terraces. Across the Edwards Plateau, tributaries of the Guadalupe River are small, although tributaries Johnson Creek, Turtle Creek, and Verde Creek all have mapped Holocene and Pleistocene alluvium. On the Gulf Coastal Plain, tributaries are much larger. For example, the San Marcos River, which flows along the northeast edge of the San Antonio District, has a wide Holocene floodplain that is flanked intermittently by Pleistocene terraces.

The Nueces River heads just outside the study area and flows across Uvalde County at 


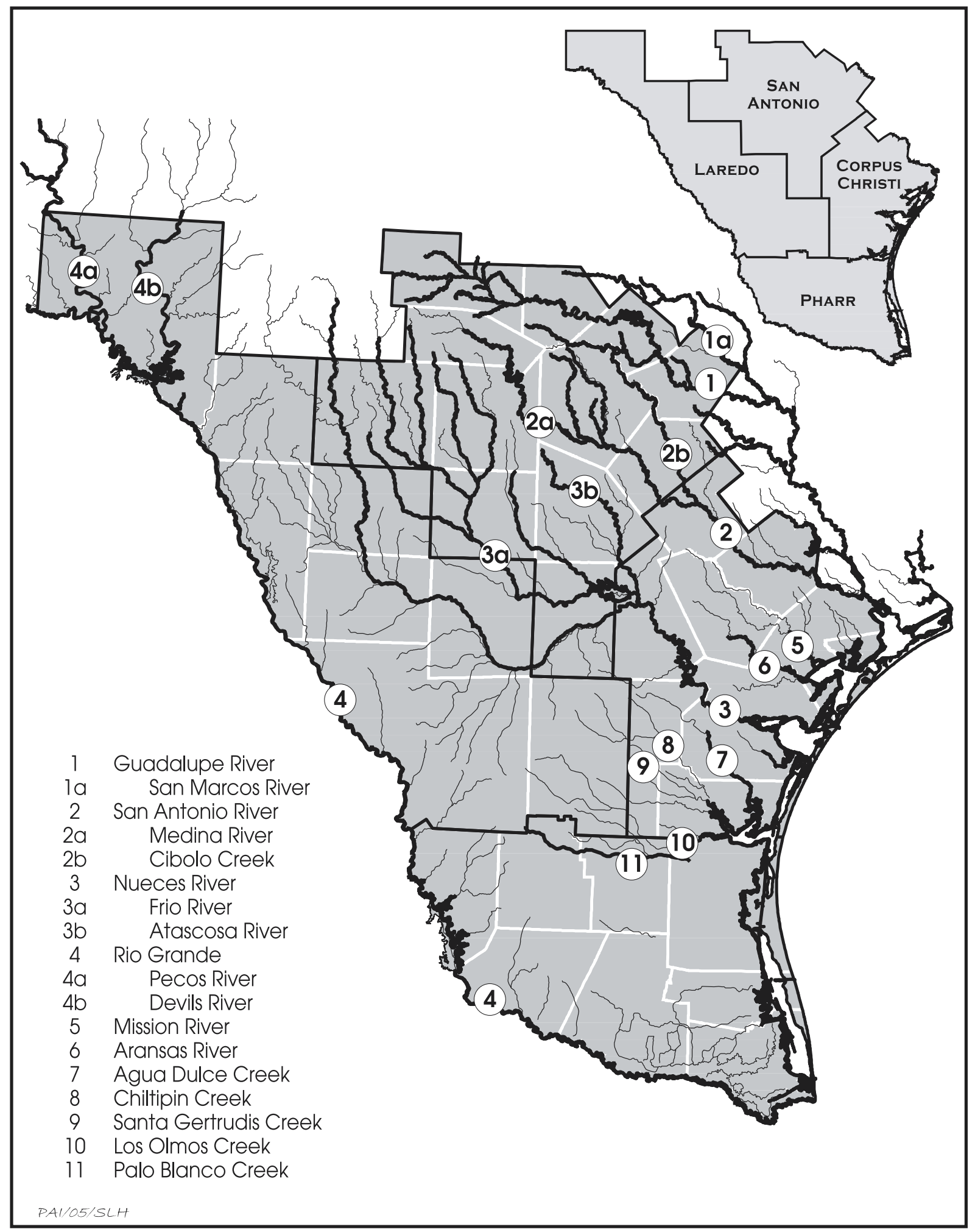

Figure 2. Major drainages in the Corpus Christi, Laredo, Pharr, and San Antonio Districts. 
the western edge of the San Antonio District before entering the Laredo District and flowing south through Zavala County. Along this part of its course, the Nueces River valley is narrow, though the Holocene floodplain and late Quaternary terraces are mapped separately (Bureau of Economic Geology 1974, 1976a, 1977). Tributaries along this portion of the Nueces are small, though a few such as the West Nueces River, Indian Creek, and Sand Creek have mapped Holocene floodplains and Pleistocene terraces. The Nueces then flows east and southeast across Dimmit and La Salle Counties and reenters the San Antonio District in McMullen County. For most of its route across Dimmit County, the river has a wide $(3-5 \mathrm{~km})$ floodplain with mapped Holocene alluvium and occasional Pleistocene terraces (Barnes 1976a). A number of mediumsized and large tributaries with mapped alluvium join the Nueces in this stretch, including Turkey, El Moro, Tortuga, Negro, and Tierra Blanca Creeks. Moving east into La Salle County, the Nueces has a much narrower floodplain $(0.5-1.5 \mathrm{~km})$ with no mapped Pleistocene terraces and only a few small tributaries. By midway through the county, though, the floodplain once again widens to $3-5 \mathrm{~km}$ and is bordered by extensive Pleistocene terrace deposits.

Large tributaries with alluvial floodplains also become more common and include Las Raices, Tecolote, Los Olmos, Black, Quintania, Piedra, Sauz, and Charco Marrano Creeks. Continuing east into the Corpus Christi District, the Nueces River joins with its major tributary, the Frio River, and flows southeast into Nueces and Corpus Christi Bays. Along this portion of its course, the Nueces floodplain is up to $4 \mathrm{~km}$ wide and is up to $6 \mathrm{~km}$ wide at its mouth. Pleistocene terraces flank the Holocene floodplain.

Tributaries along this stretch of the Nueces River include the Frio and another large river, the Atascosa, and many smaller creeks. The Frio and Atascosa Rivers and their network of tributaries display extensive Holocene floodplains up to $2.5 \mathrm{~km}$ wide and large Pleistocene terraces (Bureau of Economic Geology 1976b). The many smaller tributaries with mapped Holocene floodplains include Green Branch Creek, Piscachar Creek, Guadalupe Creek, Elm Creek, Spring Creek, Mule Creek, Cow Creek, Dragon Creek, Salt Branch, and Sulphur Creek.

The Rio Grande is the largest river within the four-district area. It flows along the southern boundaries of the Laredo and Pharr Districts. The Rio Grande and two major tributaries, the Pecos and Devils Rivers, enter the Laredo District in Val Verde County. The Rio Grande then flows southeast along the southern borders of Kinney, Maverick, and Webb Counties, where it leaves the district. The Rio Grande valley in this region is narrow with Holocene floodplains often not mapped at all (Bureau of Economic Geology 1976a, 1976b). Pleistocene terraces are mapped more often and more extensively. Tributaries containing Holocene floodplains or Pleistocene terraces include Sycamore, Pinto, Cow, Chacon, and Santa Isabel. The Rio Grande enters the Pharr District in Zapata County.

There are only a few areas of narrow Holocene floodplains in this portion of the district. But in Starr County below Falcon Reservoir, Holocene floodplains are up to $1 \mathrm{~km}$ wide, and Pleistocene terraces are up to $3 \mathrm{~km}$ wide (Bureau of Economic Geology 1976c). Mediumsized and large tributaries with Holocene alluvium include Arroyo Boleno, San Juan Creek, Arroyo Grande, and Los Olmos Creek. Southeastward to the Gulf of Mexico, the Rio Grande is associated with huge expanses of Holocene alluvium up to $25 \mathrm{~km}$ wide containing many old channels of the river (Bureau of Economic Geology 1976c).

The Mission and Aransas Rivers lie between the San Antonio and Nueces River basins. The Mission River heads in Bee and Goliad Counties in the Corpus Christi District and flows southeast to empty into Mission Bay. The Mission River and its network of tributaries (Blanco, Mucorrera, Indian, and Meio Creeks) have narrow Holocene floodplains along sections of their courses, as well as Pleistocene terraces (Bureau of Economic Geology 1987). The Aransas River and its tributaries head in Bee County and flow southeast, emptying into the southern end of Copano Bay. Like the Mission River and its tributaries, the Aransas River and its tributaries (Aransas, Poesta, and Chiltipin Creeks) have narrow Holocene floodplains along sections of their courses, as well as Pleistocene terraces.

Another complex of large creeks drains the southern part of the Corpus Christi District, the southeastern part of the Laredo District, and the northern edge of the Pharr District, draining into the Gulf at Baffin Bay. These are Agua 
Dulce, Chiltipin, Santa Gertrudis, Los Olmos, and Palo Blanco Creeks. These have narrow to moderately wide (up to $1.5 \mathrm{~km}$ ) floodplains in their western reaches, but Holocene floodplains are rarely mapped to the east near the coast (Bureau of Economic Geology 1975, 1976b). Pleistocene terraces are not mapped along these creeks. Among the many tributaries with narrow floodplains containing Holocene alluvium are Palo Hueco, El Caro, Turo, Muerto, San Diego, Rosita, Narciseno, Piedras Pinto, Las Animas, Parrilla, Concepcion, Agua Poquita, Macho, Cibolo, Laborcitas, and Mesquite Creeks. 



\section{SYNOPSIS OF NATIVE AMERICAN CULTURE HISTORY}

\section{INTRODUCTION}

The current four-district study area lies predominantly within the South Texas archeological region, which is an arbitrary subdivision of the larger South Texas-Northeastern Mexico archeological area. The area also merges with several other archeological regions, including Central Texas, Central Coastal Bend, and the Lower Pecos. The following regional synopses provide basic culture histories for these regions. Those for South Texas and the Lower Pecos were prepared by personnel with SWCA Environmental Consultants, Inc., for a report on an earlier TxDOT contract in the region (Houk and Carpenter 2004). Those for the Coastal Bend and Central Texas were prepared by personnel with Prewitt and Associates, also for an earlier report (Fields et al. 2002).

\section{SOUTH TEXAS}

This synopsis deals with the Pharr District and the southern parts of the Laredo and San Antonio Districts. Although the South Texas region has often been defined as including the Corpus Christi District, recent developments suggest this district is more appropriately defined as part of the Coastal Bend archeological region based on significant distinctions in the archeological record (see Hester 1995; Ricklis 1995). Accordingly, the coastal region is addressed separately below.

It has often been stated that most of the region's sites lack integrity, a result of erosion and repetitive occupation on stable surfaces. The resultant contextual problems have posed difficulties in establishing precise chronologies and defining assemblages or complexes. To redress these problems, there has been a growing emphasis on examining sites with stratified deposits and isolable components with dateable materials. Based on data derived from these efforts, the region's prehistory has undergone several substantial refinements and revisions in recent years. The following chronology incorporates many of these changes.

The archeological remains of South Texas provide evidence of at least 11,000 years of occupation. This long chronology is divided into four basic cultural periods: Paleoindian, Archaic, Late Prehistoric, and Historic. The Archaic is further subdivided into early, middle, and late subperiods. Additionally, within these divisions are a host of phases, foci, complexes, traditions, and horizons, some of which are fairly clearly defined while others remain ambiguous or have become obsolete.

\section{Paleoindian Period}

The Paleoindian period (11,200 to 8000 B.P.) spans the time of initial settlement to the advent of regional identities that mark the beginnings of later Archaic hunter-gatherers. These earliest groups, distinguished in the archeological record by various lanceolate points, including the Clovis, Folsom, Plainview, Golondrina, and Angostura types, are generally thought to have been small, highly mobile bands relying on large game animals for their basic livelihoods. Although a fairly large number of diagnostic artifacts dating to this period have been recovered in south Texas, no clearly intact sites have been investigated in the region. Consequently, the nature of Paleoindian adaptations remains poorly understood, relying largely on inferences from better-studied sites in adjacent areas such 
as the Southern Plains, Lower Pecos, and Central Texas.

Clovis points mark the earliest identified Paleoindian groups in the region. In a survey of fluted points reported from throughout the state, Meltzer and Bever (1995) identified 49 Clovis points from the South Texas region. Two trends are evident in their findings. First, Clovis points are rare in the coastal areas, including the Rio Grande delta (Pharr District). A total of 2 points were reported from the Pharr District counties (see Meltzer and Bever 1995:49-50). The 4 Clovis points recovered from the Corpus Christi District further substantiate the rarity of these early sites along the coast. Second, the vast majority of Clovis points in South Texas have been recovered from the inland plains of the Nueces, San Antonio, and Guadalupe basins, which includes most of the San Antonio District and part of the Laredo District. Thirtytwo points have been reported from the San Antonio District counties, and 11 are from the Laredo District. Although some of the points in these districts originated from the Edwards Plateau or Rio Grande basin, the distribution indicates that Clovis groups focused on the inland plains in the South Texas region.

Folsom point distributions, both the frequency and spatial patterning, differ from the Clovis patterns suggesting a shift in adaptations (Meltzer and Bever 1995:60, 74). Folsom points appear more frequently in the coastal plains as well as the inland plains. As Folsom points are almost exclusively found in plains settings (they are conspicuously lacking in the Edwards Plateau), the technology perhaps marks a more specialized adaptation, likely to a more-intensive reliance on bison.

Later Paleoindian points are also common in the region, but no intact sites dating to these times have been systematically studied in South Texas. The nearest sites with reasonably good integrity are located in the Lower Pecos (e.g. Baker Cave, Hinds Cave, Devil's Mouth, and Eagle Cave), the Coastal Plain (e.g., Berger Bluff, Berclair Terrace [also known as Buckner Ranch], and several sites in Victoria County), and Central Texas (e.g. Pavo Real, Gault).

The early lithic technology of the Paleoindians consisted mainly of the fluted projectile points and specialized blade core production (Hester 1995). At the later end of this period, projectile point styles change to nonfluted, lan- ceolate types such as Angostura and Golondrina (Black 1989a:49). In addition, the poorly dated Lerma dart point has been tentatively assigned to this period (Epstein 1969; MacNeish 1958; Suhm et al. 1954), but the continuing lack of corroborating data makes this style increasingly suspect as a legitimate type (Hester 1995). The important transitional stage between the Paleoindian period and the subsequent Early Archaic period is poorly understood in this region. However, it is believed there was a transition from big-game hunting to generalized hunting (Black 1989a). An accompanying technological shift from lanceolate points to stemmed dart points appears to have also occurred.

\section{Archaic Period}

Most of the archeological evidence from this period derives from investigations at Chaparrosa Ranch in Zavala County, Choke Canyon in Live Oak and McMullen Counties, Chacon Creek in Zavala and Uvalde Counties, the Falcon Reservoir area in Zapata and Starr Counties, and the Laredo area in Webb County. Additionally, numerous isolated studies fill in gaps to present a relatively broad set of data. Much of the recent work has been conducted in the border counties, where increased international commerce has supported numerous infrastructure improvements (e.g., roads, border crossings).

Early Archaic (8000 to 4500 B.P.) populations appear to have shifted subsistence practices towards an increased reliance on plant food resources and small game (Black 1989a:49). Early Archaic artifacts found in the region are triangular and stemmed projectile points found throughout South Texas and adjacent areas of northern Mexico. For the Early Archaic period, Hester (1995) distinguishes between the "Early Corner Notched Horizon" consisting of Martindale-Uvalde-Baker point types and the later "Early Basal Notched Horizon" consisting of Andice and Bell point types. Cultural materials from this period indicate an increased use of stone-lined hearths and the probable exploitation of terrestrial and aquatic food resources. Sites are generally found on high terraces or upland areas. However, as with the Paleoindian period, Early Archaic sites and materials are uncommon, and this period of human occupa- 
tion is presently poorly understood (Black 1989a).

Middle Archaic period (4500 to 2400 B.P.) sites are much more common, and they seem to occur in a much broader range of topographic settings. The Middle Archaic is interpreted to have been a period characterized by population increases, an expansion of lithic technologies, and more-intensive utilization of plant food resources. Larger, compacted hearths and ground stone tools are believed to indicate increased utilization of plant foods (Black 1989a). Dart points, unifacial scrapers, and preforms found at Middle Archaic sites suggest hunting and manufacturing activities. Gouges are present in artifact assemblages in increased numbers over the preceding period, possibly suggesting increased wood- or hide-working activities (Hester 1995). The appearance of projectile point types typical of other regions and marine shells originating from outside the area suggest an expansion of trade or exchange networks. Burial of the dead in cemeteries appears to have been more common in this period as evidenced by excavations at the Loma Sandia site in Live Oak County (Taylor and Highley 1995). Dart points from this period consist of the Tortugas, Abasolo, Carrizo, and Bulverde types. However, as discussed below, the unstemmed points are fairly ambiguous chronological markers.

The Late Archaic period (2400 to 1200 B.P.) represents a continuation of trends begun in the Middle Archaic, mainly increasing population and intensive exploitation of the environment. Late Archaic sites are common throughout South Texas in all topographic settings. The presence of large cemeteries along the coast and eastern portions of South Texas suggest increased population densities for this period (Black 1989a). As with the preceding period, populations in the Late Archaic exploited plant food resources, small game, and aquatic resources. Unstemmed dart points of the Matamoros and Catan types have commonly been considered diagnostic artifacts of the Late Archaic, although a number of studies (e.g., Shiner 1983) have questioned the utility of the types. A recent study by Mahoney et al. (2002) indicates these are neither viable types nor chronological markers. Distinctions between the Matamoros and Tortuga and the Abasolo and Catan types cannot be clearly defined, and the styles are in fact parts of a continuum in size with no discernible temporal distinctions. Another point type from this period is Shumla, which is somewhat better defined based on studies in the Lower Pecos area.

\section{Late Prehistoric Period}

The Late Prehistoric period (1200 to 400 B.P.) is marked by two technological innovations, ceramics and the bow and arrow. Prehistoric sites from this period are often the best preserved, most distinctive, and most visible of all periods in South Texas. Ceramics are generally bone or sand tempered. Late Prehistoric settlement patterns suggest increased mobility, perhaps an effect of greater reliance on bison as a subsistence mainstay. Faunal assemblages show an increased consumption of bison, deer, and antelope (Black 1989a). At the Hinijosa site in Jim Wells County, the well-preserved faunal remains associated with a Toyah occupation showed a dependence on deer and antelope and, to a lesser extent, bison (Black 1986). Adoption and use of the bow and arrow may have facilitated the shift in balance between animal and plant foods. In South Texas, common arrow point types include Perdiz, Scallorn, Fresno, Starr, and Zavala.

\section{Historic Period}

The early phase of the Historic period included Spanish exploration and expansion into South Texas, colonization of areas along the Rio Grande, and the attempted missionization of the local Native American groups. In 1519, Alonso de Pineda, sailing on behalf of conquistador Francisco Garay, first charted the South Texas coastline, discovering the mouth of Rio de las Palmas (Rio Grande). Pineda camped along the river delta for 40 days, reporting to Garay about the area's promise for settlement (Sanchez 1992:53). Garay subsequently supported two attempts to establish a settlement in the Rio Grande delta, but both were thwarted by hostile natives and the inhospitable landscape. Following these first entries into Texas, in 1535, after living seven years among the Texas coastal inhabitants, Cabeza de Vaca and several other castaways from Narvaez's ill-fated expedition crossed along the northern margin of the region on their journey back to Spanish colonies in Mexico. His account of the ordeal 
provides some of the more-detailed information on the area and its native inhabitants.

The chroniclers of these expeditions and others and early missionaries provide descriptions of the native groups in South Texas at the time of contact. Their accounts defined the groups in northeast Mexico as Coahuileños. From the recorded fragments of the language of these groups, Mexican linguists defined the Coahuilteco language in the 1860s, and later researchers constructed the larger Coahuiltecan linguistic family, which was surmised to include the language of groups throughout the northeast Mexico-South Texas region. Although some (i.e., Newcomb 1961; Ruecking 1953, 1955a, 1955b;) have proposed a broad Coahuiltecan culture as well as a linguistic grouping, "this belief in a widespread linguistic and cultural uniformity was [later] seriously questioned" (Campbell 1983:343). Recent research has perhaps substantiated this notion. For example, Johnson and Campbell (1991) defined the previously unidentified Sanan language among mission Indians in the region. In part, there was perhaps a rush to judgment in defining a "monolithic adaptation" that led to an oversight in variability.

Nevertheless, the ethohistorical record suggests some commonalities among the groups in the region. All were nomadic hunter-gatherers who moved around the landscape exploiting seasonal foods (Campbell and Campbell 1981), most likely within clearly defined territories. Griffen (1969:115) cites a number of early descriptions of highly mobile groups moving within clearly recognized and marked areas. Alonso de Leon, observing groups south of the Rio Grande in 1689 , describes the social organization and settlement patterns that were commonly noted elsewhere in the region. He describes two distinct groupings using terms familiar to his own society: the rancheria and rancho. The former is a larger group, presumably the band. Based on ethnographic accounts of groups in northeastern Mexico, Griffen (1969:115) infers an average band size of 40 to 60 persons with recorded variations ranging from roughly 25 to 75 individuals. These rancherias often comprised about 15 bell-shaped huts arranged in rows or a crescent formation. Each house contained a central fire said to be used mainly for illumination (Campbell 1983:51). As described by De Leon, the smaller group, occupying the rancho, was a family unit. When not in the larger groupings, "each family ...or two together travel around the hills, living two days here and four there" (De Leon as cited by Griffen 1969:115). In addition to these groupings, sources often refer to a larger group, a nation. This group is the largest identity, but it is unclear if this level of organization was ever a viable political entity until later ethnohistorical times, when regional groups united to confront colonial advancement and decimation. From the early seventeenth century to the nineteenth century, increased pressures from southward territorial expansion by the Apaches and Comanches and northward Spanish expansion destroyed these indigenous groups.

\section{COASTAL BEND AND CENTRAL COASTAL PLAIN}

This synopsis focuses on the Corpus Christi District and southeast margin of the San Antonio District. Many people, institutions, and governmental agencies have undertaken archeological investigations on the central coastal plain of Texas. Among the more prominent of these are excavations by The University of Texas at Austin and the Works Progress Administration at the Johnson and Kent-Crane sites in the Copano Bay and Aransas Bay areas (Campbell 1947, 1952); Story's (1968) excavations at the Ingleside Cove and Anaqua sites in San Patricio and Jackson Counties; excavations at 41AU37 and 41AU38 along Allen's Creek in southern Austin County by The University of Texas at Austin (Hall 1981); excavations by the University of Texas at San Antonio (UTSA) at the Hinojosa site situated approximately $60 \mathrm{~km}$ inland from Corpus Christi Bay (Black 1986); explorations by the Texas Historical Commission in the projected area of Palmetto Bend Reservoir along the Lavaca and Navidad Rivers of Jackson County (Mallouf et al. 1973); UTSA survey and site testing in the area of Coleto Creek Reservoir in Victoria and Goliad Counties (Fox and Hester 1976; Fox et al. 1979); extensive survey and excavation efforts, primarily by UTSA, at Choke Canyon Reservoir in Live Oak and McMullen Counties (Brown et al. 1982; Hall et al. 1982, 1986; Highley 1986); excavations by the Texas Department of Transportation (TxDOT) at the Loma Sandia site in Live Oak County and subsequent analysis by The 
University of Texas at Austin (Taylor and Highley 1995); TxDOT-sponsored excavations by UTSA at Mission Nuestra Señora del Refugio in Refugio County (Jantz et al. 2002; Tennis 2002); Robert A. Ricklis's (1988, 1989, 1995, 1996) work at the Holmes and McKinzie sites, among others, in the Corpus Christi and Copano Bay area; testing and data recovery excavations at sites along the Victoria Barge Canal in Victoria and Calhoun Counties, much of which has not yet been published (Gadus et al. 1999; Weinstein 1992); and recent work by the Texas Historical Commission at La Salle's Fort St. Louis and the first location of Presidio La Bahía (Bruseth and Durst 2002; Davis and Bruseth 2000, 2001; Davis et al. 2000), as well as work at other Spanish Colonial Missionperiod sites (Calhoun 1999; Hindes et al. 1999; Ricklis 1999; Walter 1999). Summaries of the prehistory of the region based on these investigations, and more complete bibliographies concerning previous work, have been compiled by Black (1989a), Weinstein (1992), Hester (1995), Ricklis (1995), and Tomka et al. (1997).

\section{Paleoindian Period}

The earliest occupation of the coastal plain occurred in the Paleoindian period ca. 11,000 to 8,000 years ago. The first half of this period is marked by the occurrence of Clovis and Folsom dart points, almost always in isolated contexts. For instance, a Clovis point was recovered from San Patricio County near the mouth of the Nueces River (Hester 1976), and a Folsom point was recovered on Oso Creek (Hester 1980:6). Excavated Paleoindian components on the coastal plain include the deep terrace sites of Buckner Ranch located in Bee County, the Berger Bluff site in Goliad County, and the Johnston-Heller and J-2 Ranch sites in Victoria County. The Buckner Ranch site produced late Pleistocene fauna and hearth-like clusters of burned rocks, as well as Folsom, Plainview, Scottsbluff, and Angostura points (Sellards 1940). Hester (1976:8-9), in a reevaluation of Sellards's data, concluded that the site "served as a campsite for a succession of Paleo-Indian groups" possibly spanning 3,000 years. Though this site is the only one of the excavated components to produce a Folsom point, in a more recent discussion Hester (1995:434) states "no Folsom camps or kill sites have been located."
Late Paleoindian points such as Plainview and Golondrina have been recovered from the Johnston-Heller site and the J-2 Ranch site (Birmingham and Hester 1976; Fox et al. 1979). Clear Fork tools also were recovered at the Johnston-Heller site. The Berger Bluff site, now inundated by Coleto Creek Reservoir, produced a deeply buried hearth dated to ca. 8,000 to 6,000 years ago. This site is of interest because its faunal assemblage includes small animals not thought to be characteristic of a Paleoindian biggame subsistence pattern (Brown 1996:497-498; Weinstein 1992:60). Investigation of these components indicates the earliest Americans' longlived, slowly changing adaptation to the near-coast.

Evidence of Paleoindian use of the coastal zone also comes from isolated finds in eroded or disturbed contexts. The erosion is in part the result of a dramatic sea level change associated with the end of the last glaciation. At that time, sea level was much lower than today, and the Gulf shoreline was appreciably farther south of its present position (Aten 1983:117, 146). As sea level began to rise, it likely inundated many Paleoindian sites. Both artifacts and fossil bones have been recovered from Texas beaches and are believed to be eroding from submerged, relict deltaic landforms that contain these ancient sites. One such area that has produced artifacts and fossil bones is 41MG4, the Sargent Beach site. The site produced one late Paleoindian Angostura point, as well as Archaic Pedernales and Kent points and fossil bones, including horse, bison, and mammoth teeth. Fossil bones and teeth of mastodon, mammoth, bison, horse, camel, deer, and turtle without associated artifacts have been recovered from several nearby disposal areas for dredged materials along the Gulf Intracoastal Waterway west of the San Bernard River (Black and Cox 1983) and to the south in alluvium of the ancestral Palo Blanco River of northern Kenedy County (Shum 1980).

\section{Archaic Period}

Toward the end of the Paleoindian period, a disruption in large game populations may have precipitated a greater reliance on a broad-based subsistence strategy (Aten 1983:152-157). This presumed but probably overstated change in subsistence strategy has been used to mark the beginning of the Archaic period. There also is 
evidence of climatic fluctuations and additional episodes of sea level rise within this period. These fluctuations have been used to divide the Archaic into early, middle, and late subperiods.

The Early Archaic spans the period from 8000 to 5000 B.P. when sea level was still well south of its present location (Aten 1983:117). As with Paleoindian sites, few Early Archaic sites are known, and it has been suggested that populations and site densities continued to be low on the entire coastal plain (Story 1985:37). Projectile points diagnostic of the period include Gower, Wells, Bell, Andice, Martindale, Uvalde, and related forms (Black 1989a:49; Weinstein 1992:57). Inland along the edge of the coastal plain, sites are associated with upland landforms and high terraces, though several components within deep alluvium are known from the Choke Canyon area of Live Oak County (Scott and Fox 1982). Examples of sites from the coastal bend include 41VT17 (Fox and Hester 1976), the McKenzie site (Ricklis 1988), and the Swan Lake site (Prewitt et al. 1987). Though the Early Archaic components at these sites are ephemeral, they demonstrate early use of the estuarine bay shore environment. During the late part of the Early Archaic, the number of coastal components increased, as did the intensity of the occupations. It appears that both shellfish and fish were exploited to the extent that these early components likely functioned as fishing camps (Ricklis 1988:101-102, 1995: 272-278).

The coastline reached its present position in the Middle Archaic, which lasted from 5000 to 3000 B.P., with the climate approaching modern conditions at the end of the period (Aten 1983:137, 316; Story 1990:244). It has been suggested that these changes may have enhanced coastal resources enough that populations and site densities increased (Story 1985:39, 1990:244). Toward the end of this period, extensive shell middens appeared, signaling that the bays and estuaries had developed to the extent that shellfish had become a ubiquitous resource. On the coast in Aransas and Nueces Counties, this intensive exploitation of estuarine resources was first given the appellation Aransas focus (Campbell 1947, 1952). Distinctive shell tools such as Busycon whorl scrapers and columella gouges mark Aransas sites. Similar tools have been recovered from shell midden sites as far north along the coast as Lavaca Bay and the lower reach of Caney Creek in Matagorda County (Fritz 1975:129).

To tighten the chronological and spatial parameters for this archeological manifestation, the Aransas complex was defined for the Late Archaic period based on work at the Kent-Crane site (Campbell 1958; Corbin 1974). The Middle Archaic manifestation has been labeled the Kent phase (Weinstein 1992:61). Projectile points including Matamoros, Bulverde, and Palmillas mark this phase. Other Middle Archaic period projectile points with inland ties include Morhiss, Nolan, Travis, and Refugio (Black 1989a:49; Weinstein1992:61).

In the inland southern part of the region, data from the Choke Canyon Reservoir sites suggest that open camps along stream courses on natural levees and low terraces marked the Middle Archaic period. Features such as formal hearths, earth ovens, and concentrations of burned rocks point to an emphasis on the use of plant resources (Hall et al. 1986). Possible baking pit features with associated concentrations of burned rocks also have been identified at coastal shell midden sites. One such Middle Archaic shell midden, 41CL9 situated in Calhoun County along the upper Guadalupe River estuary, also produced faunal data indicating that terrestrial resources contributed significantly to the coastal resource base (Gadus et al. 1999:3573).

The Late Archaic period, which dates from ca. 3000 to 1250 B.P., is marked by a continuation and intensification of Aransas adaptations on the coast. Some sites, such as Mustang Lake on San Antonio Bay and Ingleside Cove on Corpus Christi Bay, produce faunal data that suggest intensive fishing (Ricklis 1995:281280 ). Inland, the presence of grinding implements and large deposits of burned rocks at the Choke Canyon sites suggest continued, intensive exploitation of plant resources (Hester 1995:441). Point types found on the coast include Ensor, Darl, and Fairland. Inland point types for this period include Frio, Marcos, Montell, Morhiss, Castroville, and Ellis (Black 1989a:51; Weinstein 1992:57). Overall, this period saw a continued increase in populations and trend toward defined territories (Story 1985:44-45, 48).

One indication of population increase is the expansion of formal cemeteries. Cemeteries appeared in the Middle Archaic period and grew in size and number though the Late Archaic and 
into the Late Prehistoric period (Hall 1995a:5657). An extensive Middle Archaic through Late Prehistoric period cemetery has been excavated at Allen's Creek (Hall 1981). The site, 41AU36, is located on the Brazos River approximately $115 \mathrm{~km}$ north of the coast in Austin County. Burials showed an increase in traumatic deaths, specifically during the Late Archaic period, that might be considered evidence of a boost in hostilities suggesting greater territorial competition (Hall 1981:284-285). Closer to the coast, the Blue Bayou cemetery (41VT94) and the Morhiss cemetery (41VT1) are situated on the lower reach of the Guadalupe River in Victoria County (Campbell 1976:81-85; Huebner 1988). The Morhiss cemetery has been dated to the Archaic period by diagnostic projectile points recovered from the associated habitation site. Because shell ornaments and many lithic materials were recovered from the habitation site, investigators have suggested that the inhabitants had both inland and coastal interactions (Hall 1995a:49-50). Similar interactions can be suggested from the grave goods at the inland formal cemetery at the Loma Sandia site in Live Oak County (Taylor and Highley 1995), although the people who occupied Loma Sandia apparently interacted more regularly with groups on the Rio Grande Plain to the south (Hall (1995b:645-646). These suggested differences in interaction provide data needed for understanding territorial affiliations across the coastal plain.

\section{Late Prehistoric Period}

The Late Prehistoric period began variously along the Texas coastal plain at ca. 1700 to 1250 B.P. It was marked by the addition of pottery and the bow and arrow to an otherwise Archaic technological repertoire (Aten 1983:297-304; Corbin 1976:91; Weinstein 1992:57). Scallorn arrow points, one of the earliest forms found on the coast, have been recovered from burials at the Blue Bayou site dating to the early Late Prehistoric, ca. A.D. 430-990 (Huebner 1988). Scallorn points and expandingstem arrow point forms also were recovered from more-inland sites such as the Berger Bluff site located in Goliad County (Brown 1983) and sites in the Choke Canyon area of Live Oak County (Hall et al. 1986). In many cases, no ceramics were associated with these components, suggest- ing separate arrival or development of the two technologies. Similarities of these components to the early Late Prehistoric Austin phase components of central Texas have been acknowledged (Brown 1983: 80-81; Weinstein 1992:63).

Slightly later but before A.D. 1000, bonetempered ceramics and expanding-stem arrow points are known from the Choke Canyon sites (Black 1989a:52), and Scallorn points and sandy paste ceramics like ceramics from the upper Texas coast appeared on the central coast. Scallorn points and sandy paste ceramics were recovered from the Anaqua site and other sites located along the lower Lavaca and Navidad Rivers in Jackson County (Mallouf et al. 1973:136; Story 1968), as well as the Kent-Crane site in Aransas County (Cox and Smith 1988). Weinstein (1992:64) suggests that these components are recognizable cultural manifestations that preceded introduction of Rockport ceramics along the south and central coasts.

Rockport ceramics, a sandy paste ware decorated with asphalt designs and incising, occur most often with Perdiz and Fresno points. Other arrow point types occasionally found include Starr, Padre, Scallorn, Young, Cliffton, and McGloin (Corbin 1974:43). The occurrence of these artifact types along the coast-generally in Kleberg, Nueces, San Patricio, Aransas, and Refugio Counties-has been used to define the Rockport phase of the Late Prehistoric-Historic period (Campbell 1952, 1958; Story 1968; Suhm et al. 1954). The Rockport phase has been linked to the historically known Karankawa Indians because that group continued to produce the distinctive asphalt-decorated and asphaltcoated ceramics well into historic times.

Archeological studies of prehistoric and historic Karankawa adaptive strategies suggest that these people took advantage of both coastal estuarine and adjoining prairie-riverine resources. Based on sites in the Corpus Christi Bay and Copano Bay area, Ricklis (1996:100124) discerned a seasonal pattern in the occupation of coastal and nearby inland sites that may reflect this strategy. Two Late Prehistoric site types have been identified. One is a shoreline fishing camp that has extensive deposits of estuarine resource remains, and the other is an inland hunting camp with large quantities of terrestrial game such as deer and bison (Ricklis 1996:33). Seasonal data based on fish otoliths and Rangia cuneata samples indicate that the 
fishing camps were occupied in the fall through winter or early spring and that hunting camps were occupied in the spring and summer (Ricklis 1996:70-71, 89-95). In this model, fishing camps were occupied at a time of year when a reliable resource - that is, fish — was concentrated along the coast and allowed people to mass. Concomitantly, hunting camps represent population dispersal geared toward more-scattered resources-bison and deer. How far inland the Karankawa may have journeyed on their seasonal round and what interactions they may have had with inland-based groups are questions that require additional research.

Though the Karankawa may have moved inland seasonally to hunt bison and deer, faunal evidence from Hinojosa site in Jim Wells County and the Choke Canyon sites suggests that resident inland groups may have focused both on large game and a wide range of smaller animals (Steele 1986; Steele and Hunter 1986). Recognition of a related lithic tool kit emphasized the importance of large game such as bison to the subsistence base (Black 1989a:53-54). Consisting of Perdiz arrow points, small end scrapers, and beveled knives, this tool kit has been linked to the Toyah phase cultures that appear to have originated on the Southern Plains and moved south to central Texas, probably in response to southward-expanding bison herds (Black 1989a:57). The Toyah phase tool kit has been identified at the Hinojosa site and is often found within Rockport phase sites on the central coast (Black 1986:254-255; Ricklis 1995:285, 287). But the mechanisms behind adoption of this Toyah technology and its meaning for the coastal and near-coastal peoples have yet to be clearly defined (see Johnson [1994] for a wide-ranging discussion of the Toyah culture).

\section{Historic Period}

The first encounter between aboriginal groups of the Central Coastal Plain and Europeans occurred when Spanish shipwreck survivor and eventual trader Alvar Nuñez Cabeza de Vaca lived and traveled with various groups ca. 1528 (Hester 1999:17-19). Reestablishing Cabeza de Vaca's movements places him on the Texas coast in the vicinity of San Antonio, Copano, and Corpus Christi Bays (Campbell and Campbell 1981:2-9). The Karankawa also met Robert Sieur de La Salle on his fateful expedi- tion that ended along Matagorda Bay in the winter of 1685 (Ricklis 1996:1,112). Recent work at the site of La Salle's Fort St. Louis (41VT4) and the excavation of La Salle's ship, the Belle, in Matagorda Bay will provide new information on this contact and the lives of the Frenchmen who participated in that expedition (Bruseth and Durst 2002; Davis and Bruseth 2000; Davis et al. 2000). The French presence on the Texas coast was short, but the Spanish, with their emphasis on establishing missions and presidios, had a lasting effect.

Spanish attempts to establish missions and presidios along the coastal plain continued through the 1700s. These included Mission Espíritu Santo, established in 1722 in the present vicinity of Jackson County and then moved to Victoria County in 1726; Presidio La Bahía and Mission Rosario, established in 1749 and 1754 in Goliad County; and Mission Nuestra Señora de Refugio, first located in Calhoun County and then moved to Refugio County in 1795 (Ricklis 1996:145). Recent investigations of some of these sites, especially the work by TxDOT and UTSA at Mission Refugio and Ricklis's excavations at Missions Espíritu Santo and Nuestra Señora del Rosario, have provided important information on mobility patterns, diet, technologies, economic activities, acculturation, demographic patterns, health, and interactions between the Spanish and $\mathrm{Na}$ tive Americans (Calhoun 1999; Jantz et al. 2002; Ricklis 1999; Tennis 2002; Walter 1999). These investigations, as well as work on Late Prehistoric and historic aboriginal sites, appear to indicate that coastal aboriginal groups kept their ethnic identities despite attempts by the Spanish to missionize them and to some extent they fit the mission system into their aboriginal subsistence pattern (Ricklis 1996:159-168). Consequently, local coastal Native American groups, such as the Karankawa, survived as much-reduced but viable groups into the nineteenth century. Native groups did not, however, survive the aggressive Anglo-American settlement of the Texas coast that took place during the nineteenth and twentieth centuries.

\section{LOWER PECOS}

The northwestern portion of the Laredo District, namely Val Verde County, lies in the Lower Pecos archeological region as it is typically 
delineated (see for example Bement 1989; Turpin 1991, 1995). One of the hallmarks of the region's archeology, dry rockshelter and cave sites, has preserved art and perishable materials generally lost in more-mesic settings. Accordingly, the prehistoric material assemblage is perhaps the most comprehensive in the state. The following chronology divides the regional chronology into Paleoindian, Archaic, Late Prehistoric, and Historic periods, subdivided into more specific subperiods as discussed by Turpin (1991, 1995), who draws on a long tradition of chronology building in the Lower Pecos and numerous radiocarbon dates.

\section{Paleoindian Period}

The Paleoindian period (14,500 to 8800 B.P.) spans the Pleistocene-Holocene transition, a time of relatively rapid climatic, floral, and faunal changes. The Aurora and subsequent Bonfire subperiods are represented most notably in Cueva Quebrada (Lundelius 1984) and Bonfire Shelter (Bement 1986; Dibble and Lorrain 1968), where cultural deposits are associated with the remains of extinct species such as camel, elephant, horse, and Bison antiquus. The earliest subperiods are the hallmark of the stereotypical Paleoindian adaptation, a subsistence strategy focused on large game. The late Paleoindian subperiod Oriente shows the gradual transition to an Archaic lifestyle as the climate became drier. Much of the evidence for the paleoenvironmental changes derives from studies conducted in 1970 s and 1980 s, when a theoretical shift toward an ecological approach made the Lower Pecos an appealing research area because of excellent preservation of floral and faunal remains. Notable among the studies, Texas A\&M University carried out paleoenvironmental research at Hinds Cave (Shafer and Bryant 1977), and The University of Texas at San Antonio worked at Baker Cave (Brown 1991; Chadderdon 1983; Hester 1983).

\section{Archaic Period}

The long Archaic period (9000 to 1300 B.P.) is divided into six subperiods. This relatively precise chronology was defined by data recovered primarily from dry rockshelters and caves. Before addressing the Archaic chronology, a brief account of the history of investigations is pro- vided here, in part to note the extensive amount of evidence collected from the region. The earliest excavations-conducted under the auspices of the Smithsonian Institution, The University of Texas at Austin, and the Witte Museum-began in the 1930s. Among the more notable early studies were a number of cave excavations and several works on the area's rock art. Pearce and Jackson's (1933) excavation of Fate Bell Shelter along Seminole Canyon inaugurated a rapid succession of rockshelter investigations, which included study of Shumla, Eagle, Moorhead, and Murrah caves, among others. Information collected from these provided a basis for the first chronologies and trait lists proposed by Sayles (1935) and Kelley et al. (1940). Forrest Kirkland (1937, 1938, 1939) and A. T. Jackson (1938) undertook documentation of the regional rock art. Later rock art studies over the last two decades (Shafer 1977, 1986; Turpin 1982, 1984, 1986a, 1986b, 1990; Zintgraff and Turpin 1991) have further tapped into the interpretive, chronological, and aesthetic potentials of these symbols.

Following the early studies, work resumed in the 1950s and continued through the 1960s during the reservoir salvage years. To mitigate the effects of the proposed Amistad Dam and Reservoir, originally designated Diablo Reservoir, the Archeological Salvage Program was established under the directorship of E. B. Jelks at The University of Texas in Austin. The reservoir study provided auspices for surveys (e.g., Graham and Davis 1958; Parsons 1962; Taylor 1958; Taylor and Rul 1961), rockshelter and cave excavations (e.g., Alexander 1970; Dibble 1965, 1967; Epstein 1960, 1963; Nunley et al. 1965; Parsons 1965; Prewitt 1966), terrace site excavations (e.g., Johnson 1964), and rock art recording (e.g., Gephard 1960, 1965; Grieder 1965; Parsons 1962). As the new studies added to earlier efforts, a revitalized interest in works of the previous generation led to a number of syntheses and reassessments, notably those of Kirkland and Newcomb (1967), and Shuetz $(1956,1961,1963)$.

The Archaic is usually defined by a generalized subsistence pattern marked by intensification in the exploitation of locally available resources and the rise of territoriality, or regionality. Burned rock middens, various ground stone features and artifacts, and the proliferation of spatially specific artifact styles are indicators of these trends. The Viejo 
subperiod, the earliest in this period, coincided with a widespread drying trend. Fiber artifacts, coprolite analysis, and other lines of evidence indicate an advanced adaptation to the arid conditions. The subsequent Eagle Nest and San Felipe subperiods show increasing intensification in resource exploitation, insularity, and possibly internal social stresses. In the latter of these two subperiods, rock art flourished on a grand scale, the polychromatic Pecos River style. With the return of bison to the area, an abrupt change in the cultural trajectory is noted during the Cibola subperiod. Broad-bladed dart points and a stylistic change in rock art reflect the fundamental shift. The following Flanders subperiod is perhaps a return to a desert adaptation reminiscent of the earlier Archaic times, but the archeological record is rather inconclusive. The final Archaic era, the Blue Hills subperiod, shows a gradual transition to the Late Prehistoric. Though a desert adaptation is still evident, stylistic affinities suggest participation in a larger interaction sphere extending into central Texas and beyond.

\section{Late Prehistoric Period}

The Late Prehistoric period includes the Flecha and subsequent Infierno subperiods. Along with new technologies such as the bow and arrow, most aspects of culture, including subsistence patterns, site types, artifact styles, mortuary practices, and artistic expression, changed during this period. The Red Monochrome and Bold Line Geometric art styles appear to have entered the area fully developed (Turpin 1995:550-553). In the final stages of this period, ominous effects of far-away changes begin to trickle into the cultural setting. Disease and societies marginalized by the advancing frontier ruptured a long continuity in the cultural trajectory.

\section{Historic Period}

The Historic period began with the first Spanish entradas in the sixteenth and seventeenth centuries. Gaspar Castano de Sosa reportedly crossed the Rio Grande near present-day Del Rio in 1590 en route to Pecos pueblo. In 1720, Berroteran with a band of 70 soldiers marched along the left bank of the Rio Grande from present-day Langtry to Dryden
(Tyler 1996:32). In 1736, Garza Falcon led an expedition into the area, intending to confront hostile groups and find a site to establish a presidio for frontier defense. Though no tribes submitted themselves for a thrashing, Falcon identified a suitable presidio site on which Presidio Sacramento, later designated Agua Verde, was established in 1738.

\section{SOUTHEAST MARGIN OF CENTRAL TEXAS}

The archeological record of the Central Texas region is known from decades of investigations of stratified open air sites and rockshelters throughout the Edwards Plateau, its highly dissected eastern and southern margins, and the adjoining margins of physiographic regions to the east and south (see Collins [1995] for review). Thus, traditionally the Central Texas archeological area has included the northern part of the San Antonio District (e.g., Prewitt 1981; Suhm 1960). This part of the study area is on the periphery of the Central Texas area, though, and its archeological record suggests influences from and varying degrees of contact over time with other areas such as the Lower Pecos and Gulf Coastal Plain (Collins 1995; Johnson and Goode 1994). Archeological sites in the San Antonio District that have contributed important information include the Richard Beene site at Applewhite Reservoir (McGraw and Hindes 1987; Thoms and Ahr 1996; Thoms and Mandel 1992), the Cibolo Crossing site at Camp Bullis (Kibler and Scott 2000), the Panther Springs Creek site in Bexar County (Black and McGraw 1985), the Jonas Terrace site in Medina County (Johnson 1995), the Camp Pearl Wheat site in Kerr County (Collins et al. 1990), 41BX1 in Bexar County (Lukowski 1988), 41BX300 in Bexar County (Katz 1987), and several sites at Canyon Reservoir (Johnson et al. 1962). For more-complete bibliographies concerning archeological work done in the region, see Black (1989b), Collins (1995), and Johnson and Goode (1994).

\section{Paleoindian Period}

Surficial and deeply buried sites, rockshelter sites, and isolated artifacts represent Paleoindian (11,500-8800 B.P.) occupations of the Central Texas region. The period is often 
described as having been characterized by small but highly mobile bands of foragers who were specialized hunters of Pleistocene megafauna. But Paleoindians probably used a much wider array of resources (Meltzer and Bever 1995:59), including small fauna and plant foods. Faunal remains from Kincaid Rockshelter and the Wilson-Leonard site (41WM235) support this view (Bousman 1998; Collins 1998; Collins et al. 1989). Longstanding ideas about Paleoindian technologies also are being challenged.

Collins (1995) divides the Paleoindian period into early and late subperiods. Two projectile point styles, Clovis and Folsom, are included in the early subperiod. Clovis chipped stone artifact assemblages, including the diagnostic fluted lanceolate Clovis point, were produced by bifacial, flake, and prismatic-blade techniques on high-quality and oftentimes exotic lithic materials (Collins 1990). Along with chipped stone artifacts, Clovis assemblages include engraved stones, bone and ivory points, stone bolas, and ochre (Collins 1995:381; Collins et al. 1992). Clovis points are found evenly distributed along the eastern edge of the Edwards Plateau, where springs and outcrops of chert-bearing limestone are common (Meltzer and Bever 1995:58). Sites within the area yielding Clovis points and Clovis-age materials include Kincaid Rockshelter (Collins et al. 1989), Pavo Real (Henderson and Goode 1991), and San Macros Springs (Takac 1991). A probable Clovis polyhedral blade core and blade fragment were found at the Greenbelt site in San Antonio (Houk et al. 1997). Analyses of Clovis artifacts and site types suggest that Clovis peoples were welladapted, generalized hunter-gatherers with the technology to hunt larger game but not rely on it solely. In contrast, Folsom tool kits-consisting of fluted Folsom points, thin unfluted (Midland) points, large thin bifaces, and end scrapers-are more indicative of specialized hunting, particularly of bison (Collins 1995:382). Folsom points have been recovered from Kincaid Rockshelter (Collins et al. 1989) and Pavo Real (Henderson and Goode 1991).

Postdating Clovis and Folsom points in the archeological record are a series of dart point styles (primarily unfluted lanceolate darts) for which the temporal, technological, and cultural significance is unclear. Often, the Plainview type name is assigned these dart points, but Collins (1995:382) has noted that many of these points typed as Plainview do not parallel Plainview type-site points in thinness and flaking technology. Investigations at the Wilson-Leonard site (see Bousman 1998) and a statistical analysis of a large sample of unfluted lanceolate points by Kerr and Dial (1998) have shed some light on this issue. At Wilson-Leonard, the Paleoindian projectile point sequence includes an expanding-stem dart point termed Wilson, which dates to ca. 10,000-9500 B.P. Postdating the Wilson component is a series of unfluted lanceolate points referred to as Golondrina-Barber, St. Mary's Hall, and Angostura, but their chronological sequence is poorly understood. Nonetheless, it has become clear that the artifact and feature assemblages of the later Paleoindian subperiod appear to be Archaic-like in nature and in many ways may represent a transition between the early Paleoindian and succeeding Archaic periods (Collins 1995:382).

\section{Archaic Period}

The Archaic period for Central Texas dates from ca. 8800 to $1300-1200$ B.P. (Collins 1995) and generally is believed to represent a shift toward hunting and gathering of a wider array of animal and plant resources and a decrease in group mobility (Willey and Phillips 1958:107108). In the eastern and southwestern United States and on the Great Plains, development of horticultural-based, semi-sedentary to sedentary societies succeeded the Archaic period. In these areas, the Archaic truly represents a developmental stage of adaptation as Willey and Phillips (1958) define it. For Central Texas, this notion of the Archaic is somewhat problematic. An increasing amount of evidence suggests that Archaic-like adaptations were in place before the Archaic (see Collins 1995:381-382, 1998; Collins et al. 1989) and that these practices continued into the succeeding Late Prehistoric period (Collins 1995:385; Prewitt 1981:74). In a real sense, the Archaic period of Central Texas is not a developmental stage, but an arbitrary chronological construct and projectile point style sequence. Establishment of this sequence is based on several decades of archeological investigations at stratified Archaic sites along the eastern and southern margins of the Edwards Plateau. Collins (1995) and Johnson and Goode (1994) have divided this sequence into three parts-early, middle, and late-based on 
perceived (though not fully agreed on by all scholars) technological, environmental, and adaptive changes.

Early Archaic (8800-6000 B.P.) sites are small, and their tool assemblages are diverse (Weir 1976:115-122), suggesting that populations were highly mobile and densities low (Prewitt 1985:217). It has been noted that Early Archaic sites are concentrated along the eastern and southern margins of the Edwards Plateau (Johnson and Goode 1994; McKinney 1981). This distribution may indicate climatic conditions at the time, given that these environments have more-reliable water sources and a morediverse resource base than other parts of the region. Early Archaic projectile point styles include Hoxie, Gower, Wells, Martindale, and Uvalde. Clear Fork and Guadalupe bifaces and a variety of other bifacial and unifacial tools are common to Early Archaic assemblages. Construction and use of rock hearths and ovens, which had been limited during late Paleoindian times, became commonplace. The use of rock features suggests that retaining heat and releasing it slowly over an extended period were important in food processing and cooking and reflects a specialized subsistence strategy. Such a practice probably was related to cooking plant foods, particularly roots and bulbs, many of which must be subjected to prolonged periods of cooking to render them consumable and digestible (Black et al. 1997:257; Wandsnider 1997; Wilson 1930). Botanical remains, as well as other organic materials, are often poorly preserved in Early Archaic sites, so the range of plant foods exploited and their level of importance in the overall subsistence strategy are poorly understood. But recovery of charred wild hyacinth (Camassia scilloides) bulbs from an Early Archaic feature at the Wilson-Leonard site provides some insights into the types of plant foods used (Collins et al. 1998). Significant Early Archaic sites include the Richard Beene site in Bexar County (Thoms and Mandel 1992), the Camp Pearl Wheat site in Kerr County (Collins et al. 1990), and the Jetta Court site in Travis County (Wesolowsky et al. 1976).

During the Middle Archaic period (60004000 B.P.), sites increased in number, size, and distribution as population densities grew (Prewitt 1981:73; Weir 1976:124, 135). Macrobands may have formed at least seasonally, or more small groups may have used the same sites for longer periods (Weir 1976:130 131). Development of burned rock middens toward the end of the Middle Archaic suggest a greater reliance on plant foods, although tool kits still imply a considerable dependence on hunting (Prewitt 1985:222-226). Middle Archaic projectile point styles include Bell, Andice, Taylor, Baird, Nolan, and Travis. Bell and Andice points reflect a shift in lithic technology from the preceding Early Archaic Martindale and Uvalde point styles (Collins 1995:384). Johnson and Goode (1994:25) suggest that Bell and Andice darts are parts of a specialized bisonhunting tool kit. They also believe that an influx of bison and bison-hunting groups from the Eastern Woodland margins during a slightly more-mesic period marked the beginning of the Middle Archaic. Though no bison remains were recovered or present, Bell and Andice points and associated radiocarbon dates were recovered from the Cibolo Crossing (Kibler and Scott 2000), Panther Springs Creek, and Granberg II (Black and McGraw 1985) sites in Bexar County. Bison disappeared as more-xeric conditions returned during the late part of the Middle Archaic. Later Middle Archaic projectile point styles represent another shift in lithic technology (Collins 1995:384; Johnson and Goode 1994:27). Prewitt (personal communication 2000) postulates that the production and morphology of Travis and Nolan points are similar to projectile points from the Lower Pecos region. Because they appeared earlier in the Lower Pecos than in Central Texas, such characteristics as beveled stems and overall morphology may have originated in the Lower Pecos. Shafer's (1963:67) surprise that Nolan points, which are more common in sites to the south and west, were not found in greater numbers at the Youngsport site might support the idea that bearers of these darts came out of the Lower Pecos and moved into adjacent portions of central Texas, but did not utilize all portions of central Texas equally. At the same time, a shift to more-xeric conditions bore witness to the formation of burned rock middens, probably because intensified use of a specific resource (geophytic or xerophytic plants) or resource patches meant the debris of multiple rock ovens and hearths accumulated as middens on stable to slowly aggrading surfaces, as Kelley and Campbell (1942) suggested many years ago. Johnson and Goode (1994:26) believe that the 
dry conditions promoted the spread of yuccas and sotols, and that it was these plants that Middle Archaic peoples collected and cooked in large rock ovens.

During the succeeding Late Archaic period (4000 to 1300-1200 B.P.), populations continued to increase (Prewitt 1985:217). Within stratified Archaic sites such as Loeve-Fox, Cibolo Crossing, and Panther Springs Creek, the Late Archaic components contain the densest concentrations of cultural materials. Establishment of large cemeteries along drainages suggests certain groups had strong territorial ties (Story 1985:40). A variety of projectile point styles appeared throughout the Late Archaic period. Johnson and Goode (1994:29-35) divide the Late Archaic into two parts, Late Archaic I and II, based on increased population densities and perceived evidence of Eastern Woodland ceremonial rituals and religious ideological influences. Middle Archaic subsistence technology, including the use of rock and earth ovens, continued into the Late Archaic period. Collins (1995:384) states that, at the beginning of the Late Archaic period, the use of rock ovens and the resultant formation of burned rock middens reached its zenith and that the use of rock and earth ovens declined during the latter half of the Late Archaic. There is mounting data that midden formation culminated much later, however, and that this high level of rock and earth oven use continued into the early Late Prehistoric period (Black et al. 1997:270-284; Kleinbach et al. 1995:795). A picture of prevalent burned rock midden development in the eastern part of the Central Texas region after 2000 B.P. is becoming clear. This scenario parallels the widely recognized occurrence of post2000 B.P. middens in the western reaches of the Edwards Plateau (see Goode 1991).

The use of rock and earth ovens for processing and cooking plant foods suggests that this technology was part of a generalized foraging strategy. The amount of energy involved in collecting plants, constructing hot rock cooking appliances, and gathering fuel ranks most plant foods relatively low based on the resulting caloric return (Dering 1999). This suggests that plant foods were part of a broad-based diet (Kibler and Scott 2000:134) or part of a generalized foraging strategy, an idea Prewitt (1981) put forth earlier. At times during the Late Archaic, this generalized foraging strategy appears to have been marked by shifts to a specialized economy focused on bison hunting (Kibler and Scott 2000:125-137). Castroville, Montell, and Marcos dart points are elements of tool kits often associated with bison hunting (Collins 1968). Archeological evidence of this link is seen at Bonfire Shelter in Val Verde County (Dibble and Lorrain 1968), Jonas Terrace (Johnson 1995), Oblate Rockshelter (Johnson et al 1962:116), John Ischy (Sorrow 1969), and Panther Springs Creek (Black and McGraw 1985).

The Archaic period represents a hunting and gathering way of life that was successful and that remained virtually unchanged for more than 7,500 years. This notion is based in part on fairly consistent artifact and tool assemblages through time and place and on resource patches that were used continually for several millennia, as the formation of burned rock middens shows. This pattern of generalized foraging, though marked by brief shifts to a heavy reliance on bison, continued almost unchanged into the succeeding Late Prehistoric period.

\section{Late Prehistoric Period}

Introduction of the bow and arrow and, later, ceramics into Central Texas marked the Late Prehistoric period (1300-1200 to 300 B.P.). Population densities dropped considerably from their Late Archaic peak (Prewitt 1985:217). Subsistence strategies did not differ greatly from the preceding period, although bison again became an important economic resource during the late part of the Late Prehistoric period (Prewitt 1981:74). Use of rock and earth ovens for plant food processing and the subsequent development of burned rock middens continued throughout the Late Prehistoric period (Black et al. 1997; Kleinbach et al. 1995:795). Horticulture came into play very late in the region but was of minor importance to overall subsistence strategies (Collins 1995:385).

In Central Texas, the Late Prehistoric period generally is associated with the Austin and Toyah phases (Jelks 1962; Prewitt 1981:82-84). Austin and Toyah phase horizon markers, Scallorn-Edwards and Perdiz arrow points, respectively, are distributed across most of the state. Violence and conflict often marked introduction of Scallorn and Edwards arrow points into Central Texas-many excavated burials contain these point tips in contexts indicating 
they were the cause of death (Prewitt 1981:83). Subsistence strategies and technologies (other than arrow points) did not change much from the preceding Late Archaic period. Prewitt's (1981) use of the term "Neoarchaic" recognizes this continuity. In fact, Johnson and Goode (1994:39-40) and Collins (1995:385) state that the break between the Austin and Toyah phases could easily and appropriately represent the break between the Late Archaic and the Late Prehistoric.

Around 1000-750 B.P., slightly more-xeric or drought-prone climatic conditions returned to the region, and bison came back in large numbers (Huebner 1991; Toomey et al. 1993). Using this vast resource, Toyah peoples were equipped with Perdiz point-tipped arrows, end scrapers, four-beveled-edge knives, and plain bonetempered ceramics. Toyah technology and subsistence strategies represent a completely different tradition from the preceding Austin phase. Collins (1995:388) states that formation of burned rock middens ceased as bison hunting and group mobility obtained a level of importance not witnessed since Folsom times. Although the importance of bison hunting and high group mobility hardly can be disputed, the argument that burned rock midden development ceased during the Toyah phase is tenuous. A recent examination of Toyah-age radiocarbon assays and assemblages by Black et al. (1997) suggests that their association with burned rock middens represents more than a "thin veneer" capping Archaic-age features. Black et al. (1997) claim that burned rock midden formation, although not as prevalent as in earlier periods, played a role in the adaptive strategies of Toyah peoples.

\section{Historic Period}

Hester (1989) and Newcomb (1961) provide historical accounts of Native Americans and their interactions with the Spanish, the Republic of Mexico, the Texas Republic, and the United States throughout the region. The beginning of the late seventeenth century and the early eighteenth century was an era of more-permanent contact between Europeans and Native Americans as the Spanish moved northward out of Mexico to establish settlements and missions on their northern frontier (see Castañeda [19361958] and Bolton [1970] for extended discussions of the mission system and Indian relations in Texas and the San Antonio area). There is little available information on aboriginal groups and their ways of life except for the fragmentary data Spanish missionaries gathered. In the San Antonio area and areas to the south, these groups have been referred to collectively as Coahuiltecans because of an assumed similarity in way of life, but many individual groups may have existed (Campbell 1988). Particular Coahuiltecan groups, such as the Payaya and Juanca, have been identified as occupying the San Antonio area (Campbell 1988). This area also served as a point of contact between the southward-advancing Apaches and the Spanish, with native groups often caught in between. Disease and hostile encounters with Europeans and intruding groups such as the Apache were already wreaking their inevitable and disastrous havoc on native social structures and economic systems by this time.

Establishment of the mission system in the first half of the eighteenth century to its demise around 1800 brought the peaceful movement of some indigenous groups into mission life, but others were forced in or moved in to escape the increasing hostilities of southward-moving Apaches and Comanches. Many of the Payaya and Juanca lived at Mission San Antonio de Valero (the Alamo), but so many died there that their numbers declined rapidly (Campbell 1988:106, 121-123). By the end of the mission period, European expansion and disease and intrusions by other Native American peoples had decimated many Native American groups. The small numbers of surviving Payaya and Juanca were acculturated into mission life. The last references to the Juanca and Payaya were recorded in 1754 and 1789 , respectively, in the waning days of the mission (Campbell 1988:98, 123). By that time, intrusive groups such as the Tonkawa, Apache, and Comanche had moved into the region to fill the void. Outside of the missions, few sites attributable to these groups have been investigated. To complicate matters, many aboriginal ways of life endured even after contact with the Spanish. For example, manufacture of stone tools continued even for many groups settling in the missions (Fox 1979). The nineteenth century brought the final decimation of the Native American groups and the U.S. defeat of the Apaches and Comanches and their removal to reservations. 


\section{SUMMARY OF IMPACT EVALUATIONS AND SURVEYS}

\section{3}

Thirty-three work authorizations were completed (Figure 3). These consisted of 53 Impact Evaluations, 33 Surveys, and 2 Surveys with Geoarcheological Evaluation. Combined, these work authorizations entailed efforts at 47 bridge replacements, 4 bridge rehabilitation projects, 2 locations where new bridges will be built, 20 road rehabilitation or widening projects (many also involving bridge replacements or upgrades), 1 interstate highway rest area replacement, 3 drainage improvement projects, 2 curve realignment projects, 3 projects involving construction of new roads, 1 project involving construction of a railroad grade separation, 1 pedestrian bridge construction project, 1 project involving construction of a water taxi landing, 1 project involving construction of a hike-and-bike trail, 1 project involving modification of a highway interchange, and 1 project involving documentation of an archeological site disturbed by placement of a buried utility line. During completion of these work authorizations, 26 newly discovered or previously recorded archeological sites were investigated. This section begins with an outline of the methods used in accomplishing the work authorizations. Next, the work efforts are summarized in terms of distribution and setting, followed by a discussion of the existing disturbances observed as they relate to the potential for archeological remains in good context at these locations and descriptions of the sites investigated. The section closes with a discussion of the utility of the fieldwork done under these work authorizations.

\section{METHODS}

Each work authorization done under this contract began with acquisition and review of the appropriate USGS map(s), review of geologic and soil maps, a file search at the Texas Archeological Research Laboratory or the online Texas Archeological Sites Atlas for known sites in and near the project area, and review of project plans to identify impact areas. The field methods employed varied depending on the type of project.

For Impact Evaluations, fieldwork typically consisted of on-the-ground examination of existing and proposed right of way on both sides of the road along the full length of the project area. Where right of entry had not been obtained for known or potential impact areas beyond the existing right of way, these areas were inspected visually across fence lines. The ground surface and any disturbed areas (e.g., road cuts, the backdirt of recently placed fiber optic or telephone lines, plowed fields, and so on) within and adjoining the existing right of way were examined for evidence of archeological remains. The primary thrust, however, was to record the kinds and extent of disturbance and determine the likelihood of archeological remains in undisturbed contexts. In most cases, this entailed examining visible stream cutbanks and overall landscape geometry to form an opinion about the thickness and extent of Holocene alluvium that could host buried archeological deposits. Shovel tests were not dug because cutbanks and landscape geometry provided adequate information on sediment thickness.

For each bridge replacement or other Transportation Activity, a standardized Impact Evaluation form was completed recording anticipated impacts, location and extent of disturbances (e.g., ditches, fill sections, underground utilities, gullying and erosion, and other), location and extent of undisturbed right of way; surface visibility; subsurface exposures; 


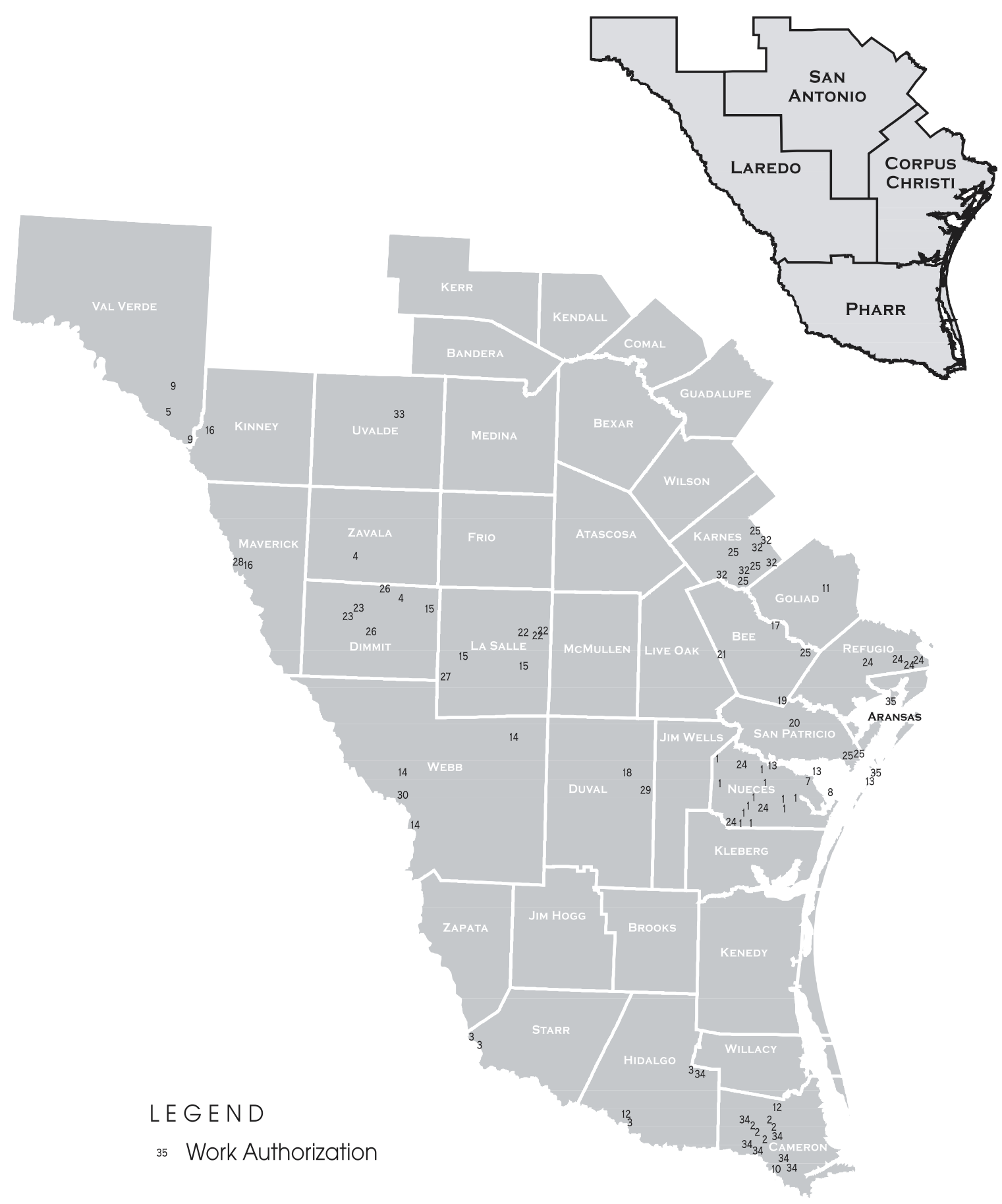

PAI/O5/SLH

Figure 3. Map of the study area showing the locations of all Impact Evaluations and Surveys. 
geologic-geomorphic setting; nature, thickness, and origin of sediments; archeological remains observed; recommendations; land use; vegetation; personnel; and time spent. Each project area also was documented with color photographs. One or two people did Impact Evaluations, with the typical bridge replacement requiring 1-2 hours. Each of the Impact Evaluations that involved long stretches of highway was carried out as a series of on-the-ground inspections (i.e., at each stream crossing) following the methods outlined above, with the intervening upland areas generally subjected to windshield inspection.

For Surveys and Surveys with Geoarcheological Evaluations, fieldwork included excavating enough backhoe or Gradall trenches, or shovel tests to constitute a good-faith effort toward determining whether archeological sites are present. As listed in Table 1, 96 trenches were excavated in 14 of the 35 survey areas, ranging from as few as 3 trenches to as many as 19. On 6 surveys, a total of 40 shovel tests were dug in addition to trenches (range $=4-12$ tests). On 2 surveys (both done under Work Authorization 9), 11 test pits measuring $0.5 \times 0.5 \mathrm{~m}$ were dug in addition to trenches. On 21 surveys, only shovel tests $(n=266)$ were dug. Twenty-four of the surveys were restricted to existing rights of way; substantial parts of these survey areas (often half or more) were disturbed by existing roads and bridges. These 24 surveys involved excavating 60 trenches and 156 shovel tests. Eleven survey areas had relatively undisturbed new right of way or easements varying from 0.25 to 394 acres in size (median $=13.1$; total $=$ 669.85 acres [acreage figures exclude 1 survey where the amount of new right of way was unknown at the time of survey]). Thirty-six trenches and 150 shovel tests were excavated in surveying these areas. Trenches and shovel tests usually were placed according to the size and shape of each survey area, distributions of landforms, accessibility, and the locations of known sites rather than at specific intervals.

The trenches were at least $5 \mathrm{~m}$ long and $0.75 \mathrm{~m}$ wide and were usually at least $1.5 \mathrm{~m}$ deep (i.e., the anticipated maximum depth of substantial disturbance). After excavation, their walls were cleaned and examined for cultural materials. Stratigraphic descriptions were prepared for selected trenches to characterize the sediments. Shovel tests averaged $30 \mathrm{~cm}$ in diameter and were dug to varying depths depending on depth to bedrock, clay content, and water content. The sediments removed from shovel tests were screened through 1/4-inch-mesh hardware cloth. A standardized Survey Summary Form was completed noting whether the survey included a geoarcheological evaluation; describing the areas subjected to surface survey; noting visibility; indicating the number, depth, and placement of shovel tests and trenches; listing the cultural materials observed and sites recorded; providing assessments and recommendations; and noting the personnel and time needed for the survey. Other documentation consisted of color photographs, Temporary Site Forms (for eventual submittal to the Texas Archeological Research Laboratory in TexSite format), stratigraphic profile descriptions, and project plans showing the locations of all trenches, shovel tests, and sites. Surveys usually were done by two-person crews; on Surveys with Geoarcheological Evaluations, one member of the crew was a geoarcheologist. The time required to complete the surveys varied depending on their size, the number of trenches and shovel tests excavated, and what was found. The range was $2.5-48$ person-hours, with the median being 16 person-hours (excludes time spent by TxDOT personnel, including backhoe and Gradall operators).

\section{SYNOPSIS OF WORK AUTHORIZATIONS}

As listed in Table 1, 43 of the 88 projects were in the Corpus Christi District (Aransas, Bee, Goliad, Karnes, Live Oak, Nueces, Refugio, and San Patricio Counties), 25 were in the Laredo District (Dimmit, Duval, Kinney, La Salle, Maverick, Val Verde, Webb, and Zavala Counties), 19 were in the Pharr District (Cameron, Hidalgo, and Starr Counties), and 1 was in the San Antonio District (Uvalde County).

The projects in the Corpus Christi District consisted of 29 Impact Evaluations and 14 Surveys for replacing 30 bridges, rehabilitating 1 existing bridge, rehabilitating or widening 6 roads, realigning a curve on 1 road, constructing 3 new roads, constructing 1 water taxi landing, and modifying a highway interchange. In the Laredo District, the work authorizations were for 7 Impact Evaluations, 16 Surveys, and 
Archeological Impact Evaluations and Surveys

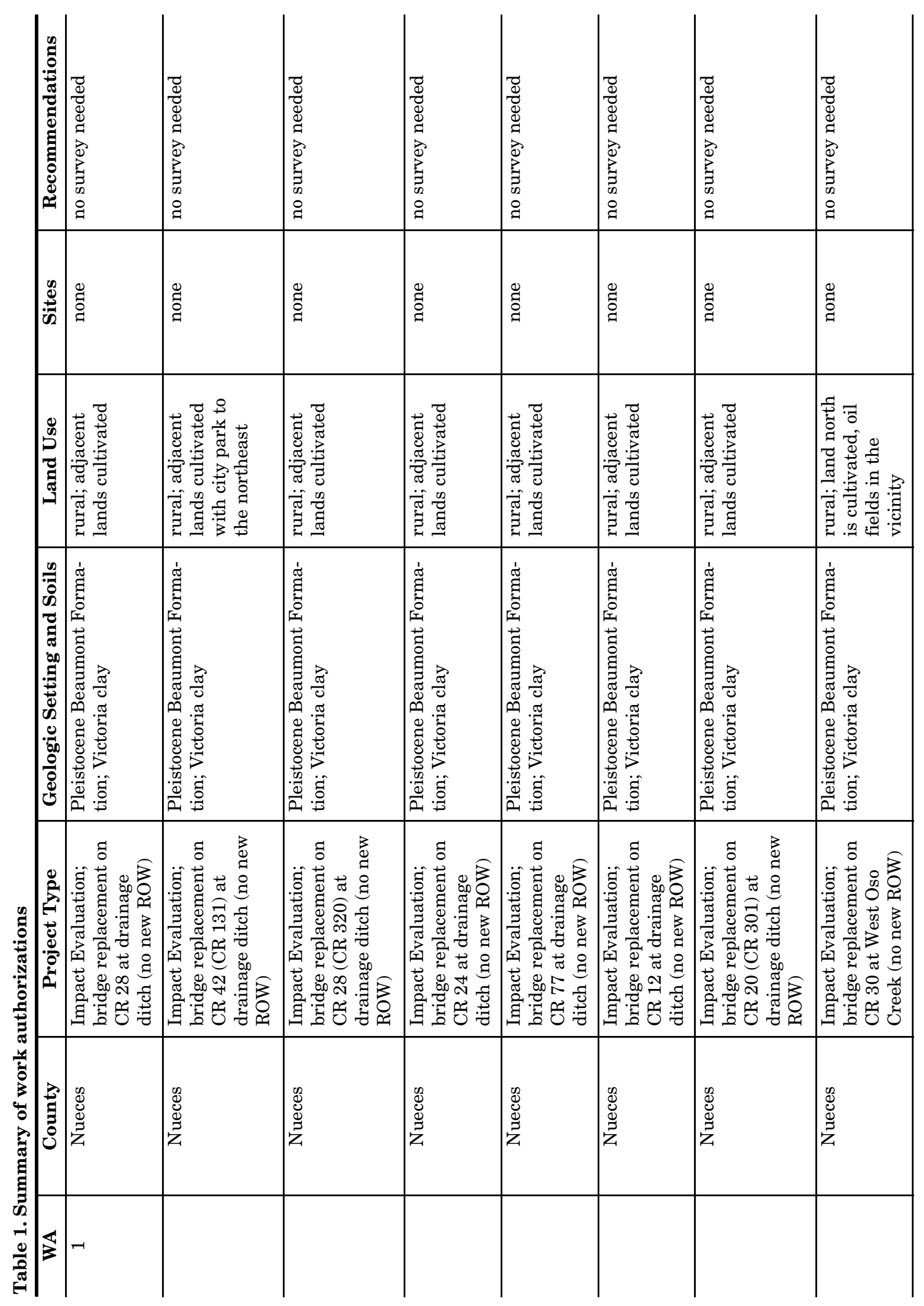


Chapter 3: Summary

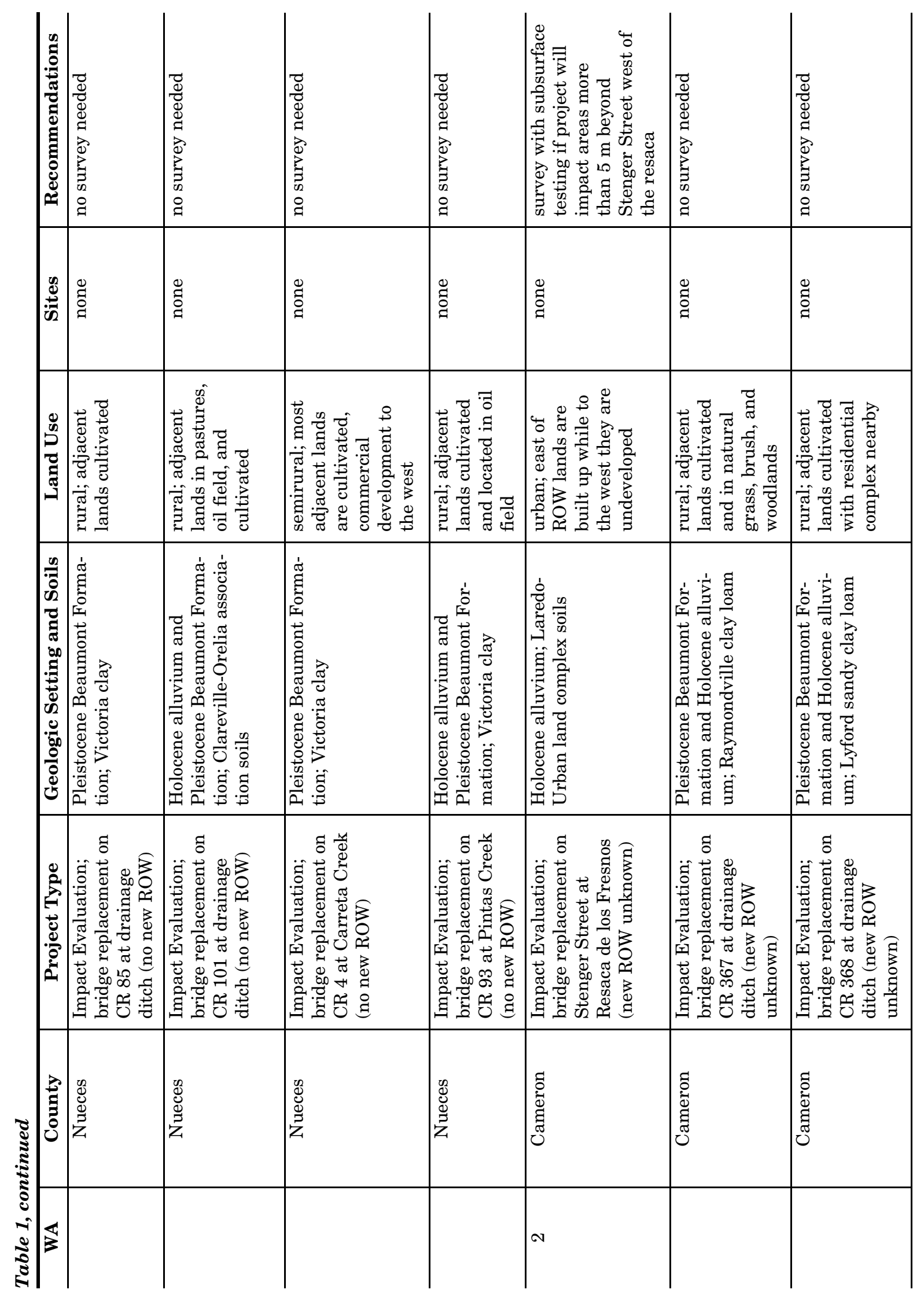




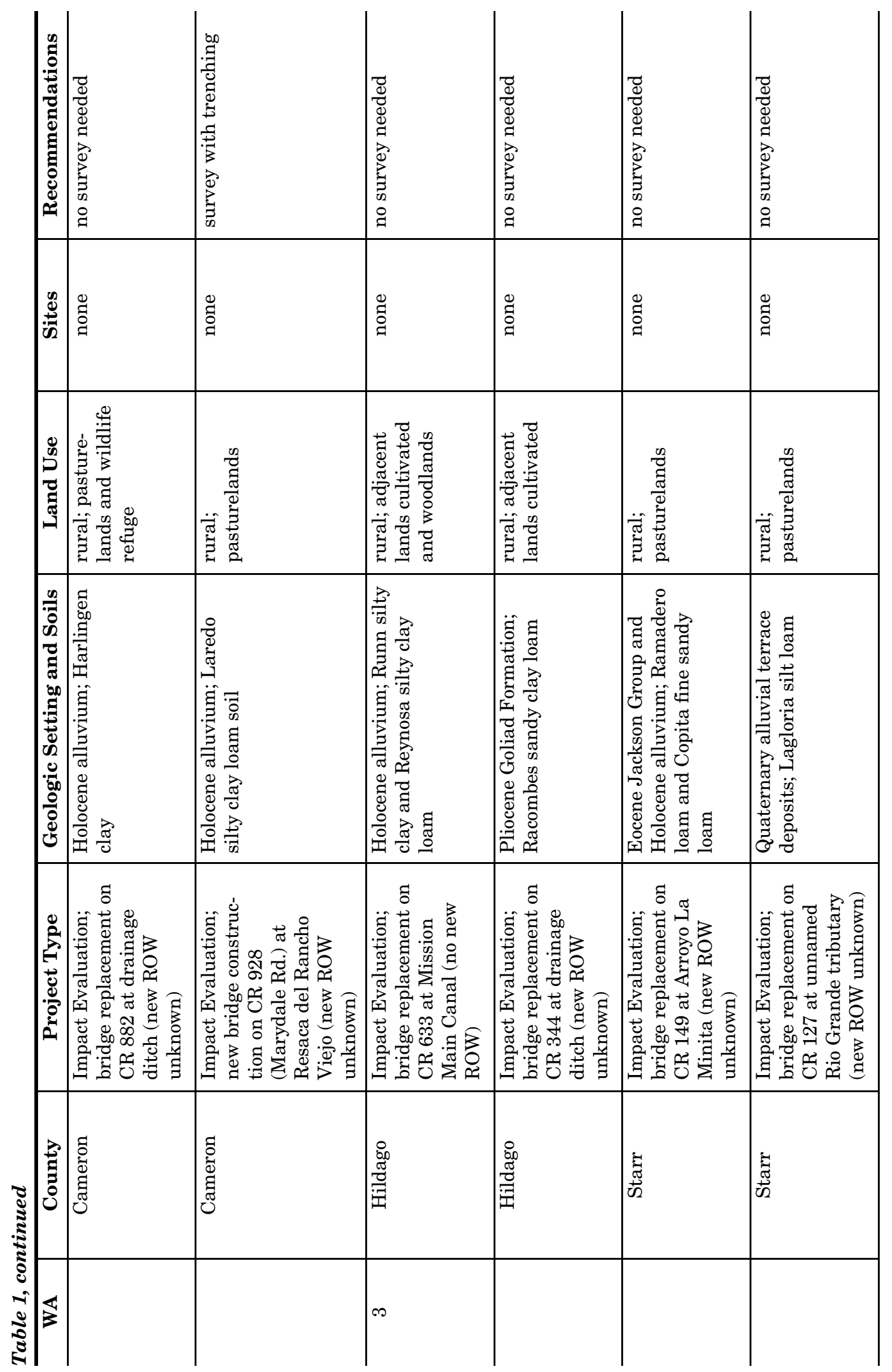


Chapter 3: Summary

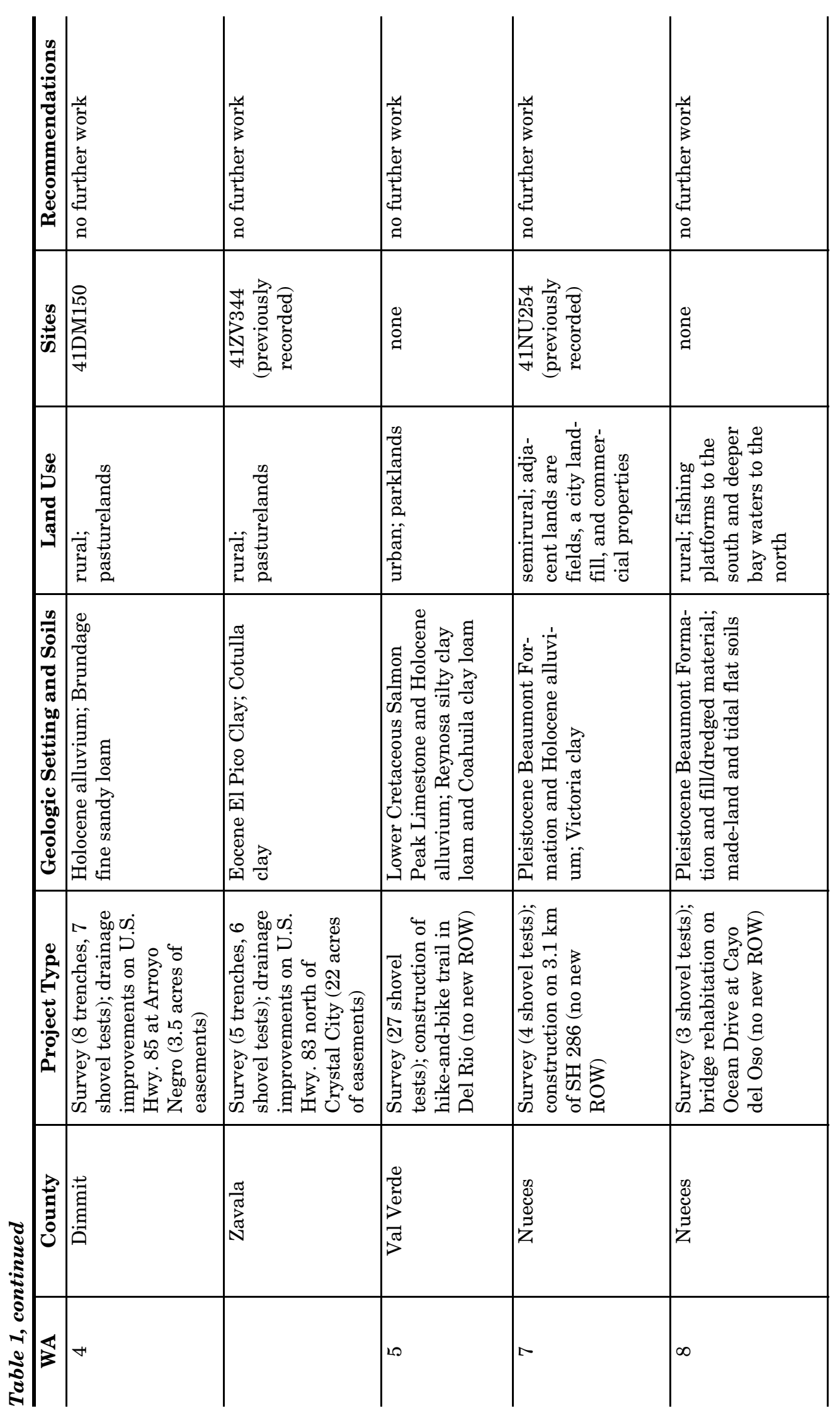


Archeological Impact Evaluations and Surveys

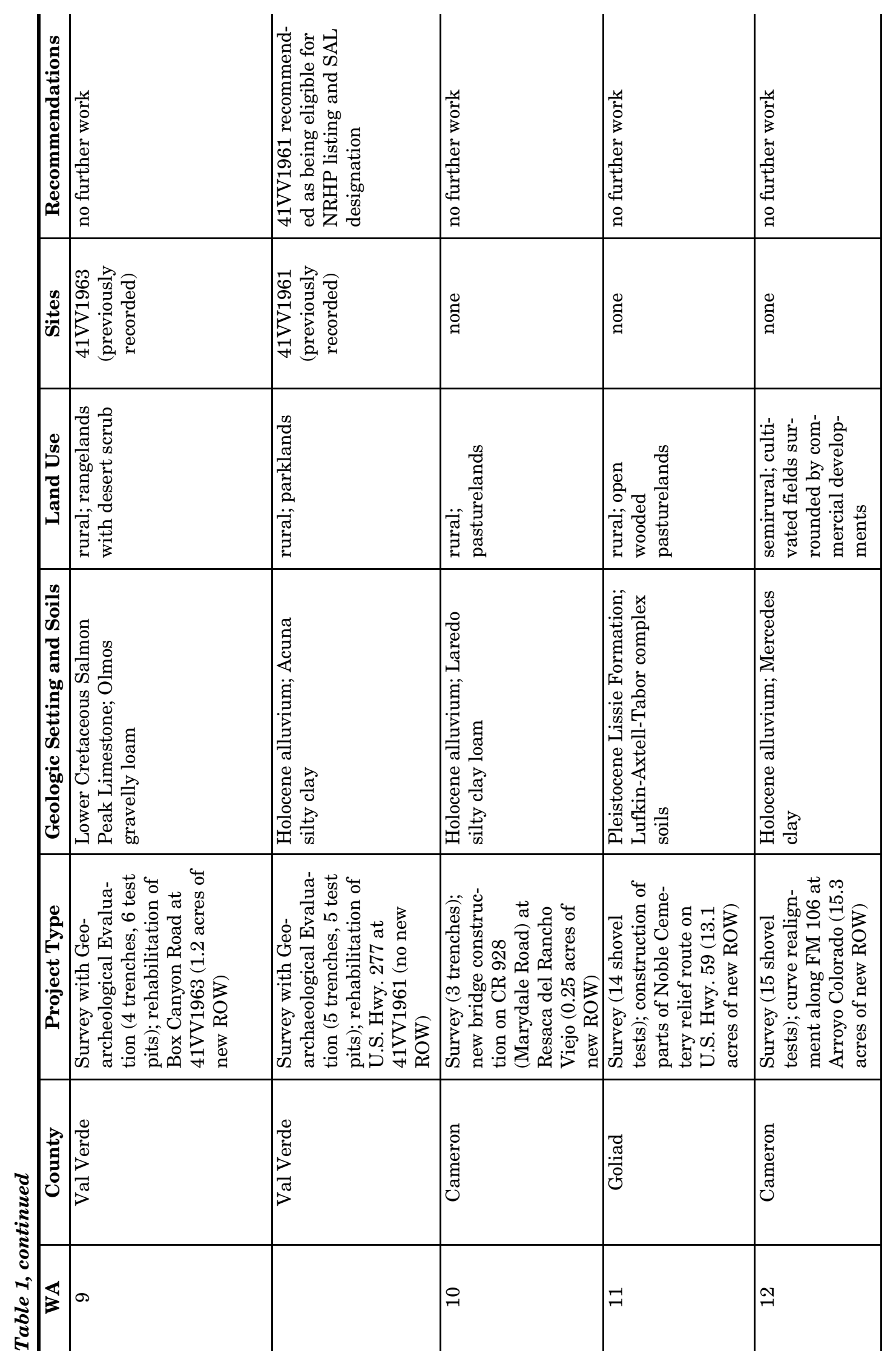


Chapter 3: Summary

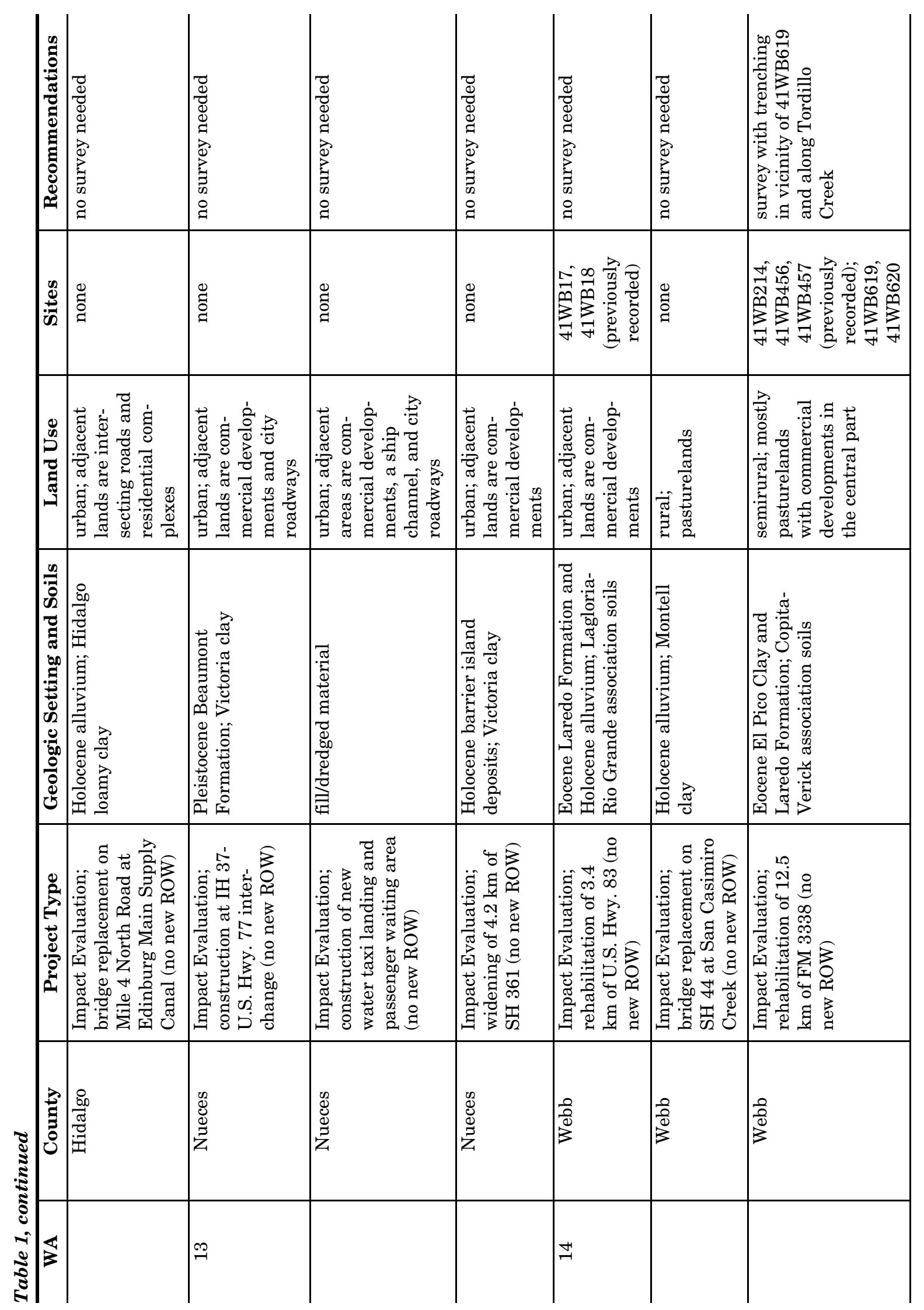




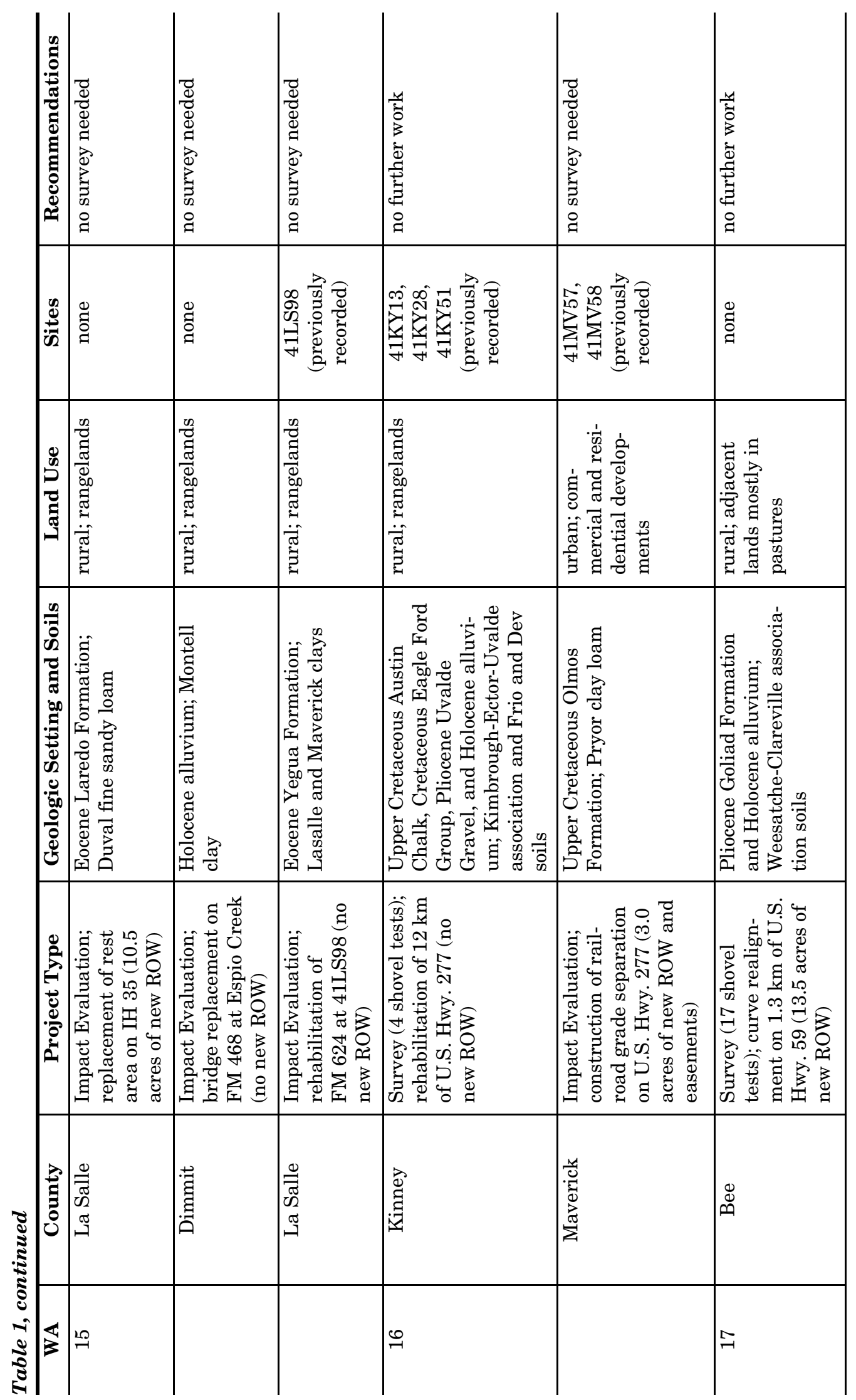


Chapter 3: Summary

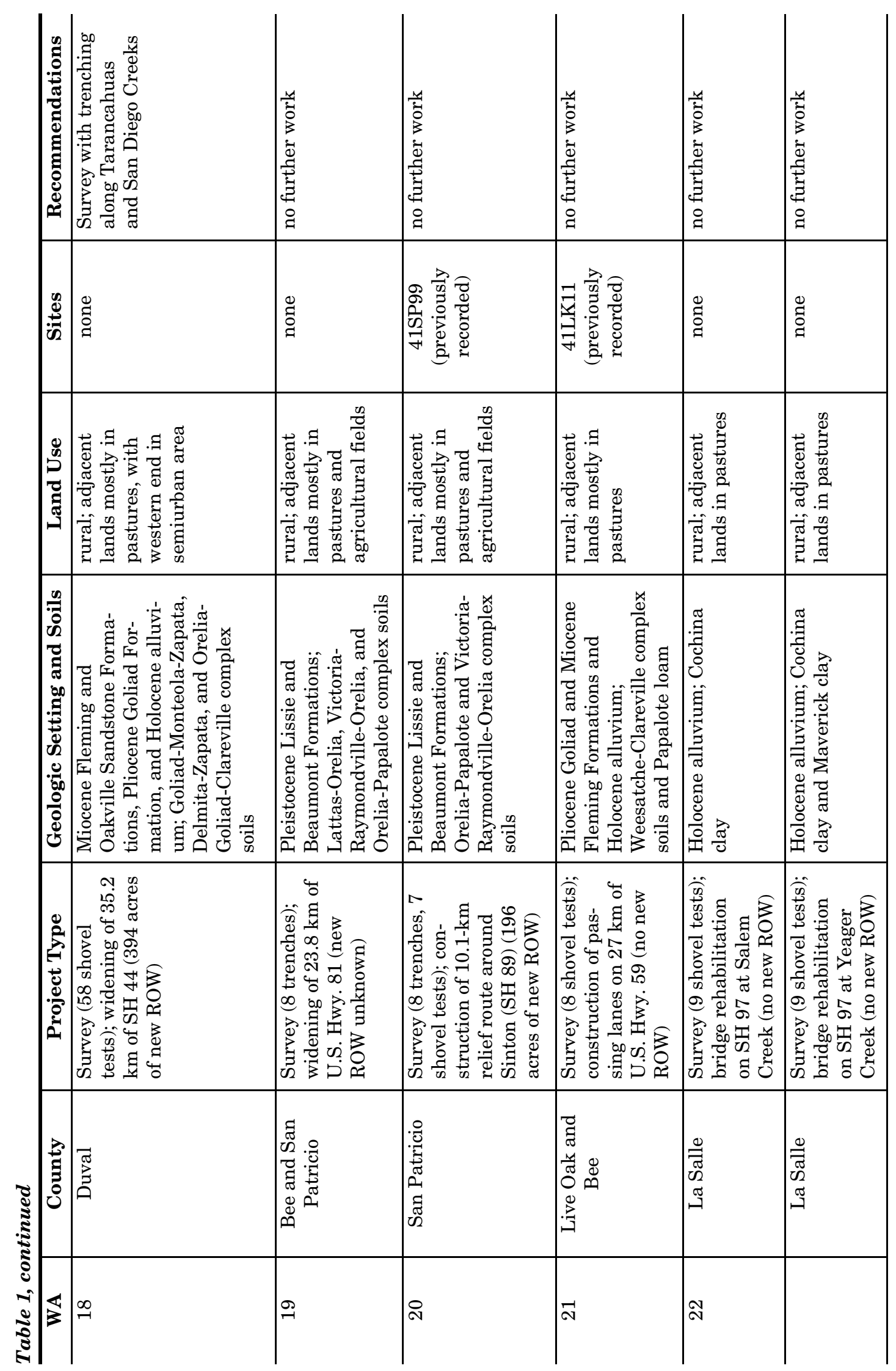




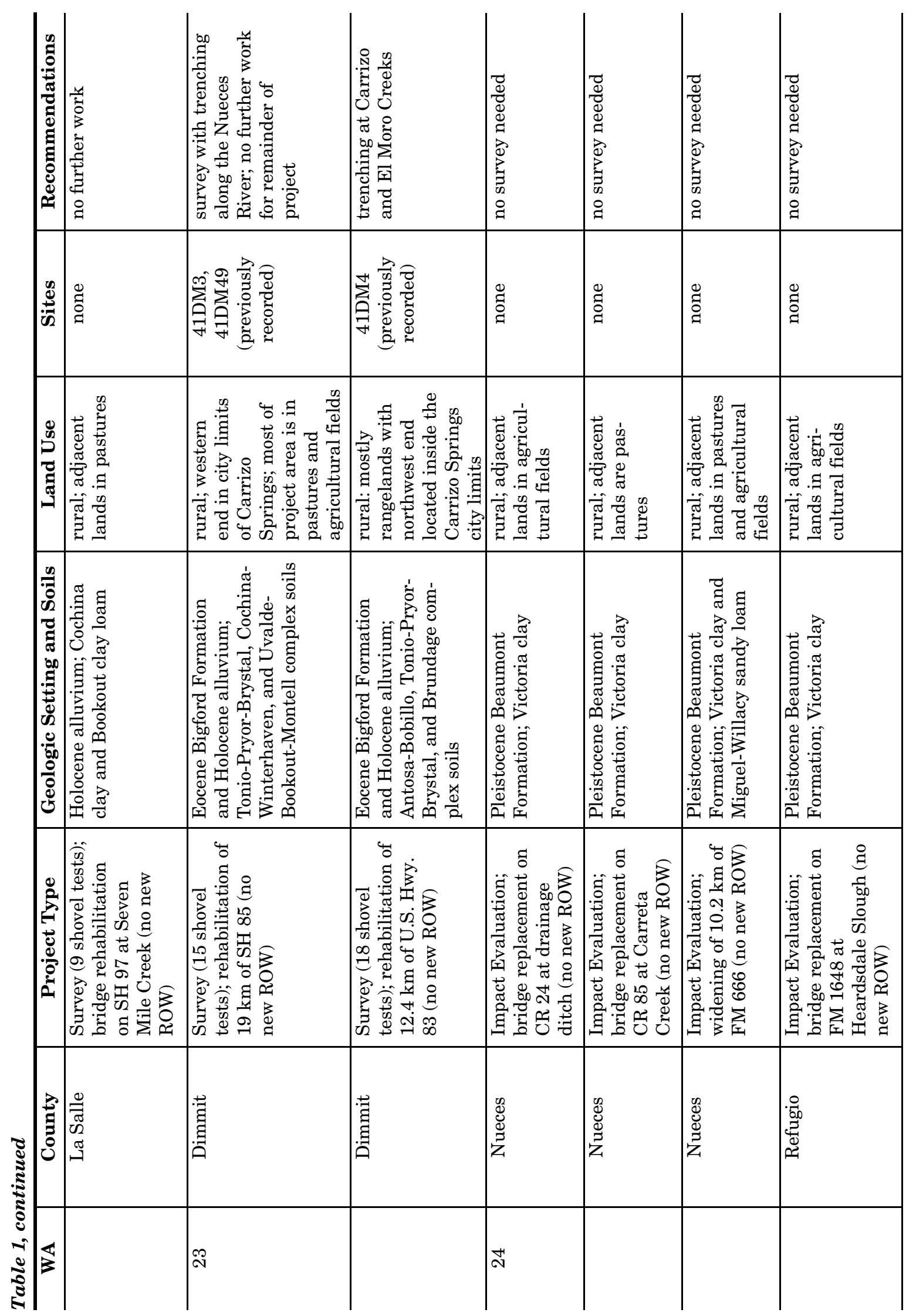


Chapter 3: Summary

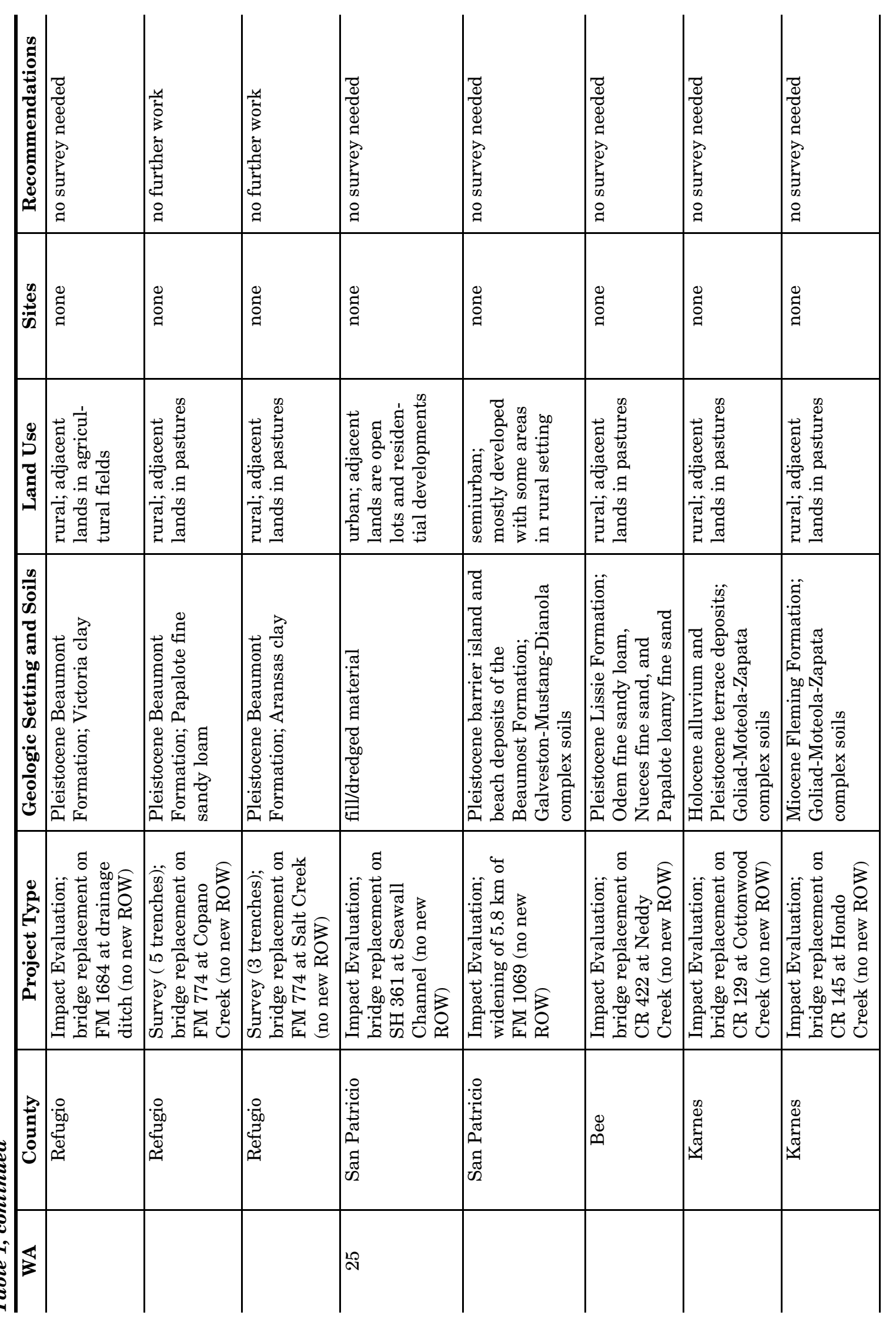




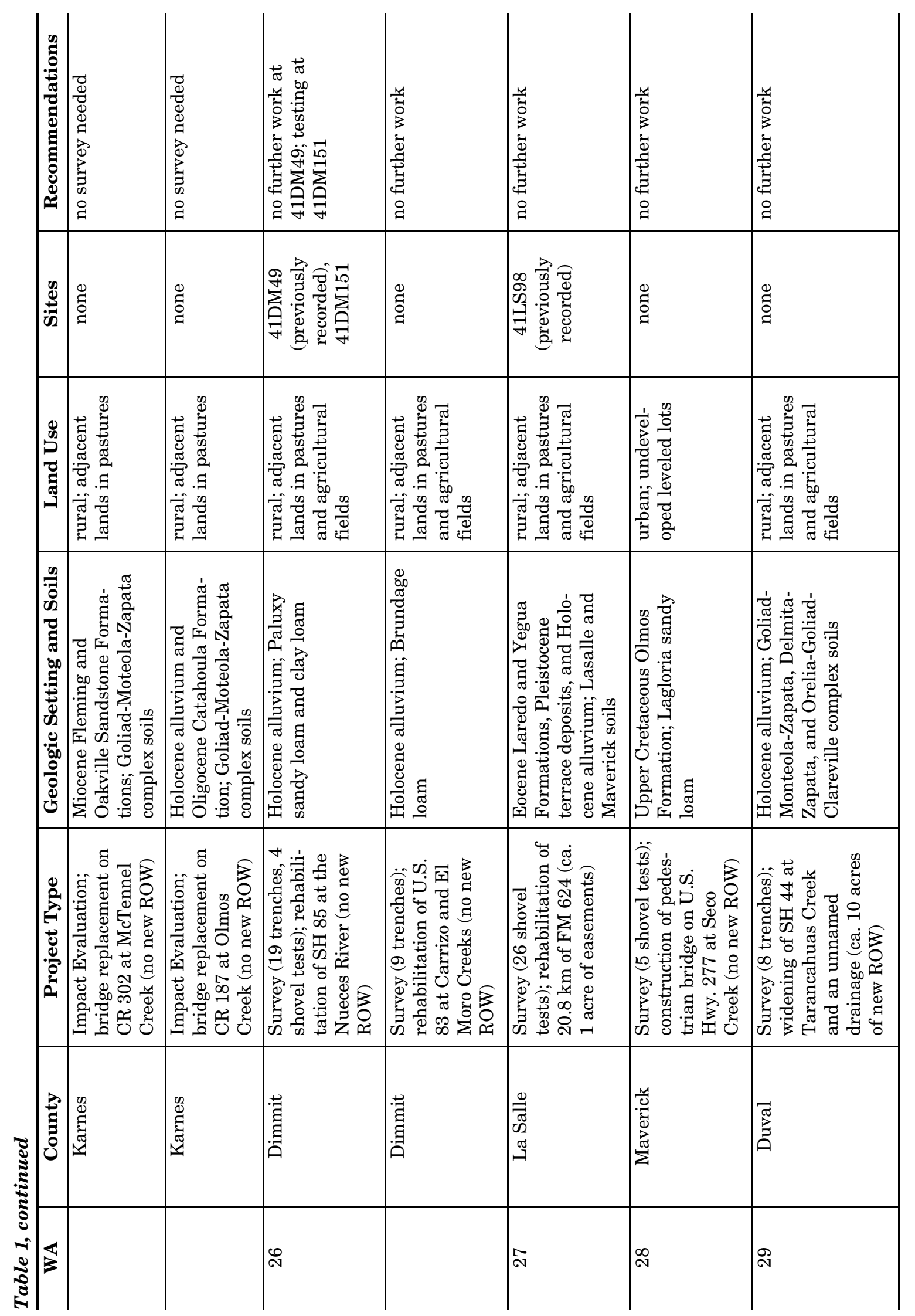


Chapter 3: Summary

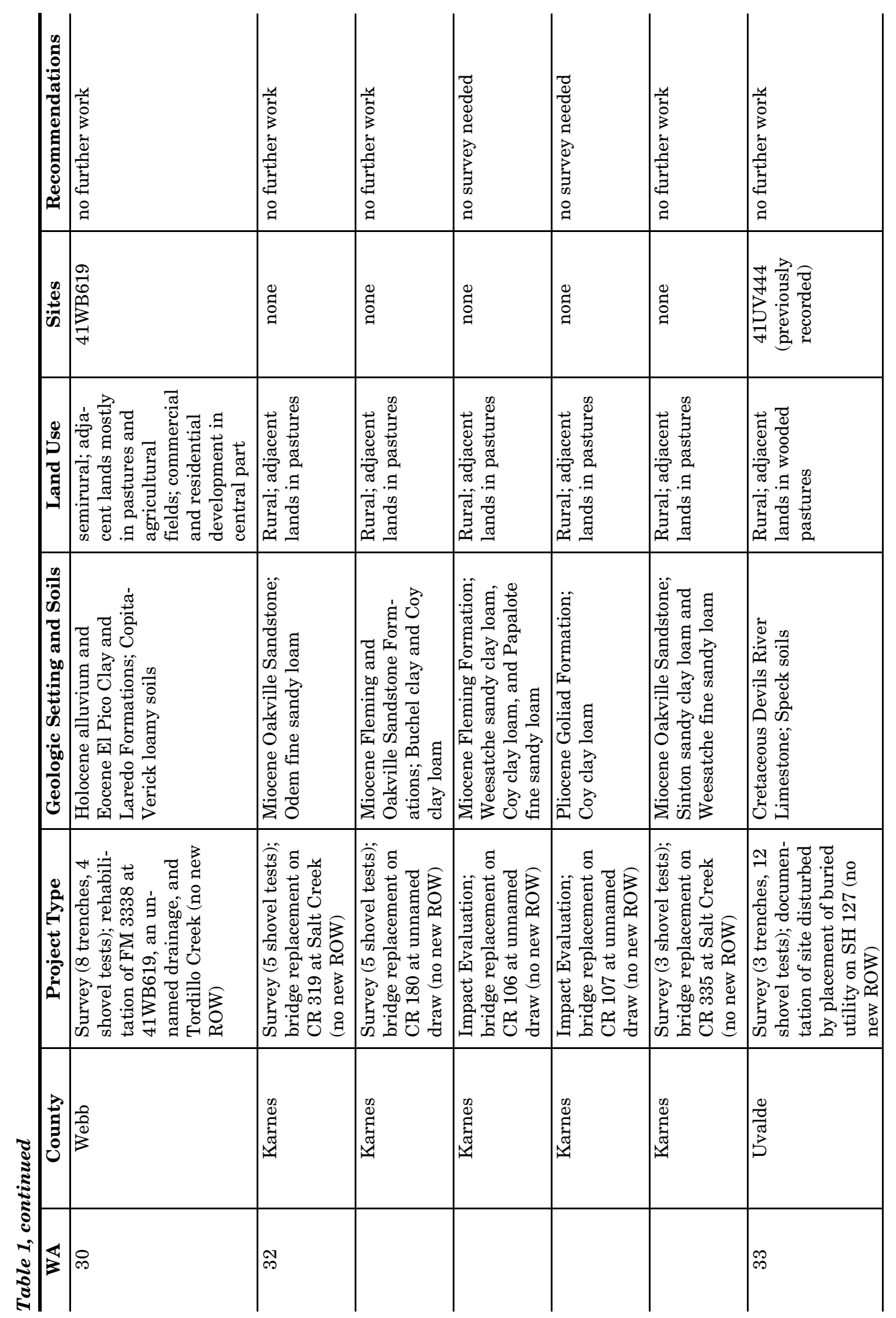


Archeological Impact Evaluations and Surveys

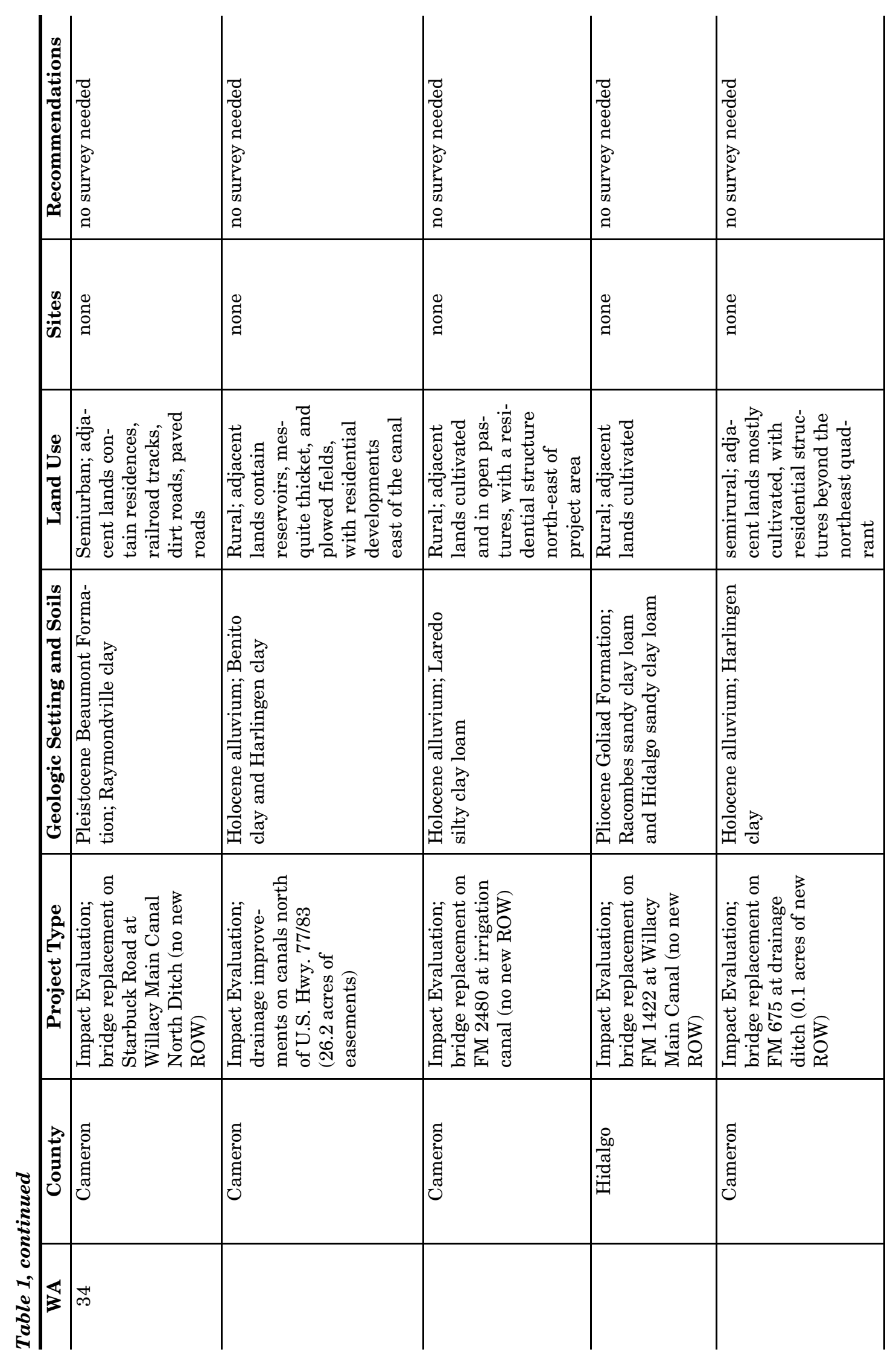


Chapter 3: Summary

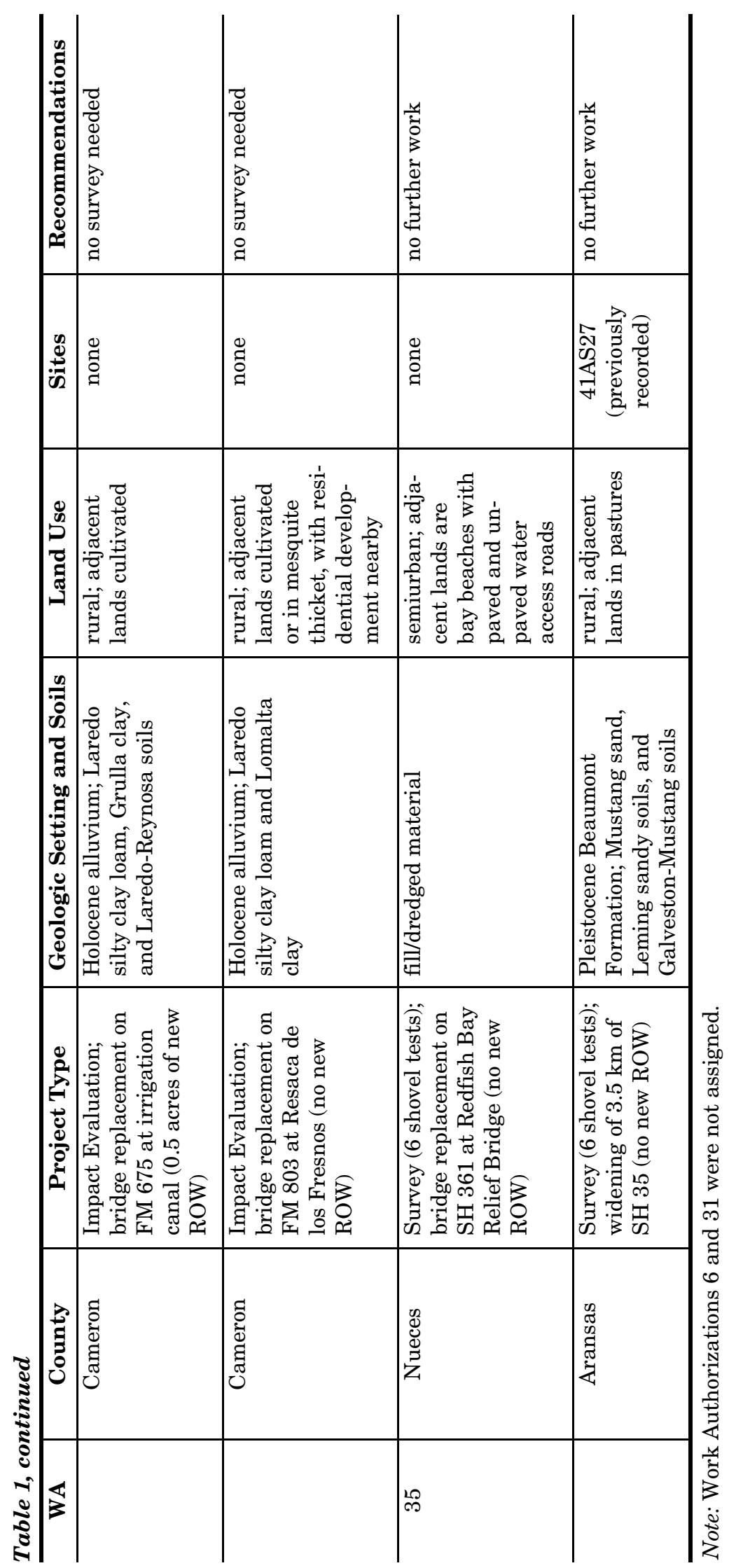


2 Surveys with Geoarcheological Evaluation for replacing 2 bridges and rehabilitating 3 others, rehabilitating or widening 14 roads, replacing 1 interstate highway rest area, improving drainages along 2 roads, constructing a railroad grade separation on 1 road, constructing a pedestrian bridge on 1 road, and constructing 1 hike-andbike trail. The projects in the Pharr District consisted of 17 Impact Evaluations and 2 Surveys for 15 bridge replacements, construction of 2 new bridges, 1 drainage improvement project, and 1 curve realignment project. The lone project in the San Antonio District consisted of a Survey to document a prehistoric site disturbed by placement of a buried utility line.

Twenty-three of the projects, most involving bridge replacements, were restricted to settings mapped as Holocene alluvium or barrier island deposits (see Table 1). Another 18 Impact Evaluations and Surveys encompassed uplands as well as Holocene alluvial settings, with the uplands mapped as a variety of Pleistocene (Beaumont, Lissie, and fluviatile terrace), Pliocene (Goliad and Uvalde Gravel), Miocene (Fleming and Oakville Sandstone), Oligocene (Catahoula), Eocene (Bigford, El Pico Clay, Jackson Group, Laredo, and Yegua), and Cretaceous (Austin Chalk, Eagle Ford Group, and Salmon Peak Limestone) deposits. The 44 projects that were restricted to uplands crossed the Pleistocene Beaumont and Lissie Formations and fluviatile terrace deposits; the Pliocene Goliad Formation; the Miocene Fleming and Oakville Sandstone Formations; the Eocene El Pico Clay, Laredo, and Yegua Formations; and the Cretaceous Devils River Limestone, Olmos, and Salmon Peak Limestone Formations. Three projects were in areas mapped as consisting of introduced fill or dredged materials.

A variety of soils are mapped for the project areas. Soils developed in Holocene deposits include Acuna, Aransas, Benito, Brundage, Buchel, Coahuila, Cochina, Dev, Frio, Grulla, Harlingen, Lagloria, Lomalta, Laredo, Leming, Montell, Mustang, Odem, Olmos, Paluxy, Ramadero, Reynosa, Rio Grande, Runn, Sinton, Uvalde, and Winterhaven (see Table 1). Upland and old terrace soils in these areas include Antosa, Axtell, Bobillo, Bookout, Brystal, Clareville, Copita, Cotulla, Coy, Duval, Ector, Goliad, Hidalgo, Kimbrough, Lasalle, Lattas, Lufkin, Lyford, Maverick, Mercedes, Miguel, Monteola,
Nueces, Orelia, Papalote, Pryor, Racombes, Raymondville, Speck, Tabor, Tonio, Verick, Victoria, Weesatche, Willacy, and Zapata.

Most of the Impact Evaluations and Surveys ( $\mathrm{n}=69$ ) were in rural or mostly rural areas where adjoining lands were undeveloped and usually in pastures or agricultural fields (see Table 1). Six projects were in settings that can be classified as semirural (i.e., largely undeveloped but near low-density residential or commercial areas), and three were in semiurban settings (i.e., denser residential or commercial development). Ten project areas were in urban settings (the communities of Aransas Pass, Calallen, Corpus Christi, Del Rio, Eagle Pass, Edinburg, Laredo, Port Aransas, and San Benito).

\section{IMPACTS AND SITE POTENTIAL}

A primary thrust of the Surveys and especially the Impact Evaluations performed under this contract was documentation of existing disturbances that would affect the potential of each project area to contain archeological sites with sufficient integrity to be eligible for listing in the National Register of Historic Places or designation as State Archeological Landmarks. In general, four kinds of disturbances were observed most consistently within existing rights of way: fill sections, ditches, gullies, and buried utilities (Figure 4).

Fill sections to elevate the approaches to bridges above the adjoining floodplains were present at 68 , or 77 percent, of the areas where surveys or impact evaluations were done (Table 2). These fill sections ranged from $0.2 \mathrm{~m}$ in thickness to as much as $15 \mathrm{~m}$, although most were 0.5-2.0 $\mathrm{m}$ thick. Horizontally, they extended as little as a few meters from each end of a bridge to as much as several hundred meters, depending on the size of the valley and the kind of road. The higher and longer fill sections tended to be associated with the larger roads and larger streams. Typically, fill sections extended at least several meters beyond the edges of the pavement, in some cases occupying almost all of the existing right of way. It is difficult to quantify how much disturbance is associated with the placement of fill sections, but it is assumed that at least the upper $0.5 \mathrm{~m}$ of sediment beneath and beside fill sections is disturbed by heavy machinery during construction and later by com- 


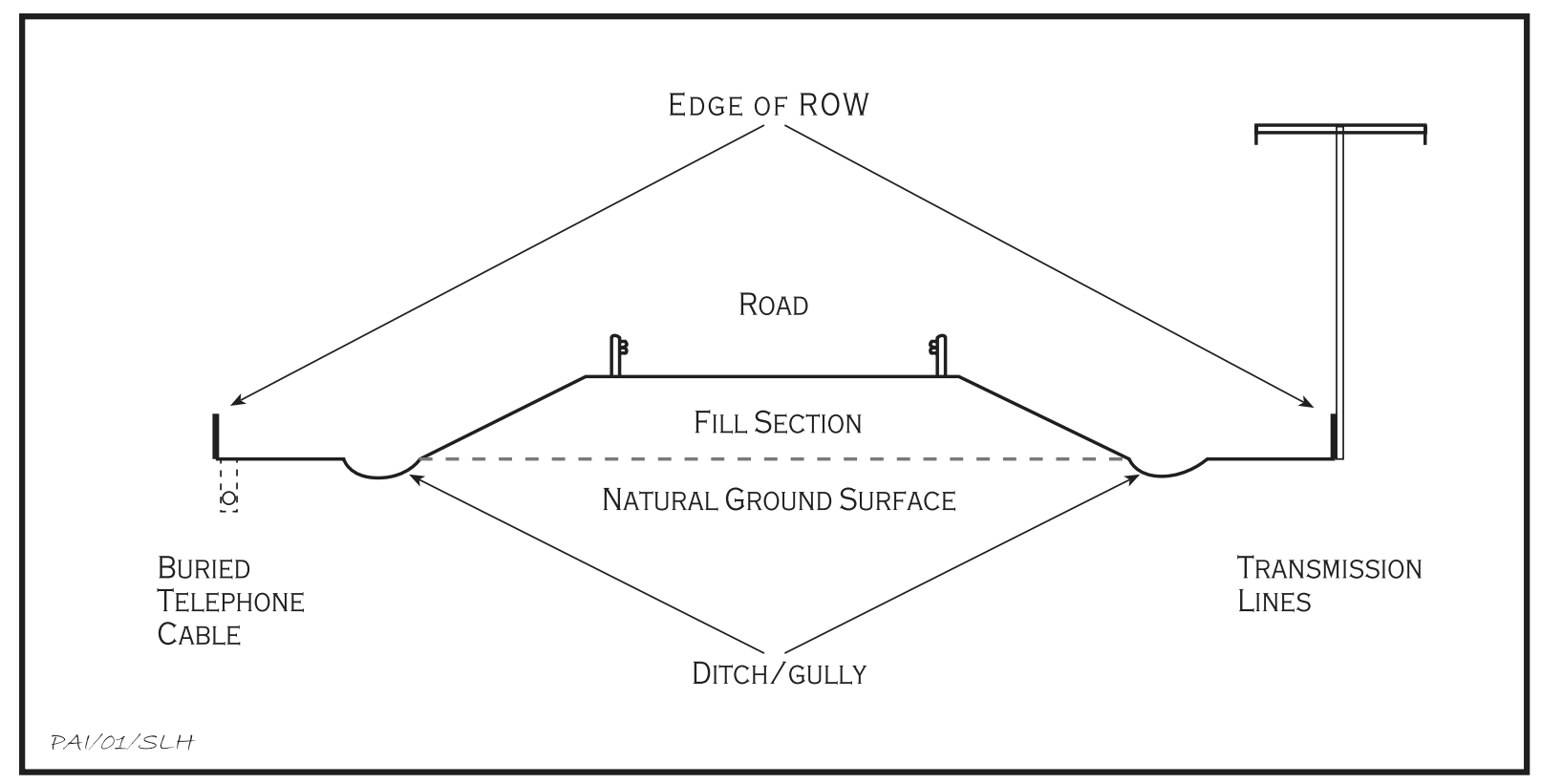

Figure 4. Schematic cross section of a bridge approach showing common disturbances.

paction. Presumably, the larger the fill section, the deeper the disturbance.

In most cases, fill sections were bordered on both sides by shallow drainage ditches (see Table 2 ). These were found at 65 percent of the project areas. They usually were less than $1 \mathrm{~m}$ deep, and often less than $0.5 \mathrm{~m}$, and they were up to several meters wide. Vegetation covered most of them, and thus they did not offer any subsurface visibility but some that had been maintained recently exposed subsurface deposits. In some of the more-developed areas, the ditches were lined with concrete. Better exposures sometimes were provided by gully erosion, which occurred in 27 percent of the project areas. Gullying was observed in the bottoms of ditches running along the edges of fill sections and breaching the creek banks. In some cases, such gullies were present at one or more corners of a bridge, often extending to depths of $0.5-1.0 \mathrm{~m}$ (see Table 2).

The fourth kind of disturbance observed consistently was underground utilities. These were present in many project areas, with the most common kind being buried telephone or fiber optic lines (see Table 2). These almost always were at one or both edges of the existing right of way and were marked by signs or areas of recent disturbance from placement of the lines. Based on the extent of the recent disturbance, it appears that trenching for these lines usu- ally had disrupted an area $0.5 \mathrm{~m}$ or less in width. Presumably, they vary in depth, with most probably being no deeper than $1 \mathrm{~m}$. More-extensive disturbance probably is associated with other kinds of underground utilities, including water lines, sewer lines, gas lines, and petroleum pipelines. These were not as ubiquitous as telephone and fiber optic lines, although some (especially water lines) may not be marked with signs as consistently as telephone and fiber optic lines. Buried utility lines were observed at 58 percent of the project areas.

A variety of other disturbances were noted less frequently (see Table 2). These included the following: old road beds; grading for road construction; culverts; construction of recreational facilities; adjacent railroad beds; two-track roads; road cuts; flood containment basins; construction of driveways and other access roads; adjacent commercial development; timber retaining walls; adjacent residential development; extensive sheet erosion; piled concrete rubble; piled dredged material; excavation of drainage ditches and canals; cattle trampling; stock ponds; and fill placement. Thirty-five percent of the project areas had one or more of these kinds of disturbances. Overhead transmission and telephone lines, which were observed along the edges of the right of way at many locations, occurred more frequently but caused little disturbance. 


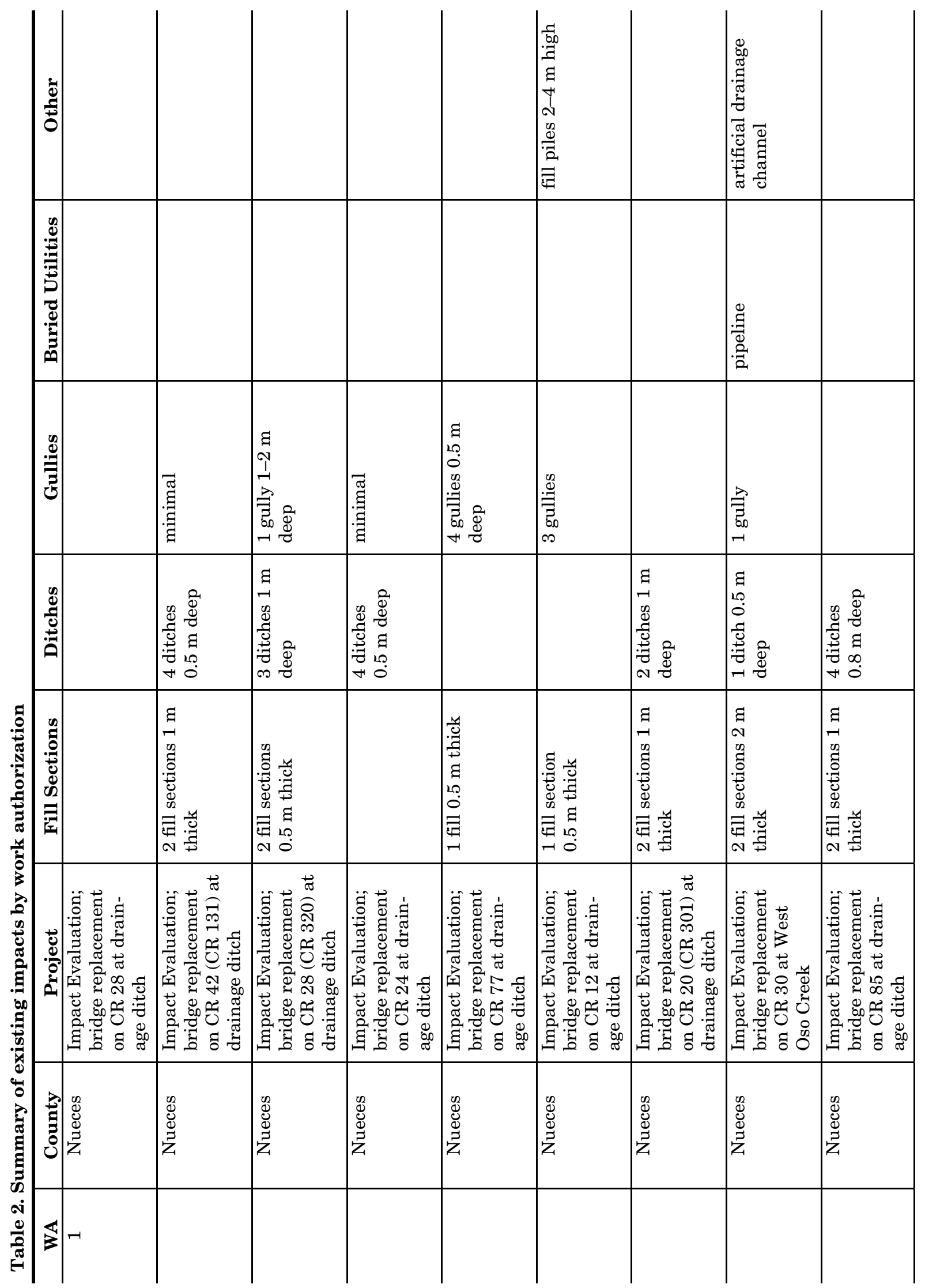




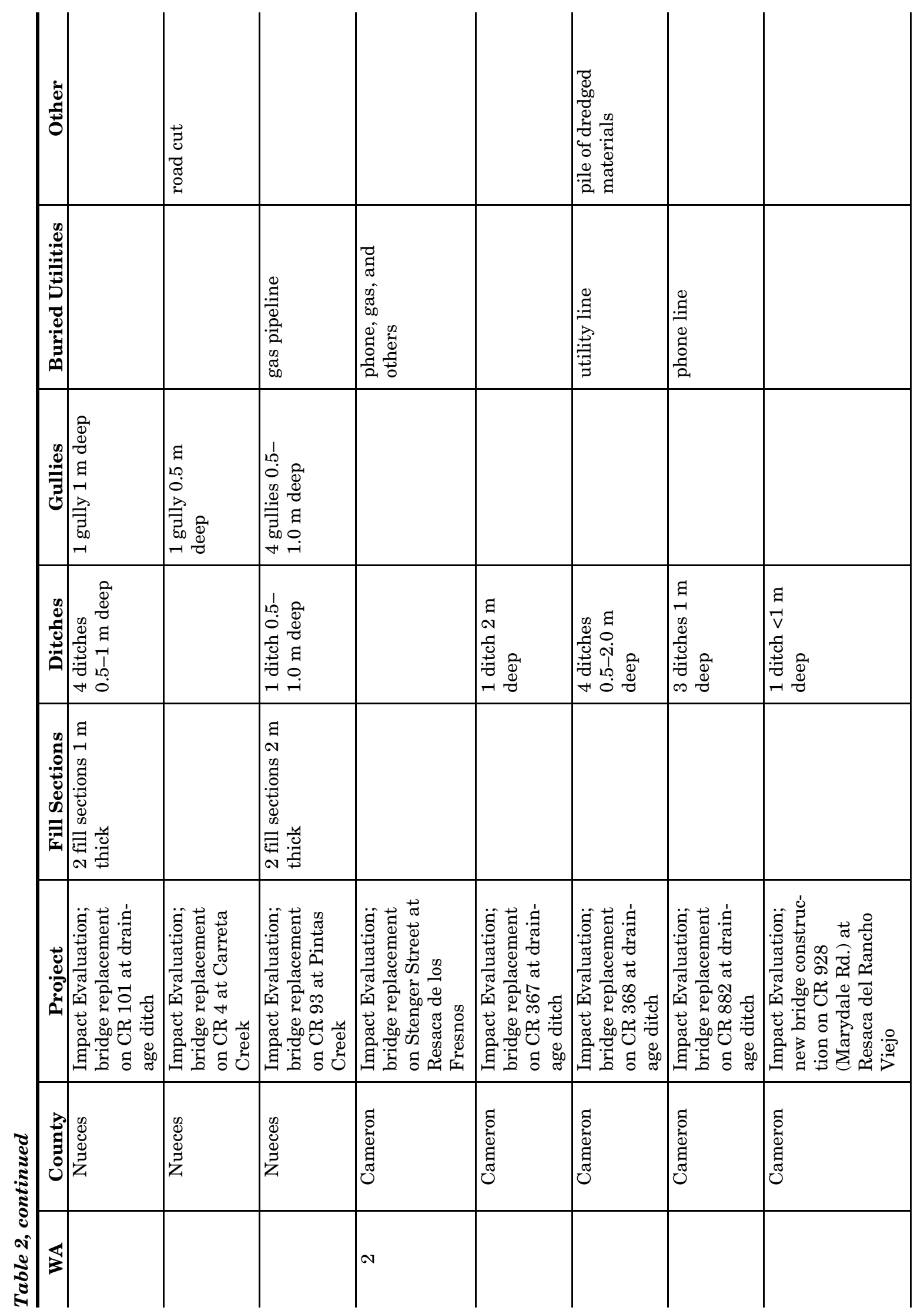


Archeological Impact Evaluations and Surveys

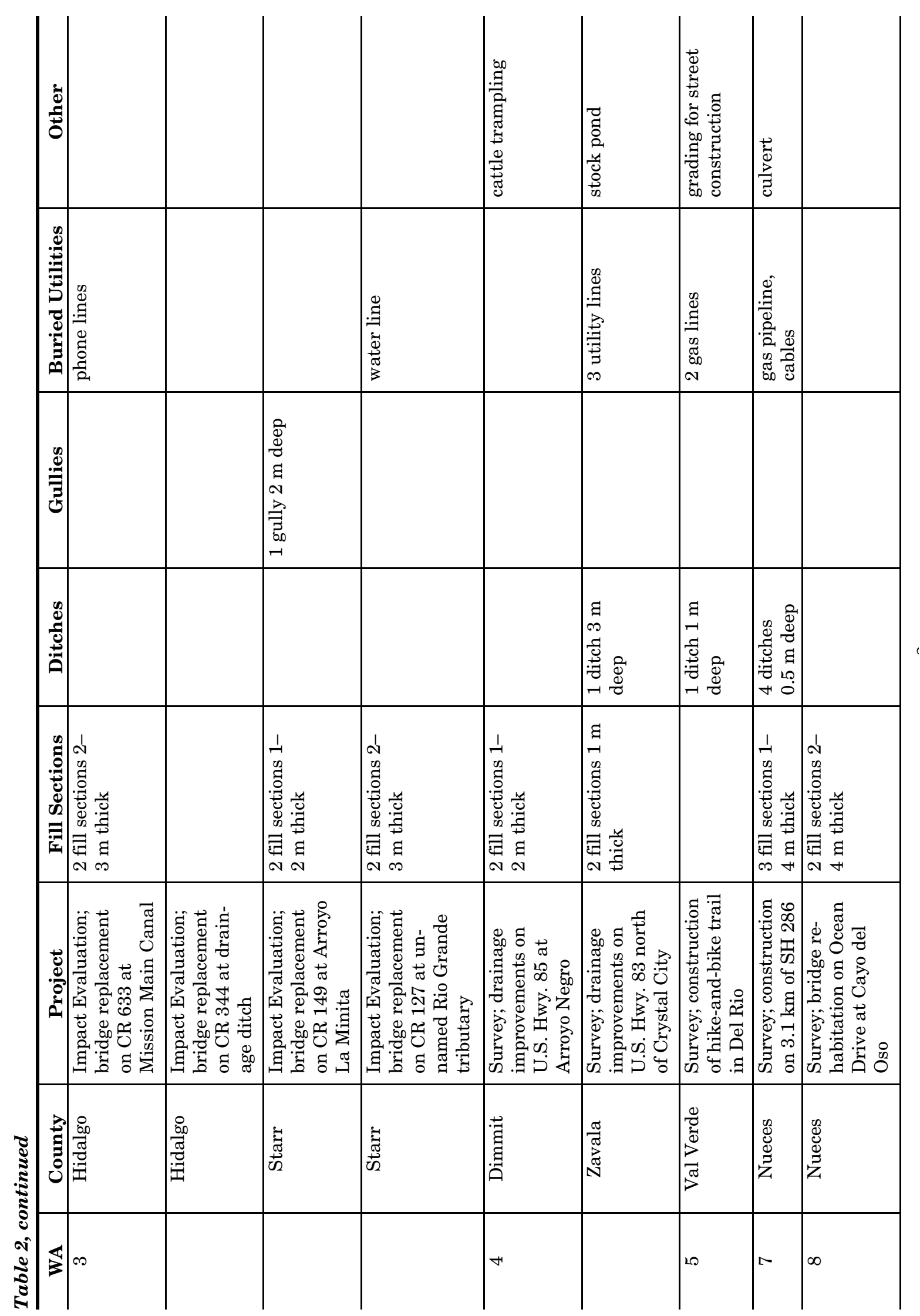


Chapter 3: Summary

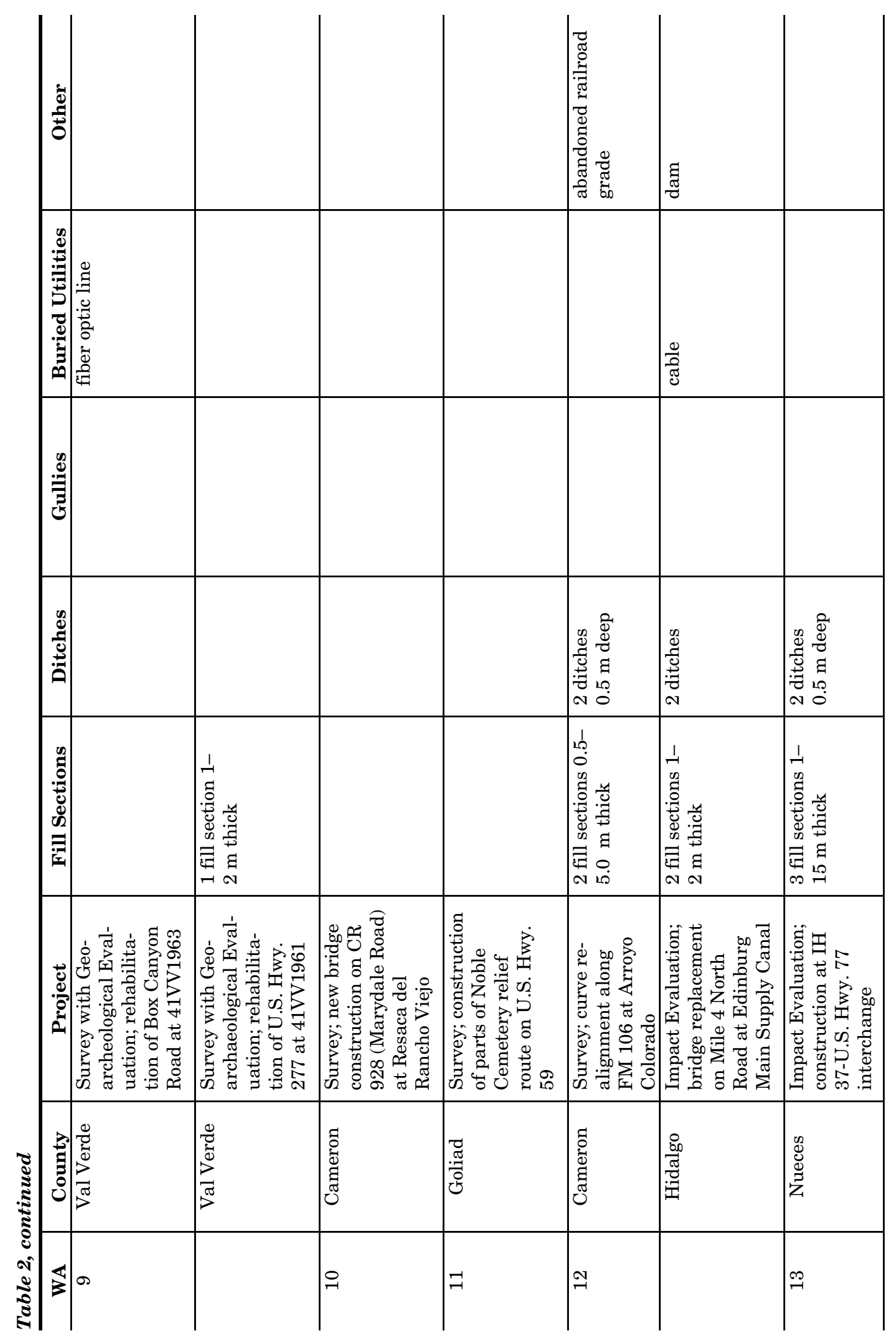


Archeological Impact Evaluations and Surveys

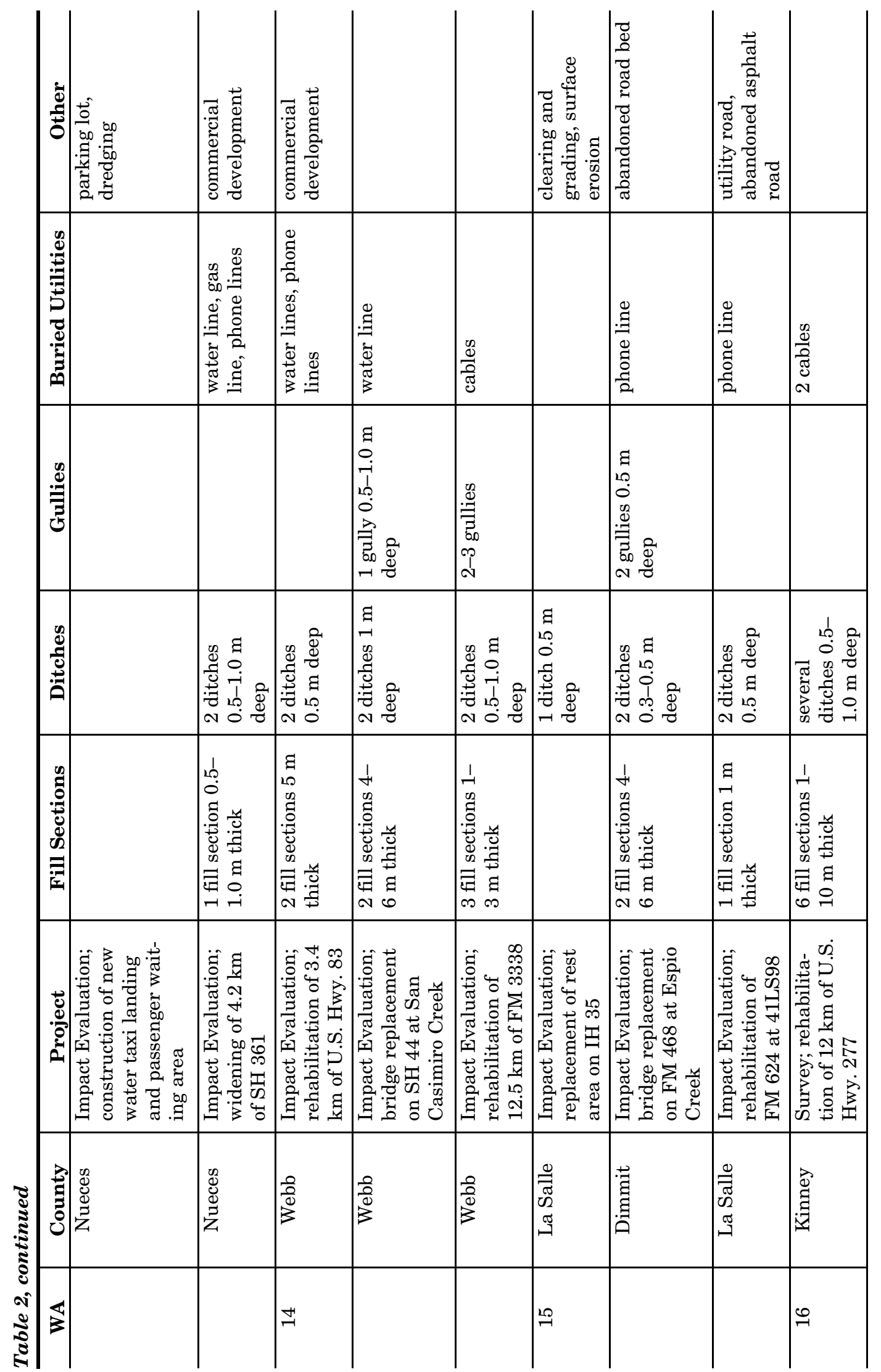


Chapter 3: Summary

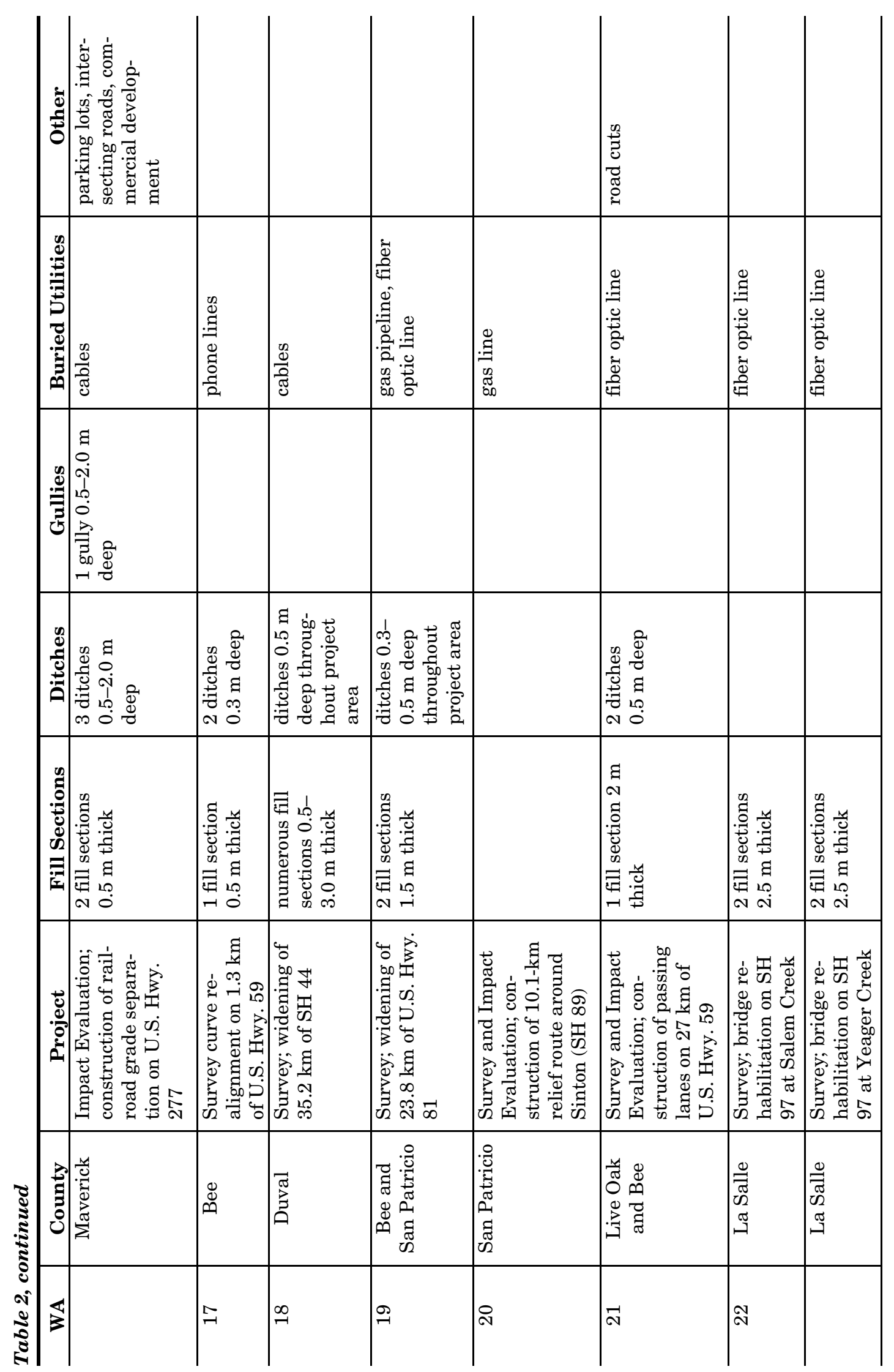


Archeological Impact Evaluations and Surveys

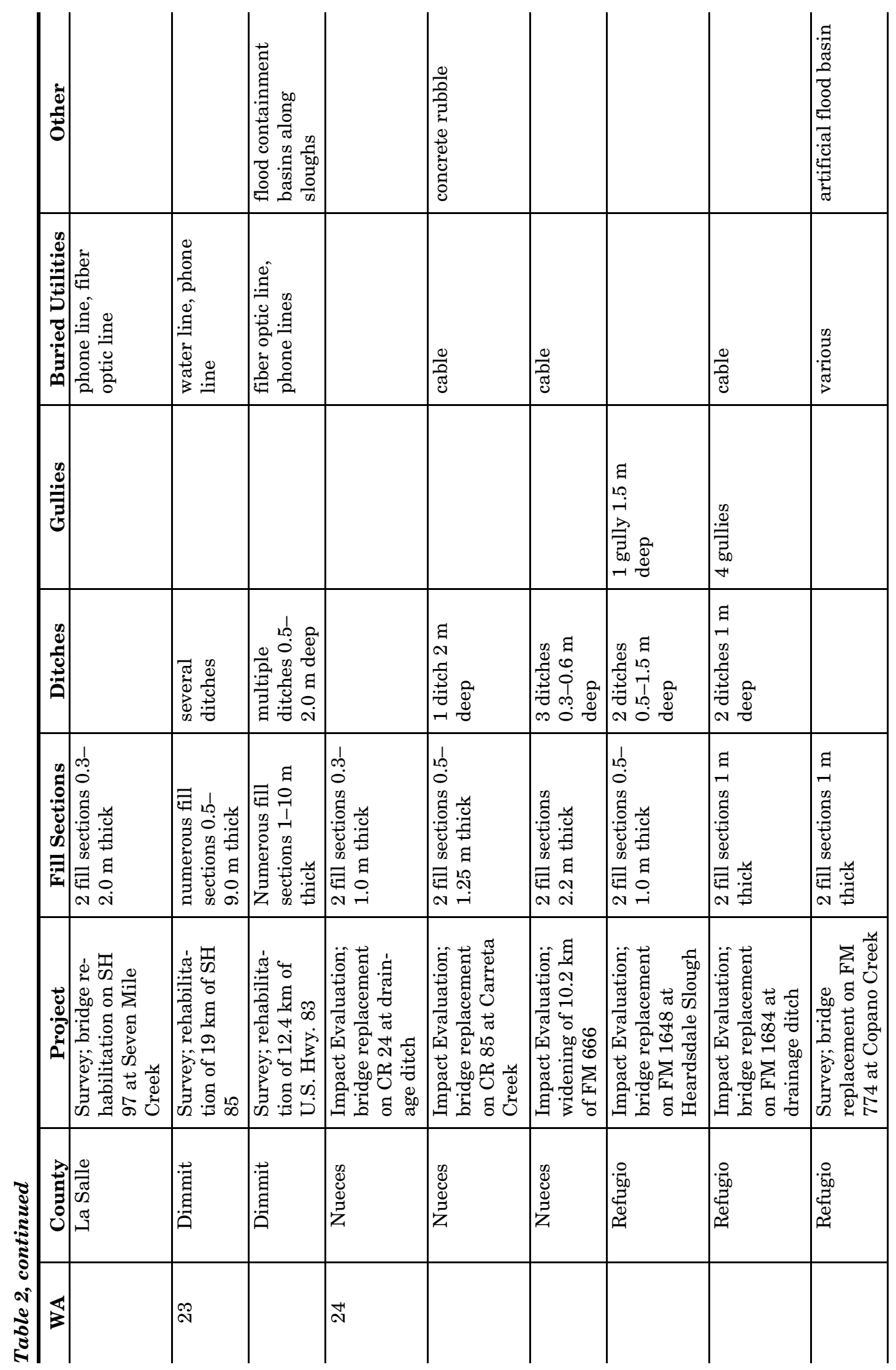


Chapter 3: Summary

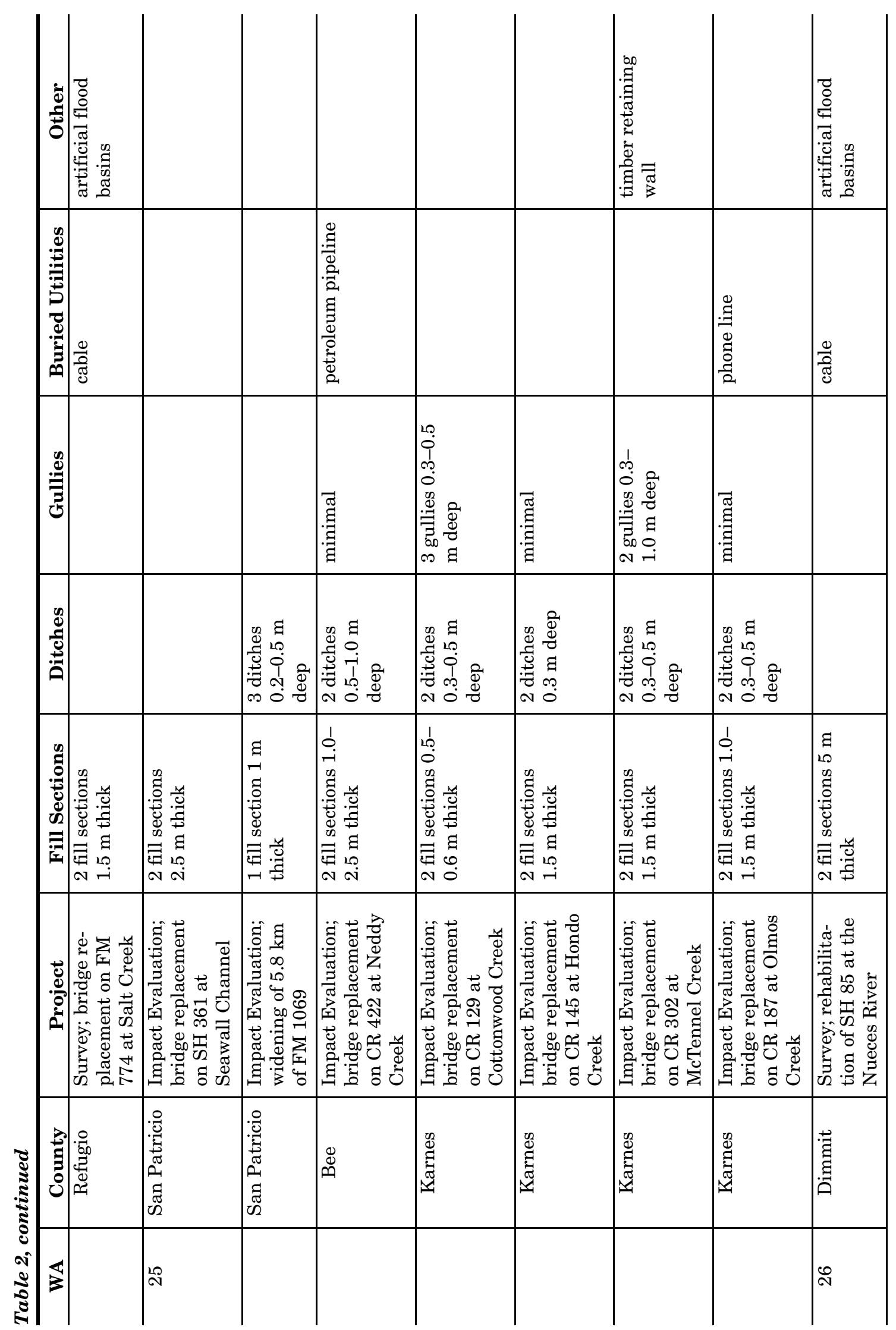




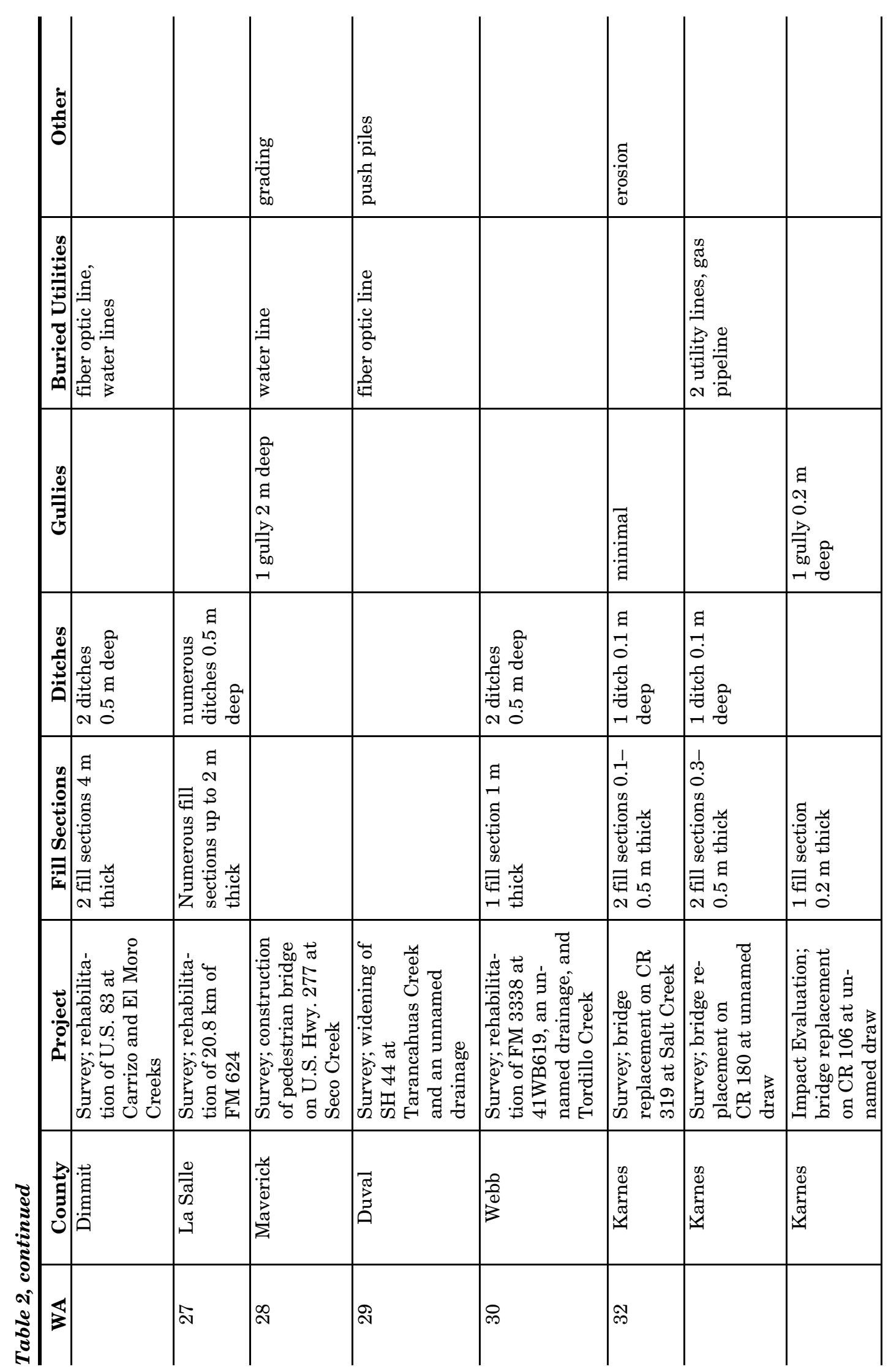


Chapter 3: Summary

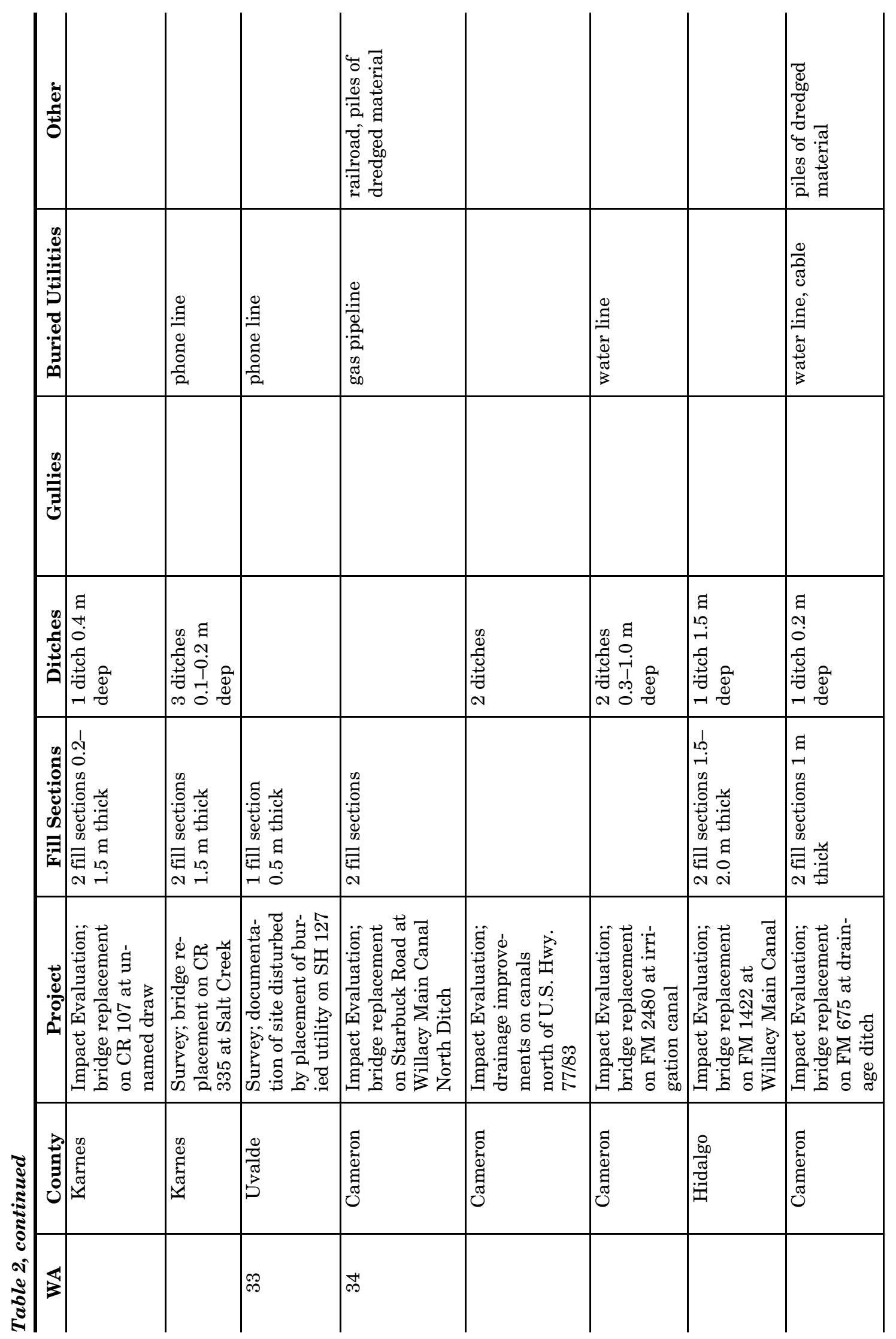


Archeological Impact Evaluations and Surveys

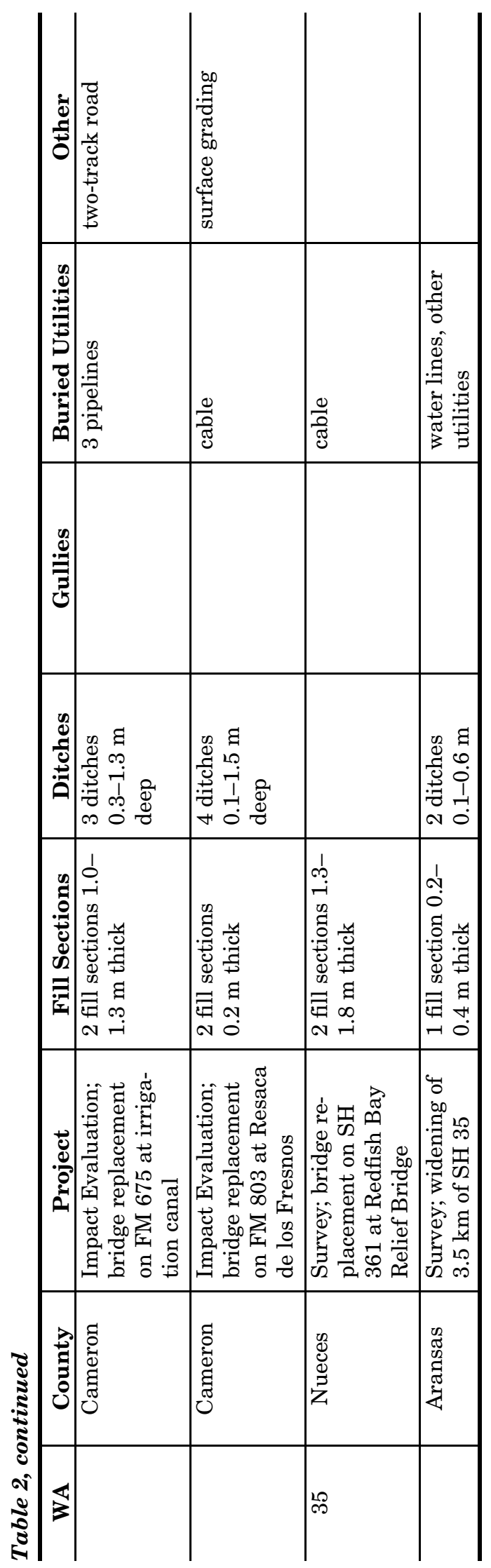




\section{SITES INVESTIGATED}

Twenty-six archeological sites were investigated during 14 work authorizations. At 9 previously recorded sites, no archeological remains were observed. In all but 2 of these 9 cases, work was restricted to existing rights of way; in some, only general site locations were known, and the actual proximity of the sites to the Transportation Activities could not be determined. Archeological remains were observed at the remaining 17 sites, most often in existing right of way $(\mathrm{n}=$ 13) and less commonly in new right of way or easements $(n=4)$. Descriptions of these sites, drawn from the original reports included on CDROM in Appendix B, are presented below. Table 3 summarizes the materials observed and recommendations made.

\section{Work Authorization 4: 41DM150}

Site 41DM150 was recorded during a survey of three proposed drainage easements at Arroyo Negro along U.S. Highway 85 in Dimmit County. Artifacts were observed while accessing the eastern side of the project area within a broad area of good visibility located approximately $70-100 \mathrm{~m}$ south of U.S. Highway 85 and 100-150 m east of Arroyo Negro. Subsequent pedestrian survey revealed that the scatter of surface artifacts continues west to the margins of the nearest stream channel and extends throughout the $15 \times 150-\mathrm{m}$ section of proposed easement along the east bank of the easternmost channel of Arroyo Negro. Four trenches were placed along the eastern bank of the channel, and artifacts were observed in the uppermost soil zone to a depth of $30 \mathrm{~cm}$. Artifacts observed on the surface and in the trenches included chert flakes, cores, tested cobbles, biface fragments and other tools, and a single sidenotched point with basal notch identified as a Late Archaic Frio point. Small (1 cm diameter) lumps of burned clay also were discovered in Trench 6 and may indicate cultural features (hearths?), although no intact features were observed. No artifacts were observed on the surface nor in shovel tests west of the eastern stream channel, and, thus, this channel marks the western boundary of the site.

The full extent of 41DM150 remains unknown. Minimally, the site measures $150 \times 150 \mathrm{~m}$. Because of the nearly surficial char- acter of the site, it is highly likely that erosion and redeposition as well as bioturbation have severely disturbed these archeological deposits, particularly within the project area. Furthermore, most of 41DM150, including the densest concentration of artifacts observed, lies outside the current project area and will not be affected by the proposed drainage improvements along Arroyo Negro. Finally, the large size of this site suggests a formation history comprising repeated, overlapping occupations, probably resulting in a mixing and blurring of discrete components and lessening the site's potential interpretive significance. It appears that $41 \mathrm{DM} 150$, especially that portion within the current project area, contains archeological deposits that lack integrity sufficient to make it eligible for designation as a State Archeological Landmark or listing in the National Register of Historic Places.

\section{Work Authorization 4: 41ZV344}

Previously recorded site 41ZV344 was investigated during a survey of proposed drainage improvements along U.S. Highway 83 in Zavala County. This site was first recorded by TxDOT personal in 1995, who noted sparse lithic materials extending for ca. $27 \mathrm{~km}$ along U.S. Highway 83 between Crystal City and a Pryor. About $1 \mathrm{~km}$ of this length was included in the Work Authorization 4 survey area, all in existing right of way, along with an adjacent 0.3$\mathrm{km}$-long easement extending west from U. S. Highway 83. A very sparse scatter of lithic artifacts was observed on the surface and in a few of the five trenches and six shovel tests dug in this area, and this scatter presumably relates to $41 Z V 344$. The few types and very low densities of artifacts encountered do not indicate sustained human occupation or use of this locale, however. Rather, the very diffuse scatter of lithic artifacts observed is probably quite typical of this zone of uplands close (ca. $2 \mathrm{~km}$ ) to the Nueces River valley. Future archeological work along the U.S. Highway 83 corridor between Crystal City and La Pryor and in adjacent lands will undoubtedly document similar low-density areas (as well as high-density areas) within the purported confines of 41ZV344.

The nearly surficial character of the archeological deposits at 41ZV344, the absence of chronologically diagnostic remains, and the evidence 
Table 3. Summary of archeological sites investigated

\begin{tabular}{|c|c|c|c|}
\hline WA & Site & Materials Observed & Recommendation \\
\hline 4 & 41DM150 & debitage, biface, cores & no further work \\
\hline 4 & $41 Z \mathrm{~V} 344$ & debitage, tested cobbles, cores & no further work \\
\hline 7 & $41 \mathrm{NU} 254$ & none & no further work \\
\hline 9 & 41VV1963 & burned rocks, debitage & no further work \\
\hline 9 & 41VV1961 & $\begin{array}{l}\text { debitage, dart points, uniface, cores, animal } \\
\text { bones }\end{array}$ & eligible \\
\hline 14 & 41WB17 & none & no further work \\
\hline 14 & 41WB18 & none & no further work \\
\hline 14 & 41WB214 & none & no further work \\
\hline 14 & $41 \mathrm{WB} 456$ & debitage & no further work \\
\hline 14 & $41 \mathrm{WB} 457$ & debitage & no further work \\
\hline $14 / 30$ & 41WB619 & debitage & no further work \\
\hline 14 & 41WB620 & debitage & no further work \\
\hline $15 / 27$ & 41LS98 & debitage, burned chert, burned rock & no further work \\
\hline 16 & $41 \mathrm{KY} 13$ & debitage, cores, burned rocks & no further work \\
\hline 16 & $41 \mathrm{KY} 28$ & debitage & no further work \\
\hline 16 & $41 \mathrm{KY} 51$ & none & no further work \\
\hline 16 & 41MV57 & none & no further work \\
\hline 16 & 41MV58 & none & no further work \\
\hline 20 & 41SP99 & debitage & no further work \\
\hline 21 & 41LK11 & debitage, cores & no further work \\
\hline 23 & 41DM3 & none & no further work \\
\hline $23 / 26$ & $41 \mathrm{DM} 49$ & burned rocks, mussel shells & no further work \\
\hline 23 & 41DM4 & none & no further work \\
\hline 26 & 41DM151 & $\begin{array}{l}\text { burned rocks, mussel shells, debitage, } \\
\text { charcoal }\end{array}$ & test excavations \\
\hline 33 & 41UV444 & $\begin{array}{l}\text { midden debitage, burned rocks, tested } \\
\text { cobble, cores }\end{array}$ & no further work \\
\hline 35 & 41AS27 & shell midden & no further work \\
\hline
\end{tabular}

for extensive disturbances throughout the project area limit the significance of these materials. Landscape modifications associated with the proposed drainage improvements along this section of U.S. Highway 83 north of Crystal City will not threaten cultural resources eligible for designation as State Archeological Landmarks or listing in the National Register of Historic Places.

\section{Work Authorization 7: 41NU254}

Site 41 NU254 is the location of a previously recorded historic grave that was reportedly just east of the existing right of way of State Highway 286 south of Oso Creek in Nueces County. The site was recorded by personnel with the Corpus Christi Museum based on an informant's report, which stated that a single grave dating to ca. 1885 had been disturbed by earthmoving and that other graves were likely present. The existing right of way in this area was investigated during a survey for an extension of State Highway 286. An access road to a private residence marks the general area of 41NU254 in the eastern portion of the right of way, and survey determined that the configuration of the road cut and ditch that adjoin the site area, as well as the presence of an underground gas pipeline, make it very unlikely that other graves remain intact within the existing right of way. But if new right of way is obtained in the area under future Transportation Activities, additional survey to look for unmarked graves should be done.

\section{Work Authorization 9: 41VV1963}

Previously recorded site 41VV1963 was investigated through intensive survey-level effort to gather information to assess whether it mer- 
its more-intensive testing to determine its National Register of Historic Places and State Archeological Landmark eligibility. The work was done under Work Authorization 9 in connection with upgrading Box Canyon Road in Val Verde County from an unpaved caliche road to a paved two-lane road. The site was recorded originally in 2003 as an open prehistoric campsite with a possible Middle Archaic component (Houk and Skoglund 2003). It appeared to measure $110 \mathrm{~m}$ north-south by at least $50 \mathrm{~m}$ eastwest, extending outside the existing right of way to the west and possibly to the east as well. It was noted that a buried fiber optic line traverses the site, paralleling the road ca. $15 \mathrm{~m}$ to the east. Burned rock fragments were observed in the road-grading spoil piles along the edge of the road and scattered across the site's surface. One burned rock feature (Feature 2) was noted on the surface approximately $30 \mathrm{~m}$ west of the right of way. Other cultural materials observed on or collected from the surface consisted of a possible Almagre point and two chert flakes. Subsurface investigations consisted of the excavation of three Gradall trenches. Two additional burned rock features were encountered in the trenches. One was a slab hearth (Feature 1) associated with one chert flake approximately $3 \mathrm{~cm}$ below surface, and the other was a partially exposed burned rock hearth (Feature 3) associated with a large primary flake approximately $5-10 \mathrm{~cm}$ below the surface. The cultural deposits were estimated to be $15 \mathrm{~cm}$ thick based on trench profile observations.

The current investigations consisted of pedestrian survey of the site area, the manual excavation of six $0.5 \times 0.5-\mathrm{m}$ test units, and the excavation of four trenches. The pedestrian survey of the site area noted a burned rock feature west of Box Canyon Road and scattered burned rock fragments within the road-grading spoil piles along the edge of the road. Few other cultural materials were observed on the surface, save for three chert flakes, one biface fragment, and a few burned rocks. The four trenches were $1.6 \mathrm{~m}$ wide and varied from 4.4 to $4.9 \mathrm{~m}$ in length and 0.45 to $1.05 \mathrm{~m}$ in depth. The trench profiles revealed that the site is mantled by a Holoceneage pale brown silt loam of varying gravel content (10-50 percent) and varying thickness $(<20$ to $105 \mathrm{~cm}$ ). The silty mantle overlies weathered limestone bedrock and appears to have accumulated through sheetwash and eolian processes.
No cultural materials were observed in the trench profiles. Three of the six test units (Test Units 1, 3, and 4) were placed adjacent to three of the four trenches, but Test Units 2, 5, and 6 were isolated units. Placement of test units adjacent to the trenches focused on those areas of the site where the Holocene mantle was thickest and of relatively low gravel content. Excavation depths ranged from 19 to $95 \mathrm{~cm}$ below the surface before encountering bedrock. The test units were excavated in $10-\mathrm{cm}$ levels, and the matrix screened totaled $0.71 \mathrm{~m}^{3}$. In total, five chert flakes were recovered from the test units. The five pieces of lithic debitage came from the following test units and levels: Test Unit 1, Level 1; Test Unit 2, Levels 1 and 2; Test Unit 5, Level 1; and Test Unit 6, Level 1. The distribution suggests that the cultural deposits at $41 V V 1963$ are shallow and no more than $20 \mathrm{~cm}$ thick, which is consistent with what Houk and Skoglund (2003) noted for the site.

Road construction and the installation of a fiber optic line have disturbed the site. In addition, the natural processes of erosion, particularly sheetwash, have taken their toll, and the paucity of artifacts, their shallow context, and the observation of few artifacts on the surface suggest that the available data sets are too limited for the site to contribute to our understanding of the prehistory of the area. Site 41VV1963 is judged ineligible for listing in the National Register of Historic Places and designation as a State Archeological Landmark.

\section{Work Authorization 9: 41VV1961}

Previously recorded site 41VV1961 also was investigated under Work Authorization 9 to assess whether it merits more-intensive testing to determine its National Register of Historic Places and State Archeological Landmark eligibility. The work was done in connection with planned rehabilitation of U.S. Highway 277, with all work restricted to the existing right of way. The site was recorded in 2002 as lying north of Sycamore Creek along the west side of the highway between the bridge fill section and an access road from the highway to a roadside park (Carpenter et al.2002). The site occupies a broad, nearly level Holocene terrace of Sycamore Creek, a prominent tributary of the Rio Grande. The site was recorded as an open prehistoric 
campsite of unknown temporal affiliation measuring $100 \mathrm{~m}$ north-south by at least $40 \mathrm{~m}$ eastwest. The site area had been disturbed by construction of both U.S. Highway 277 and the park road. Carpenter et al. (2002) excavated four shovel tests to depths ranging from 70 to $100 \mathrm{~cm}$. Cultural materials, 53 flakes and 5 burned rocks, were recovered from all four shovel tests. In Shovel Test 3, cultural materials were recovered from all levels down to $100 \mathrm{~cm}$, but materials were notably more abundant from 60 to $80 \mathrm{~cm}$. They also noted the possible presence of a burned rock feature in this level, though the limited exposure made it difficult to determine the nature of the feature. Based on the results of shovel testing, Carpenter et al. (2002) suggested that the site contains cultural deposits $100 \mathrm{~cm}$ thick or more.

The current investigations consisted of pedestrian survey of the site area, the manual excavation of five $0.5 \times 0.5-\mathrm{m}$ test units, and the excavation of five trenches. The pedestrian survey of the site area noted lithic debitage and a few burned rocks scattered across the site's surface. Disturbances appeared to be minimal and limited to the surface and near surface $(<20 \mathrm{~cm})$. The trench profiles revealed late Holocene alluvium exhibiting a moderately developed soil. Trenches closest to Sycamore Creek displayed a mantle 8-29 cm thick of recent (historic) alluvium capping earlier fill. Cultural materials, primarily burned rocks, were observed in four of the five trench profiles. Isolated burned rocks or lenses of burned rocks were observed at $88 \mathrm{~cm}$ below the surface in one trench, 80 and $115 \mathrm{~cm}$ in one trench, 104 and $115 \mathrm{~cm}$ in one trench, and 50 and $105-130 \mathrm{~cm}$ in one trench. A 0.5 x0.5$\mathrm{m}$ test unit was placed adjacent to each of the five trenches. The five test units were excavated in 10-cm levels, and the volume of matrix manually excavated and screened totaled $1.53 \mathrm{~m}^{3}$. The depths of the test units ranged from 80 to $160 \mathrm{~cm}$. Prehistoric cultural materials were recovered from four of the five units and consist of 2 dart points, 2 biface fragments, 3 unifacial tools, 1 core, 387 pieces of lithic debitage, 1 possible ground stone tool, 2 burned rock features, 1 deer phalanx, 186 burned rocks, and many pieces of charcoal. All but 1 piece of lithic debitage was recovered from Test Units 2-4, with the highest number of flakes coming from $60-80 \mathrm{~cm}$ in Test Unit $2(\mathrm{n}=54$, or 32 percent of the test unit total), $90-110 \mathrm{~cm}$ in Test Unit 3
( $\mathrm{n}=64,37$ percent), and $80-90$ and $100-110 \mathrm{~cm}$ in Test Unit 4 ( $\mathrm{n}=22,49$ percent). One of the dart points is a Frio, recovered from $70-80 \mathrm{~cm}$ in Test Unit 2, while the other is an untyped, broad-bladed point from $90-100 \mathrm{~cm}$ in Test Unit 3. A third similar broad-bladed dart point fragment (cf. Castroville, Marcos) was collected from the backdirt of Trench 3. The two features are small burned rock features, possibly hearths, encountered at $67 \mathrm{~cm}$ in Test Unit 2 and $50-60 \mathrm{~cm}$ in Test Unit 4. Both features contained copious charcoal.

The investigations at 41VV1961 recovered cultural materials in discrete contexts from a deposit that is at least $150 \mathrm{~cm}$ thick. Excavations yielded chronological as well as other data that suggest 41VV1961 has a high research value. Site 41VV1963 is recommended as being eligible for listing in the National Register of Historic Places and designation as a State Archeological Landmark.

\section{Work Authorization 14: $41 \mathrm{WB} 17$ and $41 \mathrm{WB} 18$}

Previously recorded sites $41 \mathrm{WB} 17$ and 41WB18 are located adjacent to a section of U.S. Highway 83 in Laredo, which was subjected to impact evaluation because of proposed rehabilitation of the highway within existing right of way. Both sites occupy terraces of the Rio Grande on the west side of the highway. Site $41 \mathrm{WB} 17$ was recorded in 1979 by W. H. Whitsett and D. E. Fox of the Texas Water Development Board as a surface artifact scatter containing chert flakes, burned rocks, and mussel shells (Fox and Whitsett 1979). Site 41WB18 also was recorded in 1979 by Whitsett and Fox. Located ca. $100 \mathrm{~m}$ west of U.S. Highway 83, the site consisted of lithic debitage and mussel shells located on the ground surface and along arroyo slopes. Articulated bone was recorded at ca. $3 \mathrm{~m}$ deep along an arroyo slope. Both sites were subsequently tested by the Center for Archaeological Research at The University of Texas at San Antonio (McGraw 1983). Intensive testing revealed limited intact deposits associated with either site, and no further work was recommended.

Impact evaluation revealed that the right of way and adjacent lands in the vicinity of $41 \mathrm{WB} 17$ and $41 \mathrm{WB} 18$ have been severely disturbed by construction and maintenance of U.S. Highway 83, placement of fill sections, ex- 
cavation of drainage ditches, placement of buried utilities, and construction of intersecting roadways, sidewalks, asphalt parking lots, residential complexes, and commercial developments. The plotted locations of the sites are completely built over, and no trace of either site was observed in the thoroughly disturbed existing right of way.

\section{Work Authorization 14: 41WB214, 41WB456, and $41 \mathrm{WB} 457$}

Previously recorded sites 41WB214, 41WB456, and 41WB457 are located along a stretch of FM 3338 in Webb County that was subjected to impact evaluation because of proposed rehabilitation of the highway within existing right of way. Site 41WB214, recorded in 1990 by TxDOT personnel, is located at the southern end of the project area at the intersection of FM 3338 and FM 1472. This site is an extensive lithic scatter located within thin $(5 \mathrm{~cm})$, gravelly, sandy soils atop bedrock. The site apparently was revisited in 1997 by personnel with Geo-Marine, Inc., during a survey for the U.S. Army Corps of Engineers, at which time it was described as a "low-density lithic scatter with several small low-density concentrations." Sites 41 WB456 and 41WB457 were recorded just north of $41 \mathrm{WB} 214$ within the existing right of way and beyond onto private property in a 1997 survey for the Texas Water Development Board by personnel with TRC Mariah Associates, Inc. These are open campsites containing lithic debris including flakes, angular debris, tested cobbles, and cores scattered amongst natural gravels on a broad upland surface. No diagnostic tools were observed. Both sites lack subsurface deposits and were considered to have no potential to contain important information. Both sites also apparently were revisited by archeologists with Geo-Marine in 1997.

The part of 41WB214 within the existing right of way has been completely disturbed by roadway construction. Road cuts ca. $3 \mathrm{~m}$ deep are present throughout the entire site location on both sides of the roadway. Evidence of gravel borrowing is present throughout the area as well. No artifacts associated with this site were observed. In contrast, scattered lithics were observed in road cuts and on the surface in the areas of 41WB456 and 41WB457. Only narrow strips of relatively undisturbed right of way are present at these locations, however. Based on these factors and the surficial nature of the cultural deposits atop upland landforms, it appears that all three sites lack integrity, have no capacity to contribute important information, and are not eligible for listing in the National Register of Historic Places or designation as State Archeological Landmarks.

\section{Work Authorizations 14 and 30: $41 \mathrm{WB} 619$ and $41 \mathrm{WB} 620$}

Two new sites-41WB619 and 41WB620also were located and recorded during the Work Authorization 14 impact evaluation on FM 3338 in Webb County, with 41 WB620 being the scene of follow-up survey investigations under Work Authorization 30. Site 41WB619 is located on the east side of FM 3338 on an upland landform north of an unnamed tributary to Santa Isabel Creek. The site was first encountered along a ca. 1-m-deep road cut and a drainage ditch, where chert flakes, burned limestone, and two biface fragments were found scattered for ca. $130 \mathrm{~m}$ north-south along the roadway. The site extends an unknown distance eastward onto private property. Four shovel tests were excavated within the boundary of the site in the existing right of way. These tests averaged between 50 and $70 \mathrm{~cm}$ deep, and bedrock was struck in each test. The sediments removed were shallow and consisted of a gravelly sandy silty clay. No cultural materials were encountered in any of these tests, and thus the site appears to be restricted to the surface. Construction and maintenance of FM 3338 have disturbed most of the right of way at this location. Because of disturbance and the lack of subsurface deposits, 41WB619 appears to have no capacity to contribute important information and thus is ineligible for National Register of Historic Places listing or State Archeological Landmark designation.

Site 41WB620 is located on the upland surface on the west side of FM 3338. It consists of an extensive (ca. $170 \mathrm{~m}$ north-south) but sparse lithic scatter containing primarily chert flakes; it probably extends westward onto private property. Positioned along the graded U.S. Border Patrol road and drainage ditch bordering FM 3338, most of the part of the site within the existing right of way has been disturbed. 
Because of this and the upland setting, no shovel tests were dug. As with 41WB619, it has no capacity to yield important information because it is restricted to the surface and is disturbed. It is not eligible for National Register listing or State Archeological Landmark designation.

\section{Work Authorizations 15 and 27: 41LS98}

Previously recorded site 41LS98 was investigated through impact evaluation and survey in connection with planned rehabilitation of FM 624 within existing right of way in La Salle County. The site was recorded in 2000 by an avocational archeologist, who noted that it was a lithic scatter with debitage and tools along with some Rabdotus shells situated atop a knoll that FM 624 crossed. Most of the site is on private property east of the highway, with a smaller portion extending west of the highway.

The right of way at 41LS98 has been severely disturbed by fill placement, roadway construction, road cuts, a utility road, drainage ditches, and the placement of buried and overhead utility lines. Fill up to $1 \mathrm{~m}$ thick is present in the central portion of the site. North and south of this, the road is at grade or positioned in 1-mdeep road cuts. The surface and subsurface deposits have been graded and sloped toward the roadway, exposing large sections of gravelly fill and several bedrock exposures. A two-track utility road runs east-west through the central portion of the site. A buried phone cable marks the eastern boundary of the right of way. Power poles have been placed along the east side of the road. Portions of an old asphalt roadway are present along the eastern side of the project area. Construction associated with each of these activities has severely disturbed the deposits containing 41LS98 within the existing right of way.

Eleven shovel tests were placed inside the existing right of way within the site boundaries. These tests ranged between 45 and $100 \mathrm{~cm}$ deep. Sediments removed from the tests varied. Some tests revealed a dense gravelly clay fill associated with construction, and other tests revealed sandy silty clay to silty sandy loam and gravelly sandy silty loam. The zone of water saturation was struck in four shovel tests between 80 and $95 \mathrm{~cm}$. Cultural materials were present in four shovel tests between 20 and $60 \mathrm{~cm}$. These consisted of 4 pieces of burned chert, 14 pieces of debitage, and 1 burned rock. The sediments containing the cultural materials consisted of a sandy silty clay with abundant gravels.

Most of the site within the existing right of way has been severely disturbed. Much of the right of way at the site has been graded and sloped, removing most of the deposits associated with the site. Artifacts were found in only four shovel tests, with the remaining tests showing dense construction fill. Since most of the deposits containing 41LS98 within the existing right of way have been removed, the site has little capacity to yield important information and is ineligible for listing in the National Register of Historic Places or designation as a State Archeological Landmark.

\section{Work Authorization 16: 41KY13, 41KY28, and 41KY51}

Previously recorded sites 41KY13, 41KY28, and $41 \mathrm{KY} 51$ were investigated during survey for rehabilitation of a stretch of U.S. Highway 277 within existing right of way in Kinney County. Site $41 \mathrm{KY} 13$ is located on the south bank of Sycamore Creek in the U.S. Highway 277 right of way and on private land to the west. The original site form is missing, and thus no information about its original recording is available. Sites $41 \mathrm{KY} 28$ and $41 \mathrm{KY} 51$ are on the upland slopes north of Pinto Creek. Site 41KY28 was recorded by SDHPT (now TxDOT) personnel in 1986 as a scatter of flakes and burned rocks ca. $150 \mathrm{~m}$ north of Pinto Creek. Most of the site lay west of the highway, with only a small part extending into the western right of way. The recorder suggested that shallowly buried middens and hearths could be present, presumably in the less-disturbed areas west of the highway right of way. Site 41KY51 is located on the east side of the highway ca. $250 \mathrm{~m}$ north of Pinto Creek near the apex of a hill overlooking both Goat Creek to the north and Pinto Creek to the south. The original site form is missing, and thus no other information is available.

The existing right of way at all three sites was examined, and archeological materials were observed at 41KY13 and 41KY28. At 41KY13, a dense lithic scatter consisting of flakes, cores, and burned limestone was noted on the surface in the western right of way south of Sycamore Creek. Most of the site in this area has been 
removed by the excavation of a large, ca. 10x30$m$ drainage ditch that stretches from the western boundary of the right of way ca. $50 \mathrm{~m}$ west to private property. Two narrow strips of land on each side of the ditch ca. $5 \mathrm{~m}$ wide are all that remain of the original landform. Four shovel tests were placed along one strip just inside the right-of-way boundary. The tests were excavated to depths of 72-100 cm and contained a compact silty clay. All sediments excavated were screened through 1/4-inch-mesh hardware cloth. No cultural materials were recovered from any of the shovel tests. Examination of the cutbanks along the large ditch also did not identify any buried cultural deposits. These efforts illustrate that no intact portions of $41 \mathrm{KY} 13$ exist within the right of way, and thus the site has no capacity to contribute important information. It is ineligible for National Register listing or State Archeological Landmark designation.

Site $41 \mathrm{KY} 28$ on the west side of U.S. Highway 277 ca. $150 \mathrm{~m}$ north of Pinto Creek consists of a light lithic scatter in an area with shallow deposits and many bedrock exposures. Only three flakes were observed on the surface within the right of way, and no shovel tests were excavated because the sediments were thin. It is possible that more-intact deposits are present to the west on private property, as the original recorder noted, but this could not be confirmed by visual inspection across the fence line. Because the part of the site within the existing right of way has no subsurface deposits, it has no capacity to yield important information and is ineligible for National Register listing or State Archeological Landmark designation.

The location of $41 \mathrm{KY} 51$ near the apex of a tall hill on the east side of the highway consists entirely of bedrock exposures with only scattered shallow sediments. No evidence of the site was encountered during the survey, and it may lie entirely outside the right of way. Road cuts excavated for the highway have removed most of the upland surface in this area, leaving only a ca. 4-m-wide strip within the existing right of way. No artifacts were seen in this area despite good ground surface visibility.

\section{Work Authorization 16: 41MV57 and 41MV58}

Previously recorded sites 41MV57 and 41MV58 were investigated during an impact evaluation in existing and new right of way for construction of a railroad grade separation on U.S. Highway 277 in Eagle Pass. Site 41MV57 was recorded in 1979 by W. H. Whitsett of the Texas Water Quality Board and consisted of a surface scatter containing chert flakes, burned rocks, snail shells, and one rock-lined hearth. The site was mapped along a small terrace overlooking Seco Creek just south of U.S. highway 277. Site 41MV58 was also recorded in 1979 by Whitsett and was immediately east of and adjacent to 41MV57. This site consisted of two separate units. The first was a scatter of lithic debris, hearths, and snail shells located on the ground surface and along the slopes of an arroyo. The second unit consisted of a dense area of large gravels used as a quarry.

Impact evaluation revealed that the areas of 41MV57 and 41MV58 have been completely disturbed. The plotted location of 41WB57 now is a recently graded and leveled open lot. Evidence of heavy machine activity and gravel borrowing is present throughout the immediate area. The adjoining right of way has been completely graded down to form a steep slope leading to a ca. 2-m-deep drainage ditch. A large artificial water tank and associated canal separate the two sites. A large commercial building specializing in tire and automotive repair occupies the area where 41MV58 was located. The right of way here has also been sloped to form a 0.5-m-deep drainage ditch. A single buried wastewater pipeline runs east-west throughout the site area. No evidence of either site was found during the impact evaluation.

\section{Work Authorization 20: 41SP99}

Previously recorded site 41SP99 was investigated during survey for construction of a relief route around Sinton. It was recorded as an open campsite by personnel with The University of Texas at Austin in 1973, who noted lithic debris exposed along the north bank of Chiltipin Creek extending south from the MissouriPacific railroad tracks. Debitage, worked flint, projectile points, and burned clay were observed along the edges of several erosional draws. The site map depicts three spoil piles and four areas of lithic concentration paralleling Chiltipin Creek for a distance of ca. $1.6 \mathrm{~km}$.

The current survey involved inspecting the ca. 4-m-deep cut banks where the relief route 
crosses Chiltipin Creek and excavating seven shovel tests and eight backhoe trenches over distances of ca. $0.3 \mathrm{~km}$ south and $1.0 \mathrm{~km}$ north of the creek. Only six pieces of debitage were observed eroding out at the contact between the grassy mat and the highly eroded, disturbed north bank of the creek. The flakes were noted in a ca. 6-m-wide, ca. 20-m-long swath of land with excellent (90-100 percent) visibility. This stretch parallels the creek and has been disturbed by extensive erosion. Further, the creek has been dredged multiple times since 1942, and large piles of dredged materials parallel the creek banks. On the north bank of the creek, these piles are relatively low $(1.0-1.5 \mathrm{~m})$ but wide $(15 \mathrm{~m})$ and blend somewhat into the natural topography. To the south, the piles are both high (3-4 m) and wide (15 m).

The flat terrain north and south of the creek was sampled with shovel tests and trenches to determine if intact portions of 41SP99 extend away from the creek. Shovel tests were placed in open pastures on both sides of the creek. Visibility was poor over much of this area because of thick pasture grasses, dewberry vines, and wildflowers. Harvester ants have cleared many (20+) ca. 3-m-diameter circular areas that have improved visibility (100 percent), though. Shovel Tests 1-5 placed along the staked center line north of the creek ranged from 10 to $30 \mathrm{~cm}$ deep. Shovel Tests 1-4 exposed 10-25 cm of grayish brown sandy loam over grayish brown sandy clay with brown and yellowish brown mottles. Shovel Test 5 exposed $20 \mathrm{~cm}$ of very dark blackish gray sandy loam over $5 \mathrm{~cm}$ of very dark grayish brown sandy clay. No cultural materials were observed. Shovel Tests 6 and 7 were placed south of the creek and exposed $10 \mathrm{~cm}$ of very dark grayish brown sandy loam over very dark grayish brown sandy clay with light brown and yellowish brown mottles. No cultural materials were observed.

Eight backhoe trenches were excavated north and south of Chiltipin Creek on and close to 41SP99. Trenches 1-4 were placed in an open pasture north and south of a large spoil pile on the south side of Chiltipin Creek. Trenches 1 and 2 were along the proposed right of way center line. Trench 1 was ca. $230 \mathrm{~m}$ south of the creek, and Trench 2 was ca. $110 \mathrm{~m}$ north of Trench 1 and $30 \mathrm{~m}$ south of the large spoil pile. Trenches 3 and 4 were placed on a narrow (4$5 \mathrm{~m}$ ), level swath of land between the spoil pile and the creek. No artifacts were found in any of the trenches south of the creek, and the two closest to the creek showed evidence of multiple episodes of dredging.

Trenches 5-8 were placed on the north side of Chiltipin Creek. Trench 5 was $4 \mathrm{~m}$ north of the creek bank, Trench 6 was $12 \mathrm{~m}$ north of Trench 5 on a low $(1.0-1.5 \mathrm{~m})$ spoil pile, Trench 7 was $55 \mathrm{~m}$ north of Trench 6 and crossed over a spoil pile ending on the natural surface, and Trench 8 was $60 \mathrm{~m}$ north of Trench 7 . No cultural materials were observed in any of these trenches, including Trenches 5 and 6, which were in the immediate area of 41SP99.

The survey of the Chiltipin Creek area, including 41SP99, indicates that this area has been extensively disturbed, chiefly by dredging of the creek and erosion. Based on this disturbance, the thinness of the Holocene deposits, and the lack of cultural materials in any of the trenches and shovel tests, it appears that little, if any, of 41SP99 remains intact. Therefore, $41 \mathrm{SP} 99$ is considered to lack the capacity to provide important archeological information and is considered ineligible for listing in the National Register of Historic Places or designation as a State Archeological Landmark.

\section{Work Authorization 21: 41LK11}

Previously recorded site 41LK11 was investigated during a survey for construction of passing lanes in existing right of way on U.S. Highway 59 between Interstate Highway 37 and Beeville in Live Oak and Bee Counties. The site was recorded by THD (now TxDOT) personnel in 1975 as a prehistoric artifact scatter following a ridge that U.S. Highway 59 crosses ca. 270 $450 \mathrm{~m}$ west of Hailey Hollow. The recorder collected a biface, an expanding-stem dart point, and lithic debitage from the site and reported that the site was restricted to the ridge top.

During the current survey, 30-40 flakes and 2 cores were observed on the disturbed surface of the southern right of way at the plotted site location. No artifacts were noted on the surface in the less-disturbed northern right of way, and eight shovel tests were placed there between the road cut and the right-of-way edge. The shovel tests were excavated in 20-cm levels and ranged from 30 to $55 \mathrm{~cm}$ deep. All sediments excavated were screened through 1/4-inch-mesh hardware cloth. Prehistoric artifacts were found in six 
shovel tests. In total, 11 flakes were noted, in addition to fire-cracked rocks and Rabdotus shells. Across the site, 3 pieces of debitage and 2 fire-cracked rocks were recorded at $0-20 \mathrm{~cm}$. Seven pieces of debitage and several fire-cracked rocks were observed at $20-40 \mathrm{~cm}$. Between 40 and $60 \mathrm{~cm}, 1$ piece of debitage and 3 small firecracked rocks were recorded. Rabdotus shells were numerous and were found in all three levels.

The portion of $41 \mathrm{LK} 11$ that is within the U.S. Highway 59 right of way has little capacity to contribute important information. Only very narrow strips of right of way remain beyond the road cut, and the archeological remains that are present in these strips are shallowly buried in upland contexts. The potential for isolating interpretable cultural remains is low. Hence, the part of the site in the existing right of way is not eligible for listing in the National Register of Historic Places or designation as a State Archeological Landmark.

\section{Work Authorizations 23 and 26: 41DM3 and 41DM49}

Two previously recorded sites-41DM3 and 41DM49-were investigated during a survey done under Work Authorization 23 for rehabilitation in existing right of way of a stretch of State Highway 85 in Dimmit County, with 41DM49 seeing a second episode of survey under Work Authorization 26. Site 41DM3 was recorded by Claud A. Bramblett of the Carrizo Springs High School Anthropology Club in 1958. The site is located in the western portion of the project area on eroded hillslopes near the Carrizo Springs airport. The site reportedly was visited by local artifact collectors for many years; two documented Folsom points are known to have come from the site. Site 41DM49 was recorded in 1966 by Thomas R. Hester. This site is located on the east bank of the Nueces River just north of the State Highway 85 right of way. It was recorded as a multicomponent site containing a variety of projectile points, including Montell and Ensor, and a variety of scrapers and knives. Abundant lithic debris and mussel shells were observed in gullies and eroded areas to a depth of ca. $1 \mathrm{~m}$.

The existing right of way at both sites was thoroughly inspected. Site 41DM3 is recorded along the slopes of a hill near the Carrizo
Springs airport. Road cuts ca. 1-2 m deep revealed shallow gravelly deposits overlying bedrock. Several shovel probes attempted in the area were unable to penetrate more than a few centimeters below the ground surface because of the dense gravels. All surface exposures were visually inspected for cultural materials, but none were observed. No intact deposits associated with 41DM3 remain in the right of way.

Site 41DM49 was recorded along the east bank of the Nueces River just north of the existing right of way. Most of the right of way at this location has been modified into a 1.0-1.5-m-deep flood containment basin, and further disturbance has resulted from the placement of buried utility lines along the edge of the right of way north of the road. Four trenches were placed in the right of way adjacent to 41DM49 to determine if any intact cultural deposits extend into this disturbed area. Trench 13 was placed ca. $5 \mathrm{~m}$ east of the river and immediately exposed a mixed fill consisting of concrete fragments, asphalt, and a large concrete encasement. Trenches 14 and 15 were placed ca. 75 and $100 \mathrm{~m}$ east of the river and contained four sediment zones. Zone 1 was $20-25 \mathrm{~cm}$ thick and consisted of silty clay. Zone 2 was $50 \mathrm{~cm}$ thick in both trenches and consisted of silty sandy loam. Zone 3 was located between 70 and $130 \mathrm{~cm}$ in Trench 14 and 110 and $170 \mathrm{~cm}$ in Trench 15 and consisted of silty clayey loam. Zone 4 was observed only in Trench 14 and was present down to $160 \mathrm{~cm}$. It consisted of a gravelly silty clay channel deposit. The gravel ranged in size from $2 \mathrm{~cm}$ up to $8 \mathrm{~cm}$, and most were well rounded. A few burned rocks and mussel shells were lightly scattered in Zone 2, but no accumulations or patterning were observed. For the most part, it appears that the deposits containing 41DM49 within the existing right of way have been completely removed and disturbed. Trench 16 was placed ca. 75 m east of Trench 15 inside a modified flood basin. This trench revealed silty loam to silty clay loam throughout the $185-\mathrm{cm}$ profile. No cultural materials were encountered in this trench.

To determine whether associated cultural deposits are in the right of way south of the road across from the plotted location of 41DM49, three shovel tests and three trenches were placed in this area. A large fill section occupies the entire right of way from the river east approximately $100 \mathrm{~m}$, and the trenches were east 
of this fill section. The shovel tests were farther east still. No cultural materials were encountered in any of these trenches or tests, and thus the site does not extend south of State Highway 85 . Survey in the area of 41DM49 revealed that most of the cultural deposits associated with this site within the existing right of way have been disturbed or removed. Hence, this part of the site does not have the capacity to yield important information and is ineligible for listing in the National Register of Historic Places or designation as a State Archeological Landmark.

\section{Work Authorization 23: 41DM4}

Previously recorded site 41DM4 was investigated during a survey for rehabilitation of U.S. Highway 83 in existing right of way just southeast of Carrizo Springs in Dimmit County. This site was recorded by Claud A. Bramblett of the Carrizo Springs High School Anthropology Club in 1958 as a lithic scatter containing dart and arrow points in a plowed field on U.S. Highway 83 southeast of Carrizo Creek. The existing right of way at the plotted site location was examined during the current survey and found to be an upland slope containing shallow gravelly deposits that allowed for excellent surface visibility. Shovel probes were ineffective due to the dense gravels. Road cuts provided good exposures of the subsurface deposits, which consisted of gravelly sediments overlying shallow bedrock. No evidence of the site was encountered inside the existing right of way.

\section{Work Authorization 26: 41DM151}

Site 41DM151 was recorded during a survey for rehabilitation of State Highway 85 in existing right of way just west of the Nueces River in Dimmit County. Cultural materials were observed in 4 of the 12 trenches excavated on the Nueces floodplain west of the river during this survey. Cultural materials consisted of sparse chert debitage intermixed with numerous mussel shells and scattered burned rocks (sandstone). These materials were seen at 90$110 \mathrm{~cm}$ in Trench 3, 34-97 cm in Trench 4, 24$110 \mathrm{~cm}$ in Trench 5, and 32-110 $\mathrm{cm}$ in Trench 6 . These materials included a lens of burned rock fragments located at ca. 75-90 cm deep and one possible feature. The feature was located in
Trench 4 and consisted of a dense accumulation of mussel shells approximately $20 \mathrm{~cm}$ long and $8 \mathrm{~cm}$ thick. Other areas along the trench walls contained burned rock fragment clusters, but no distinct feature patterning was determined. Charcoal flecks and smears were common throughout each trench containing cultural material. Four shovel tests were placed adjacent to trenches containing cultural materials. Cultural materials were present in all four shovel tests between 30 and $100 \mathrm{~cm}$ and consisted of small burned rock fragments and mussel shell fragments.

Based on its context in aggrading Holocene alluvium, the presence of intact features, and the presence of datable charcoal, it appears that 41DM151 may contain important archeological information. It is recommended that the site be tested to determine its age and contents and better assess its eligibility for listing in the National Register of Historic Places and designation as a State Archeological Landmark.

\section{Work Authorization 33: 41UV444}

Site 41UV444 was recorded by Al McGraw of TxDOT in October 2004. It is located on the north side of State Highway 127 and is a small upland burned rock midden. The midden was first exposed during excavation of an SBC utility line trench and identified by a TxDOT inspector, who reported it to ENV. McGraw then visited the site and conducted preliminary recording. He noted that the site is ca. $14 \mathrm{~m}$ long within the existing right of way and that most of it is on private property to the north. He observed the midden, which is composed of dark organic sediment encompassing burned limestone rocks of various sizes, just below the ground surface. No diagnostic artifacts were encountered during the initial recording.

Personnel with Prewitt and Associates returned to do additional recording under Work Authorization 33. The work consisted of visual inspection of the area around the site accompanied by the excavation of 3 trenches and 12 shovel tests. Trench 1 was placed ca. $1 \mathrm{~m}$ south of the original SBC utility trench. This trench exposed the largest section of the midden within the right of way. The trench was $22 \mathrm{~m}$ long and revealed a ca. 14.5-m-long section of the midden. Due to shallow bedrock and large aggregations 
of caliche, the midden was located at varying depths throughout the trench. In the central portion, the midden reached a depth of ca. $50 \mathrm{~cm}$; at the edges, it extended down to ca. $20 \mathrm{~cm}$ An abandoned phone cable was encountered at the west end of the trench. The cable appeared to be running primarily south of Trench 1. Trenches 2 and 3 were placed ca. $3 \mathrm{~m}$ south of Trench 1 . Both of these trenches were ca. $10 \mathrm{~m}$ long and ranged between 25 and $50 \mathrm{~cm}$ deep. Located ca. $2 \mathrm{~m}$ north of State Highway 127 , these trenches revealed only thin midden deposits at ca. $25 \mathrm{~cm}$ below the surface. Both trenches struck bedrock by $50 \mathrm{~cm}$. Shovel Tests 1-5 were placed east of the midden at intervals of $30 \mathrm{~m}$. These tests revealed shallow gravelly silty sand situated just above limestone bedrock. Shovel Tests 6-12 were excavated west of the midden, also at intervals of ca. $30 \mathrm{~m}$. These tests revealed gravelly silty clays and silty sands situated on top of bedrock. No cultural materials were encountered in any of the shovel tests.

Site $41 U V 444$ consists of a small upland burned rock midden measuring ca. $14 \mathrm{~m}$ eastwest. The north-south measurement is unknown at this time because the site is located on private property where a pronounced topographic rise is noticeable from the existing right of way. Visual inspection indicates that the central portion of the site is located ca. $4 \mathrm{~m}$ north of the edge of the right of way. At least three large depressions that appear to be looters' holes were observed near the central part of the site. The site lies beside a dry, ephemeral, upland drainage at the intersection of State Highway 127 and an unnamed road. The midden has a maximum thickness of ca. $50 \mathrm{~cm}$ in the central part of the feature and thins to the east, west, and south. The burned rock midden lies directly on an undulating weathered substrate of limestone and caliche, which shows no evidence of burning. Most of the upper portion of the midden in the existing right of way has been stripped away and capped with ca. $10 \mathrm{~cm}$ of fill. The coarsegrained midden matrix consists of burned, fractured, and broken angular pieces of limestone. The limestone clasts can be placed into three categories: tabular, cobbles, and angular. Most of the burned rocks are angular with sharp corners and edges, accounting for ca. 60-70 percent of the rocks. Tabular pieces and cobbles each account for ca. 15 percent. The rocks are typically gray in color with a few varying shades of white and red. The rocks range in size between 5 and $25 \mathrm{~cm}$. The fine-grained matrix consists of dense, sticky, organic silty clay, possibly colluvium originating from slopes within the immediate area. Artifacts are sparse, with observed items consisting of one ground stone mano and a few utilized flakes. No charcoal was encountered within the midden. Most of the deposits associated with the part of the site inside the existing right of way have been severely disturbed.

The part of 41UV444 that is within the existing right of way of State Highway 127 is too disturbed and too ephemeral to yield important information. Hence, it is not eligible for listing in the National Register of Historic Places or designation as a State Archeological Landmark.

\section{Work Authorization 35: 41AS27}

Previously recorded site 41AS27 was investigated during a survey for proposed widening of State Highway 35 in existing right of way on Lamar Peninsula. It was recorded originally by avocational archeologists George C. Martin and Wendell H. Potter in the late 1920s. Reportedly, it was a rich site on a large sand hill that rose $35 \mathrm{ft}$ above high tide. It had yielded many points, mostly arrow points, to local collectors over the years, and several human burials had been found there. According to their description (Martin n.d.:2), 41AS27 appears to have been a stratified oyster shell midden that was in danger of destruction by the imminent construction of State Highway 35 through it.

During the current survey, the existing right of way at the plotted location of 41AS27 was given close scrutiny. Numerous disturbances were noted there and on adjoining lands. A gas station lies on the southeast corner of the intersection of State Highway 35 and Park Road 13 followed by a retail shop. A 1.25-m-deep road cut begins just past the retail shop and continues $45 \mathrm{~m}$ to the south. This cut rises gently from 4 to $10 \mathrm{~m}$ beyond the roadbed and truncates an apparently natural rise that may contain the remnants of 41AS27. A slight ditch $2 \mathrm{~m}$ wide and $0.1 \mathrm{~m}$ deep runs between the road and the road cut. A historic marker lies at the south end of the road cut. The marker recognizes the historic town of Lamar. The right of way widens to ca. $82 \mathrm{~m}$ south of the historic marker, extending ca. $35 \mathrm{~m}$ beyond the roadbed into an open, grassy 
swath to the east followed by a low, dug-out wetland. This dug-out area also truncates the rise to the north where 41AS27 may lie. To the west of State Highway 35, thick vegetation beyond the ca. 10-m-wide cleared existing right of way obscures an old right of way edge and what appears to be the old State Highway 35 roadbed. The natural rise that extends out of the right of way east of the road does not extend west of the highway. Shell roads lead to water access on either side of the Copano Bay bridge.

Six shovel tests were excavated along the east right of way in search of any remains of 41AS27. Tests were dug on the west edge of the truncated rise immediately east of the road cut. Shovel Tests 1, 2, and 4 were placed in line with the historic marker at the edge of the right of way. Shovel Test 3 was placed 2 m west of the edge of the right of way, slightly downslope along the road cut. Shovel Test 1 was $40 \mathrm{~m}$ north of the historic marker. Shovel Tests 2 and 3 were placed at $10-\mathrm{m}$ intervals to the south of Shovel Test 1, and Shovel Test 4 was placed $4 \mathrm{~m}$ north of the marker. Shovel Tests 5 and 6 were placed in a low area off the rise 10 and $20 \mathrm{~m}$ south of the historic marker where the right of way widens.

Shovel Tests 1-4 reached $100 \mathrm{~cm}$ deep and exposed $45-80 \mathrm{~cm}$ of grayish brown sand followed by finer-grained pale brown sand. Shovel Test 1 encountered a lens of primarily complete oyster shells from 0 to $60 \mathrm{~cm}$ with two small pieces of asphalt and one piece of glass in the upper $20 \mathrm{~cm}$. Shovel Test 2 exposed the shell lens, with many whole oyster shells, at 14$50 \mathrm{~cm}$; a larger piece of asphalt was found at $35 \mathrm{~cm}$. Shovel Test 3 , which was placed slightly off the top of the rise, exposed one fragment of an unidentified animal long bone in the upper $20 \mathrm{~cm}$ and scattered broken shells and shell bits throughout, but no discrete shell lens was encountered. Shovel Test 4 exposed the oyster shell lens at $0-45 \mathrm{~cm}$ with less concentrated shell fragments below. Two partial gastropod columellae were recovered at $20-40 \mathrm{~cm}$, and two more were found at 40-60 cm. Shovel Tests 5 and 6, placed in a low area off the rise, were dug only to $10 \mathrm{~cm}$ and exposed $5 \mathrm{~cm}$ of humic dark gray clay over $5 \mathrm{~cm}$ of very wet pale brown clay. Two oyster shell pieces were encountered in Shovel Test 5; no shells were found in Shovel Test 6.

The oyster shells found in Shovel Tests 1-4 probably are prehistoric deposits associated with 41AS27. Though no lithic or ceramic artifacts were found to demonstrate this conclusively, oyster shells are a common constituent of prehistoric shell middens in the area, and the single bone fragment and four gastropod columellae fragments suggest a prehistoric origin rather than a purely modern one from, for example, introduction of shells as road base or dredged materials. The glass recovered in Shovel Test 1 and the asphalt recovered in Shovel Tests 1 and 2 do indicate some disturbance, though. The asphalt is clearly modern, based on the fact that it has sand, shell hash, and gravel inclusions, and thus it is not asphaltum, which occurs commonly in prehistoric shell middens. This modern disturbance could have been associated with the construction or maintenance of State Highway 35, construction of the large billboard on top of the rise just east of the right of way, other historic use of the rise (e.g., during occupation of the town of Lamar), or even dredging of the low wetlands east of the right of way and south of the historic marker.

In any case, assuming that the rise does contain a remnant of $41 \mathrm{AS} 27$, it is clear that almost all of the most-intact part of the site is outside the State Highway 35 right of way. What appears to be reasonably intact shell midden was found only in Shovel Tests 1, 2, and 4 at the very edge of the right of way. The portion of the rise between these tests and the road has been beveled off, with Shovel Test 3 just $2 \mathrm{~m}$ from the right of way edge containing only scattered shells and no intact midden. Hence, the part of 41AS27 within the State Highway 35 right of way does not have the capacity to contribute important information and is ineligible for listing in the National Register of Historic Places or designation as a State Archeological Landmark.

\section{Patterns in Site Distributions}

With a sample of just 25 prehistoric sites and 1 historic site (at only 17 of which archeological materials actually were observed), it is difficult to draw conclusions about patterns in site distributions and associations between site locations and elements of the environment. Nonetheless, it is useful to note the 26 sites occupy both upland and lowland topographic settings. Most of the sites are in the Laredo District $(n=21), 4$ are in the Corpus Christi District, 
and 1 is in the San Antonio District. No sites were investigated in the Pharr District.

The Laredo District sites include both upland settings (41DM3, 41DM4, 41KY28, 41KY51, 41LS98, 41MV57, 41MV58, 41WB17, 41WB18, 41WB214, 41WB456, 41WB457, 41WB619, 41WB620, and 41ZV344) and Holocene alluvial settings (41DM49, 41DM150, 41DM151, 41KY13, 41VV1961, and 41VV1963). The upland sites are restricted to the surface, or nearly so, and half of the alluvial sites are in thin Holocene deposits. Only 41DM151, perhaps 41DM49, and 41VV1961 are in thick Holocene alluvium. Three of the Corpus Christi District sites are in upland settings (41AS27, $41 \mathrm{LK} 11$, and 41NU254), and one (41SP99) is in thin Holocene alluvium. The one site in the San Antonio District (41UV444) is in an upland setting.

\section{Utility of Existing Methods}

The methods employed for Impact Evaluations and Surveys are consistent with a reasonable and good-faith effort to comply with federal and state laws governing identification of archeological sites that are eligible for listing in the National Register of Historic Places or designation as State Archeological Landmarks. The level of effort typically required to complete an Impact Evaluation (e.g., 1-2 hours for a single bridge replacement) is appropriate given the intent of this type of work and the generally small project areas. When Impact Evaluations can quickly separate those project areas where survey is truly a good idea from those where sites are very unlikely or almost surely disturbed, they are an efficient and relatively inexpensive measure to guard against the loss of important archeological data.

The levels of effort spent on Surveys and the amounts of work done (i.e., numbers of trenches and shovel tests) also are appropriate given the sizes of the project areas, although the amount of work can vary based on factors other than project size (e.g., backhoe accessibility, depth to ground water, landowner permission to trench, extent of disturbance, and number and location of buried utilities that must be avoided during trenching). The work done on these surveys easily meets or exceeds the Texas Historical Commission's archeological survey standards, except in some cases in which only trenches were dug. This was the case in some floodplain settings where shovel testing was considered ineffective and inefficient because of the thickness of the alluvium or because of dense clay soils. In these cases, the much greater subsurface visibility afforded by the backhoe trenches and the fact that the number of trenches well exceeds the minimum required compensates for the lack of shovel testing.

\section{EVALUATION OF THE NEED FOR SURVEY}

This final section deals with the related topics of identifying patterns of existing conditions that affect the need for survey and predicting when field inspections are and are not needed. Based on the work done during this project, these issues can be addressed by looking at how often survey was deemed warranted when an Impact Evaluation was completed and the factors that contributed to these evaluations, as well as how often potentially significant archeological sites were found during surveys.

Of the 53 Impact Evaluations done, 3 led to recommendations that survey was needed before construction. On 2 of these 3, new right of way was likely necessary, but the details of where and how much it would be were unknown when the Impact Evaluations were done. Because both were in settings with the potential for thick Holocene alluvium and buried sites, survey was considered warranted. The third project area involved no new right of way, but survey was recommended because a prehistoric site found during the Impact Evaluation was considered to have the potential to extend into an area where buried remains could be present within the existing right of way.

The other 50 Impact Evaluations resulted in recommendations that no survey be required before construction based on the limited potential for sites with good integrity. Survey was not warranted for a variety of reasons. First, 39 of these Transportation Activities will require no new rights of way or easements, with all construction-related disturbances restricted to existing, already-disturbed rights of way. Second, 6 cases involved bridge replacements on small county roads where disturbance was extensive, and, though it was unknown if new right of way would be needed, this was considered unlikely. The other 5 Transportation Activities required 
new right of way ranging from 0.1 to 26.2 acres. On 3 of these, disturbance was extensive enough to preclude the possibility of archeological sites in good context. On 1, surface and subsurface visibility was good enough to show that archeological sites were not present. And in the final case, the Transportation Activity was restricted to a disturbed upland landform where intact archeological sites were considered unlikely.

The results of this project are consistent with the traditional thought that Transportation Activities that do not involve new right of way, particularly when they are in uplands or areas with thin Holocene deposits, are likely to be poor candidates for productive archeological survey. Beyond this, the frequent inability to predetermine where significant existing disturbances and thin (or no) alluvium might exist in project areas suggests that Impact Evaluations will continue to be the prudent choice on certain kinds of Transportation Activities, particularly those where significant accumulations of Holocene sediments could be present and those that are in settings (e.g., valley margins or proximity to known sites) where sites are likely, whether new right of way is involved or not.

Of the 35 Surveys done under this contract, 13 investigated a total of 3 newly recorded and 12 previously recorded sites; all 15 sites are prehistoric (these figures exclude previously recorded sites that could not be re-located or where no archeological remains were observed). This rate of positive surveys (37 percent) is lower than the results of two previous Survey and Impact Evaluation projects done for TxDOT by Prewitt and Associates (42 percent in the Atlanta, Dallas, Fort Worth, Paris, and Waco Districts; 45 percent in the Austin and Waco Districts) and higher than for two others (16 percent in the Bryan, Corpus Christi, San Antonio, and Yoakum Districts; 25 percent in the Abilene, Austin, Brownwood, Bryan, Fort Worth, Waco, and Yoakum Districts). The reasons for the disparate rates of positive surveys are not apparent, although they do not appear to relate to differences in the amount of work done in completing surveys. For example, 96 trenches and 306 shovel tests were dug during the 35 surveys reported here, for an average of 2.7 trenches and 8.7 shovel tests per survey. This compares favorably to 5.9 trenches and 1.7 shovel tests per survey in the Austin and Waco Districts; 3.9 trenches and 4.2 shovel tests per survey in the
Bryan, Corpus Christi, San Antonio, and Yoakum Districts; 6.0 trenches and 5.4 shovel tests per survey in the Atlanta, Dallas, Fort Worth, Paris, and Waco Districts; and 4.5 trenches and 3.3 shovel tests in the Abilene, Austin, Brownwood, Bryan, Fort Worth, Waco, and Yoakum Districts. In any case, the rate of positive surveys in the current project is sufficient to suggest that conducting surveys in these areas generally was a good idea.

Of the 15 sites actually investigated during surveys (excludes 4 previously recorded sites that could not be re-located or where no archeological remains were observed), 1 was recommended for testing to assess its eligibility for listing in the National Register of Historic Places and designation as a State Archeological Landmark. This site, 41DM151, was judged to have the potential for important information because it contains apparently stratified cultural deposits in aggrading Holocene alluvium along the Nueces River. Hence, it is possible that discrete components may be present and isolable. In addition, 41VV1961 was intensively surveyed and judged to be eligible for National Register listing State Archeological Landmark designation. Site 41VV1961 was considered significant because it appeared to have stratified, 150-cm-thick cultural deposits where discrete components could be isolable.

Of the 13 sites (or parts of sites) investigated during surveys and not considered to warrant further work, 8 prehistoric sites (41AS27, 41KY28, 41LK11, 41LS98, 41UV444, 41WB619, $41 \mathrm{WB} 620$, and 41ZV344) are in upland settings where Holocene sediments are usually thin or absent altogether; these have suffered from varying amounts of disturbance, with some having no intact deposits at all in areas that the Transportation Activities will affect. Because components could not be isolated or because of disturbance, these sites lack the capacity to contribute important information. Five sites are in Holocene alluvial settings. In four cases (41DM150, 41KY13, 41SP99, and 41VV1963), the Holocene deposits are thin, though, and this, usually combined with disturbance, makes isolating components problematical, limiting the capacity of the sites to yield important information. The fifth site (41DM49) may have thicker alluvium, but almost all of the site in the current project area has been destroyed.

In total, 13 percent of the sites investigated 
during these surveys were considered to have, or to have the potential for, important information. It can be argued that this percentage should be higher, if the point is to maximize the effectiveness of the dollars spent on surveys. That is, shouldn't we be finding higher percentages of significant sites? The answer to this question is not simple, however. There are many variables that contribute to decisions about when surveys are needed, and all sites encountered during surveys must be recorded, regard- less of their apparent significance. There is even a competing argument that the percentage should go down as we get better at discriminating sites that are truly important from ones that are not. Ultimately, simple expectations such as these probably will never, or seldom, be met because the need to make sure that public monies are used effectively must be balanced against the need to ensure that important cultural resources are not lost without receiving the proper treatment. 



\section{REFERENCES CITED}

Alexander, Robert K.

1970 Archeological Investigations at Parida Cave, Val Verde County, Texas. Papers of the Texas Archeological Salvage Project 19. The University of Texas at Austin.

Aten, Lawrence E.

1983 Indians of the Upper Texas Coast. Academic Press, New York.

Bement, Leland C.

1986 Excavation of the Late Pleistocene Deposits of Bonfire Shelter, Val Verde County, Texas. Archeology Series 1. Texas Archeological Survey, The University of Texas at Austin.

1989 Lower Pecos Canyonlands. In From the Gulf to the Rio Grande: Human Adaptation in Central, South, and Lower Pecos Texas, by Thomas R. Hester, Stephen L. Black, D. Gentry Steele, Ben W. Olive, Anne A. Fox, Karl J. Reinhard, and Leland C. Bement, pp. 63-76. Research Series No. 33, Arkansas Archeological Survey, Fayetteville.

Birmingham, William W., and Thomas R. Hester 1976 Late Pleistocene Archaeological Remains from the Johnson-Heller Site, Texas Coastal Plain. In Papers on Paleo-Indian Archeology in Texas: 1, pp. 15-33. Special Report No. 3. Center for Archaeological Research, The University of Texas at San Antonio.

Black, Stephen L.

1986 The Clemente and Herminia Hinojosa Site, 41JW8: A Toyah Horizon Campsite in Southern Texas. Special Report No. 18. Center for Archaeological Research, The University of Texas at San Antonio. 1989a South Texas Plains. In From the Gulf to the Rio Grande: Human Adaptation in Central, South, and Lower Pecos Texas, by Thomas R. Hester, Stephen L. Black, D. Gentry Steele, Ben W. Olive, Anne A. Fox, Karl J. Reinhard, and Leland C. Bement, pp. 39-62. Research Series No. 33. Arkansas Archeological Survey, Fayetteville.

1989b Central Texas Plateau Prairie. In From the Gulf to the Rio Grande: Human Adaptation in Central, South, and Lower Pecos, Texas, by Thomas R. Hester, Stephen L. Black, D. Gentry Steele, Ben W. Olive, Anne A. Fox, Karl J. Reinhard, and Leland C. Bement, pp. 17-38. Research Series No. 33. Arkansas Archeological Survey, Fayetteville.

Black, Stephen L., and I. Waynne Cox

1983 A Cultural Resource Survey of Dredge Disposal Sites Along the Gulf Intracoastal Waterway, Brazoria and Matagorda Counties, Texas. Archaeological Survey Report No. 124. Center for Archaeological Research, The University of Texas at San Antonio.

Black, Stephen L., Linda W. Ellis, Darrell G. Creel, and Glenn T. Goode

1997 Hot Rock Cooking on the Greater Edwards Plateau: Four Burned Rock Midden Sites in West Central Texas, Volumes 1 and 2. Studies in Archeology 22. Texas Archeological Research Laboratory, The University of Texas at Austin. Archeology Studies Program, Report 2. Environmental Affairs Department, Texas Department of Transportation, Austin.

Black, Stephen L., and A. Joachim McGraw 1985 The Panther Springs Creek Site: Cultural 
Change and Continuity within the Upper Salado Creek Watershed, South-Central Texas. Archeological Survey Report No. 100. Center for Archaeological Research, The University of Texas at San Antonio.

Bolton, Herbert E.

1970 Texas in the Middle Eighteenth Century: Studies in Spanish Colonial History and Administration. The Texas State Historical Association and the University of Texas Press, Austin.

Bousman, C. Britt

1998 Paleoenvironmental Change in Central Texas: The Palynological Evidence. Plains Anthropologist 43(164):201-219.

Brown, David O.

1983 The Berger Bluff Site (41GD30A): Excavations in the Upper Deposits, 1979. Archaeological Survey Report No. 115. Center for Archaeological Research, The University of Texas at San Antonio.

Brown, Kenneth M.

1991 Prehistoric Economics of Baker Cave: A Plan for Research. In Papers on the Lower Pecos Prehistory, edited by S. A. Turpin, pp. 87-140. Studies in Archeology 8. Texas Archeological Research Laboratory, The University of Texas at Austin.

1996 Berger Bluff. In The New Handbook of Texas, Vol. 1:497-498. The Texas State Historical Association, Austin.

Brown, Kenneth M., Daniel R. Potter, Grant D. Hall, and Stephen L. Black

1982 Excavations at 41LK67, a Prehistoric Site in the Choke Canyon Reservoir, South Texas. Choke Canyon Series 7. Center for Archaeological Research, The University of Texas at San Antonio.

Bruseth, Jim, and Jeff Durst

2002 The Story of the First Presidio La Bahia Slowly Emerges. Current Archeology in Texas, Volume 4, No. 2, pp. 1-3. Texas Historical Commission, Austin.

Bureau of Economic Geology

1974 Geologic Atlas of Texas, San Antonio Sheet. Bureau of Economic Geology, The University of Texas at Austin.

1975 Geologic Atlas of Texas, Corpus Christi Sheet. Bureau of Economic Geology, The University of Texas at Austin. 1976a Geologic Atlas of Texas, Crystal CityEagle Pass Sheet. Bureau of Economic Geology, The University of Texas at Austin.

1976b Geologic Atlas of Texas, Laredo Sheet. Bureau of Economic Geology, The University of Texas at Austin.

1976c Geologic Atlas of Texas, McAllenBrownsville Sheet. Bureau of Economic Geology, The University of Texas at Austin.

1977 Geologic Atlas of Texas, Del Rio Sheet. Bureau of Economic Geology, The University of Texas at Austin.

1981 Geologic Atlas of Texas, Llano Sheet. Bureau of Economic Geology, The University of Texas at Austin.

1987 Geologic Atlas of Texas, Beeville-Bay City Sheet. Bureau of Economic Geology, The University of Texas at Austin.

Calhoun, Cecil A.

1999 Majolica and Faience from the Presidio Loreto Site (41VT8). Bulletin of the Texas Archeological Society 70:339354.

Campbell, Thomas N.

1947 The Johnson Site: The Type Site of the Aransas Focus of the Texas Coast. Bulle tin of the Texas Archeological and Paleontological Society 18:40-75.

1952 The Kent-Crane Site: A Shell Midden on the Texas Coast. Bulletin of the Texas Archeological and Paleontological Society 23:39-77.

1958 Archeology of the Central Southern Sections of the Texas Coast. Bulletin of the Texas Archeological Society. 27:7-46.

1976 Archaeological Investigations at the Morhiss Site, Victoria County, Texas, 1932-1940. In An Archaeological Survey of Coleto Creek, Victoria and Goliad Counties, Texas, by Anne A. Fox and Thomas R. Hester, pp. 81-85. Archaeological Survey Report No. 18. Center for Archaeological Research, The University of Texas at San Antonio.

1983 The Coahuiltecans and Their Neighbors. In Handbook of North American Indians 
10:343-358. Smithsonian Institution, Washington, D. C.

1988 Indians of Southern Texas and Northeastern Mexico: Selected Writings of Thomas Nolan Campbell. Texas Archeological Research Laboratory, with the cooperation of the Department of Anthropology, the College of Liberal Arts, and the Institute of Latin American Studies, The University of Texas at Austin.

Campbell, T. N., and T. J. Campbell

1981 Historic Indian Groups of the Choke Canyon Reservoir and Surrounding Area, Southern Texas. Choke Canyon Series 1. Center for Archaeological Research, The University of Texas at San Antonio.

Carpenter, Steve, Ken Lawrence, and Kirk French 2002 An Archeological Survey of High Probability Areas along the US 277 Right-of-Way from Sycamore Creek to San Felipe Creek near Del Rio, Val Verde County, Texas. Archeological survey report submitted to the Texas Department of Transportation, Austin. SWCA Environmental Consultants, Inc., Austin.

Castañeda, Carlos E.

1936- Our Catholic Heritage in Texas, 151919561936.7 vols. Von Boeckmann-Jones Co., Austin.

Chadderdon, Mary F.

1983 Baker Cave, Val Verde County, Texas: The 1976 Excavations. Special Report 13. Center for Archeological Research, The University of Texas at San Antonio.

Collins, Michael B.

1968 A Note on Broad Corner-Notched Projectile Points Used in Bison Hunting in Western Texas. The Bull Roarer 3(2):13-14. The University of Texas Anthropological Society, Department of Anthropology, The University of Texas at Austin.

1990 The Archaeological Sequence at Kincaid Rockshelter, Uvalde County, Texas. Transactions of the Twenty-Fifth Regional Archeological Symposium for Southeastern New Mexico and Western Texas, pp. 2534.

1995 Forty Years of Archeology in Central Texas. Bulletin of the Texas Archeological Society 66:361-400.

1998 Early Paleoindian Components. In Wilson-
Leonard: An 11,000-Year Archeological Record of Hunter-Gatherers in Central Texas, Volume I, edited and assembled by Michael B. Collins, pp. 123-159. Studies in Archeology 31. Texas Archeological Research Laboratory, The University of Texas at Austin. Archeology Studies Program, Report 10. Environmental Affairs Division, Texas Department of Transportation.

Collins, Michael B., Bruce Ellis, and Cathy Dodt-Ellis 1990 Excavations at the Camp Pearl Wheat Site (41KR243): An Early Archaic Campsite on Town Creek, Kerr County, Texas. Studies in Archeology 6. Texas Archeological Research Laboratory, The University of Texas at Austin.

Collins, M. B., G. L. Evans, T. N. Campbell, M. C. Winans, and C. E. Mear

1989 Clovis Occupation at Kincaid Rockshelter, Texas. Current Research in the Pleistocene $6: 3-4$.

Collins, Michael B., Jan Guy, and Susan W. Dial

1998 The Archaic Period, 8800 to 1300 B.P.. In Wilson-Leonard: An 11,000-Year Archeological Record of Hunter-Gatherers in Central Texas, Volume I, edited and assembled by Michael B. Collins, pp. 211-270. Studies in Archeology 31. Texas Archeological Research Laboratory, The University of Texas at Austin. Archeology Studies Program, Report 10. Environmental Affairs Division, Texas Department of Transportation.

Collins, M. B., T. R. Hester, and P. J. Hedrick

1992 Engraved Cobbles from the Gault Site, Central Texas. Current Research in the Pleistocene 9:3-4.

Corbin, James E.

1974 A Model for Cultural Succession for the Coastal Bend Area of Texas. Bulletin of the Texas Archeological Society 45:2954.

1976 The Archaic of the Texas Coast. In The Texas Archaic: A Symposium, edited by Thomas R. Hester, pp. 91-97. Special Report No. 2. Center for Archaeological Research, The University of Texas at San Antonio.

Cox, Kim A., and Herman A. Smith

1988 Kent Crane Revisited. La Tierra 15(3):2428. 
Davis, Mike, and Jim Bruseth

2000 The Fort St. Louis Archeological Project, October 1999 through Mid-February 2000. Current Archeology in Texas 2(1):1-4.

2001 Recent Archeological and Architectural Discoveries at Fort St. Louis. Current Archeology in Texas 3(1):6-7. Texas Historical Commission, Austin.

Davis, Mike, Jeff Durst, Curtis Tunnell, and Jim Bruseth

2000 The Fort St. Louis Archeological Project: An Update on Recent Discoveries. Current Archeology in Texas 1(2)1-4. Texas Historical Commission, Austin.

Dering, Phil

1999 Earth-Oven Plant Processing in Archaic Period Economies: An Example from a Semi-arid Savannah in South-Central North America. American Antiquity 64(4):659-674.

Diamond, David D., David H. Riskind, and Steve L. Orzell

1987 A Framework for Plant Communities Classification and Conservation in Texas. Texas Journal of Science 39(3):203-221.

Dibble, David S., and Dessamae Lorrain

1968 Bonfire Shelter: A Stratified Bison Kill Site, Val Verde County, Texas. Miscellaneous Papers No. 1. Texas Memorial Museum, The University of Texas at Austin.

Dibble, David S.

1965 Bonfire Shelter:A Stratified Bison Kill Site in the Amistad Reservoir Area, Val Verde County, Texas. Miscellaneous Papers 3. Texas Archeological Salvage Project, The University of Texas at Austin.

1967 Excavations at Arenosa Shelter, 1965-66. Report submitted to the National Park Service by the Texas Archeological Salvage Project, The University of Texas at Austin.

Epstein, Jeremiah F.

1960 Centipede and Damp Caves. Excavations in Val Verde County, Texas, 1958. Report submitted to the National Park Service by theTexas Archeological Salvage Project, The University of Texas at Austin.

1963 Centipede and Damp Caves. Excavations in Val Verde County, Texas, 1958. Bulletin of the Texas Archeological Society $33: 1-129$.

1969 The San Isidro Site, An Early Man Campsite in Nuevo Leon, Mexico. Anthropology Series 7. Department of Anthropology, The University of Texas at Austin.

Fenneman, Nevin M.

1931 Physiography of Western United States. McGraw-Hill Book Company, Inc., New York.

1938 Physiography of Eastern United States. McGraw-Hill Book Company, Inc., New York.

Fields, Ross C., Karl W. Kibler, Eloise F. Gadus, and Amy M. Holmes

2002 Archeological Impact Evaluations and Surveys in the Texas Department of Transportation's Bryan, Corpus Christi, San Antonio, and Yoakum Districts, 2000-2001. Archeological Studies Program, Report 35. Texas Department of Trans-portation, Environmental Affairs Divi-sion, Austin. Reports of Investigations No. 133. Prewitt and Associates, Inc., Austin.

Fox, Anne A., and Thomas R. Hester

1976 Archaeological Survey of Coleto Creek, Victoria and Goliad Counties, Texas. Archaeological Survey Report No. 18. Center for Archaeological Research, The University of Texas at San Antonio.

Fox, Anne A., Stephen L. Black, and Steven R. James 1979 Intensive Survey and Testing of Archaeological Sites on Coleto Creek, Victoria and Goliad Counties, Texas. Archaeological Survey Report No. 67. Center for Archaeological Research, The University of Texas at San Antonio.

Fox, Daniel E.

1979 The Lithic Artifacts of Indians at the Spanish Colonial Missions, San Antonio, Texas. Special Report No. 8. Center for Archaeological Research, The University of Texas at San Antonio.

Fox, Daniel E., and Hayden Whitsett

1979 An Archeological Reconnaissance of the Laredo Water Quality Enhancement Project, Webb County, Texas. Letter report enclosed in letter of December 6, 1979, from E. Long to A. A. Perez. 
Fritz, Gayle

1975 Matagorda Bay Area, Texas: A Survey of the Archaeological and Historical Resources. Research Report No. 45. Texas Archeological Survey, The University of Texas at Austin.

Gadus, Eloise F., Marie E. Blake, Martha Doty Freeman, and Karl Kibler

1999 National Register Testing of Prehistoric and Historic Sites and Survey of Placement Areas, Channel to Victoria, Calhoun and Victoria Counties, Texas. Reports of Investigations No. 121. Prewitt and Associates, Inc., Austin.

Gephard, D.

1960 Prehistoric Paintings of the Diablo Region of Western Texas. Publications in Art and Science 3. Roswell Museum and Art Center, Roswell, New Mexico.

1965 Prehistoric Rock Paintings of the Seminole Canyon Area, Val Verde County, Texas. Report to the National Park Service, University of California at Santa Barbara.

Gilmore, Kathleen Kirk

1996a San Francisco Xavier de Horcasitas Mission. In The New Handbook of Texas, Vol. 5:849. The Texas State Historical Association, Austin.

1996b San Ildefonso Mission. In The New Handbook of Texas, Vol. 5:853-854. The Texas State Historical Association, Austin.

Goode, Glenn T.

1991 Late Prehistoric Burned Rock Middens in Central Texas. In The Burned Rock Middens of Texas: An Archeological Symposium, edited by Thomas R. Hester, pp. 71-93. Studies in Archeology 13. Texas Archeological Research Laboratory, The University of Texas at Austin.

Graham, J. A., and W. B. Davis

1958 Appraisal of the Archeological Resources of Diablo Reservoir, Val Verde County, Texas. Report to the National Park Service by the Inter-Agency Archeological Salvage Program, Field Office, Austin, Texas.

Grieder, Terence

1965 Report on a Study of the Pictographs in Satan Canyon, Val Verde Canyon,Texas. Miscellaneous Papers 2. Texas Archeologi- cal Salvage Project, The University of Texas at Austin.

Griffen, W. B.

1969 Cultural Change and Shifting Populations in Central Northern Mexico. Anthropological Papers of the University of Arizona 13. University of Arizona Press, Tuscon.

Hall, Grant D.

1981 Allens Creek: A Study in the Cultural Prehistory of the Brazos River Valley, Texas. Research Report No. 61. Texas Archeological Survey, The University of Texas at Austin.

1995a A Perspective on Some Prehistoric Cemeteries in Texas: Loma Sandia in the Regional Setting. In Archeological Investigations at the Loma Sandia Site (41LK28): A Prehistoric Cemetery and Campsite in Live Oak County, Texas, by Anna Jean Taylor and Cheryl Lynn Highley, Vol. 1, pp. 47-56. Studies in Archeology 20. Texas Archeological Research Laboratory, The University of Texas at Austin.

1995b Prehistoric Cemeteries on the Texas Central Coastal Plain: Interpretations and Hypotheses. In Archeological Investigations at the Loma Sandia Site (41LK28): A Prehistoric Cemetery and Campsite in Live Oak County, Texas, by Anna Jean Taylor and Cheryl Lynn Highley, Vol. 2, pp. 633-647. Studies in Archeology 20. Texas Archeological Research Laboratory, The University of Texas at Austin.

Hall, Grant D., Stephen L. Black, and Carol Graves 1982 Archaeological Investigations at Choke Canyon Reservoir, South Texas: The Phase I Findings. Choke Canyon Series 5. Center for Archaeological Research, The University of Texas at San Antonio.

Hall, Grant D., Thomas R. Hester, and Stephen L. Black

1986 The Prehistoric Sites at Choke Canyon Reservoir, South Texas: Results of Phase II Archaeological Investigations. Choke Canyon Series 10. Center for Archaeological Research, The University of Texas at San Antonio.

Henderson, Jerry, and Glenn T. Goode

1991 Pavo Real: An Early Paleoindian Site in South-Central Texas. Current Research in the Pleistocene 8:26-28. 
Hester, Thomas R.

1976 Late Pleistocene Aboriginal Adaptations in Texas. In Papers on Paleo-Indian Archaeology in Texas: I, pp. 1-10. Special Report No. 3. Center for Archaeological Research. The University of Texas at San Antonio.

1980 A Survey of Paleo-Indian Remains Along the Texas Coast. In Papers on the Archaeology of the Texas Coast, edited by L. Highley and T. R. Hester, pp. 1-22. Special Report 11. Center for Archaeological Research, The University of Texas at San Antonio.

1983 Late Paleoindian Occupations at Baker Cave, Southwestern Texas. Bulletin of the Texas Archeological Society 53:101120.

1989 Historic Native American Populations. In From the Gulf to the Rio Grande: Human Adaptation in Central, South, and Lower Pecos, Texas, by Thomas R. Hester, Stephen L. Black, D. Gentry Steele, Ben W. Olive, Anne A. Fox, Karl J. Reinhard, and Leland C. Bement, pp. 7784. Research Series No. 33. Arkansas Archeological Survey, Fayetteville.

1995 The Prehistory of South Texas. Bulletin of the Texas Archeological Society 66:427459.

1999 Artifacts, Archeology, and Cabeza de Vaca in Southern Texas and Northeastern Mexico. Bulletin of the Texas Archeological Society 70:17-28.

Highley, Cheryl Lynn

1986 Archaeological Investigations at 41LK201, Choke Canyon Reservoir, Southern Texas. Choke Canyon Series 11. Center for Archaeological Research, The University of Texas at San Antonio.

Hindes, V. Kay, Anne A. Fox, and E. H. Schmiedlin 1999 An Overview of Test Excavations and Documentary Research at 41VT10, the Tonkawa Bank Site, Victoria City Park, Victoria Texas. Bulletin of the Texas Archeological Society 70:79-96.

Houk, Brett A., and Thanet Skoglund

2003 An Archeological Survey of Box Canyon Road, Val Verde County, Texas. Archeological survey report submitted to the Texas Department of Transportation, Austin.
SWCA Environmental Consultants, Inc., Austin.

Houk, B. A., S. Tomka, B. Bousman, C. K. Chandler, B. Moses, M. Renner, and M. Lyons

1997 The Greenbelt Core: A Polyhedral Blade Core from San Antonio, Texas. Current Research in the Pleistocene 14:104-106.

Houk, Brett A., and Steve Carpenter

2004 Archeological Impact Evaluations and Surveys in the Texas Department of Transportation's Corpus Christi, Laredo, Pharr, and San Antonio Districts, 20012003. Archeological Studies Program Report 58. Texas Department of Transportation, Environmental Affairs Division, Austin. SWCA Cultural Resource Report No. 03-308, SWCA Environmental Consultants, Inc., Austin.

Huebner, Jefferey A.

1988 The Archaeology of Blue Bayou: A Late Prehistoric and Archaic Mortuary Site, Victoria County, Texas. M.A. thesis, Department of Anthropology, The University of Texas at San Antonio.

1991 Late Prehistoric Bison Populations in Central and South Texas. Plains Anthropologist 36(137):343-358.

Jackson, A. T.

1938 Picture-Writing of Texas Indians. Anthropological Papers. Bureau of Research in the Social Sciences Study 27. The University of Texas at Austin.

Jantz, Lee Meadows, Richard L. Jantz, Nicholas P. Herrmann, Corey S. Sparks, Katherine E. Weisensee, and Derinna V. Kopp

2002 Archaeological Investigations at the Last Spanish Colonial Mission Established on the Texas Frontier: Nuestra Senora del Refugio (41RF1), Refugio County, Texas, Volume II, Osteological Analysis. Archaeological Survey Report No. 315. Center for Archaeological Research, The University of Texas at San Antonio. Archeological Studies Program, Report 39. Texas Department of Transportation, Environmental Affairs Division, Austin.

Jelks, Edward B.

1962 The Kyle Site: A Stratified Central Texas Aspect Site in Hill County, Texas. Archaeology Series No. 5. Department of Anthropology, The University of Texas at Austin. 
Johnson, LeRoy Jr.

1964 The Devil's Mouth Site:A Stratified Campsite at Amistad Reservoir, Val Verde County, Texas. Archeology Series 6. Department of Anthropology, The University of Texas at Austin.

1994 The Life and Times of Toyah-Culture Folk As Seen from the Buckhollow Encampment, Site 41KM16, of Kimble County, Texas. Office of the State Archeologist Report 38. Texas Department of Transportation and Texas Historical Commission, Austin.

1995 Past Cultures and Climates at Jonas Terrace: $41 M E 29$ of Medina County, Texas. Office of the State Archeologist Report No. 40. Texas Department of Transportation and Texas Historical Commission, Austin.

Johnson, LeRoy Jr., and Glenn T. Goode

1994 A New Try at Dating and Characterizing Holocene Climates, as Well as Archeological Periods, on the Eastern Edwards Plateau. Bulletin of the Texas Archeological Society 65:1-51.

Johnson, LeRoy Jr., and Thomas N. Campbell 1991 Sanan: Traces of a Previously Unknown Aboriginal Language in Colonial Coahuila and Texas. Plains Anthropologist 37 (140):185-212.

Johnson, LeRoy Jr., Dee Ann Suhm, and Curtis D. Tunnell

1962 Salvage Archeology of Canyon Reservoir: The Wunderlich, Footbridge, and Oblate Sites. Bulletin No. 5. Texas Memorial Museum, The University of Texas at Austin.

Katz, Paul R.

1987 Archaeological Mitigation at 41BX300,

Salado Creek Watershed, South-Central

Texas. Archaeological Survey Report No.

130. Center for Archaeological Research, The University of Texas at San Antonio.

Kelley, J. Charles, and Thomas N. Campbell

1942 What are the Burnt Mounds of Texas? American Antiquity 7(3):319-322.

Kelley, J. Charles, Thomas N. Campbell, and Donald J. Lehmer

1940 The Association of the Archeological Materials with Geological Deposits in the Big Bend Region of Texas. Bulletin 8. Sul Ross State Teachers College, Alpine.
Kerr, Anne C., and Susan W. Dial

1998 Statistical Analysis of Unfluted Lanceolate and Early Bifurcate Stem Projectile Points. In Wilson-Leonard: An 11,000-Year Archeological Record of Hunter-Gatherers in Central Texas, Volume II, edited and assembled by Michael B. Collins, pp. 447-505. Studies in Archeology 31. Texas Archeological Research Laboratory, The University of Texas at Austin. Archeology Studies Program, Report 10. Environmental Affairs Division, Texas Department of Transportation.

Kibler, Karl W., and Ann M. Scott

2000 Archaic Hunters and Gatherers of the Balcones Canyonlands: Data Recovery Excavations at the Cibolo Crossing Site (41BX377), Camp Bullis Military Reservation, Bexar County, Texas. Reports of Investigations No. 126. Prewitt and Associates, Inc., Austin.

Kirkland, Forrest

1937 A Study of Indian Pictures in Texas. Bulletin of the Texas Archeological and Paleontological Society 9:89-119.

1938 A Description of Texas Pictographs. Bulletin of the Texas Archeological and Paleontological Society 10:11-40.

1939 Indian Pictures in the Dry Shelters of Val Verde County, Texas. Bulletin of the Texas Archeological and Paleontological Society 11:47-76.

Kirkland, F., and W. W. Newcomb Jr.

1967 The Rock Art of Texas Indians. University of Texas Press, Austin.

Kleinbach, Karl, Gemma Mehalchick, James T. Abbott, and J. Michael Quigg

1995 Other Analyses. In NRHP Significance Testing Of 57 Prehistoric Archeological Sites On Fort Hood, Texas, Volume II, edited by James T. Abbott and W. Nicholas Trierweiler, pp. 765-842. Archeological Resource Management Series, Research Report No. 34. United States Army, Fort Hood.

Lukowski, Paul D.

1988 Archaeological Investigations at 41BX1, Bexar County, Texas. Archaeological Survey Report No. 135. Center for Archaeological Research, The University of Texas at San Antonio. 
Lundelius, Ernest L. Jr.

1984 A Late Pleistocene Mammalian Fauna from Cueva Quebrada, Val Verde County, Texas. Special Publications of the Carnegie Museum of Natural History 8:456-481. Pittsburgh.

MacNeish, R. S.

1958 Preliminary Archeological Investigations in Sierra de Tamaulipas, Mexico. Transactions of the American Philosophical Society 48:6.

Mahoney, Richard B., Raymond P. Mauldin, and Steve A. Tomka

2002 Archeological Data Recovery Excavations along Becerra Creek (41WB556), Webb County, Texas. Archaeological Report No 321. Center for Archaeological Research, The University of Texas at San Antonio. Archeological Studies Program, Report 44. Texas Department of Transportation, Environmental Affairs Division, Austin.

Mallouf, Robert J., Daniel E. Fox, and Alton Briggs 1973 An Assessment of the Cultural Resources of Palmetto Bend Reservoir, Jackson County, Texas. Archeological Survey Report Number 11. Texas Historical Commission and Texas Water Development Board.

Martin, George C.

n.d. Preliminary Archaeological Survey of a Portion of the Texas coast Made by George C. Martin and Wendell H. Potter in 1927-1929. Privately printed by the author.

McGraw, A. Joachim

1983 Arroyo de los Muertos and Other Prehistoric Terrace Sites Along the Rio Grande, Laredo Texas. Archaeological Survey Report No. 106. Center for Archaeological Research, The University of Texas at San Antonio.

McGraw, A. Joachim, and Kay Hindes

1987 Chipped Stone and Adobe: A Cultural Resources Assessment of the Proposed Applewhite Reservoir, Bexar County, Texas. Archeological Survey Report No. 163. Center for Archeological Research, The University of Texas at San Antonio.

McKinney, Wilson W.

1981 Early Holocene Adaptations in Central and Southwestern Texas: The Problem of the Paleoindian-Archaic Transition. Bul- letin of the Texas Archeology Society 52:91120.

Jantz, Lee Meadows, Richard L. Jantz, Nicholas P. Herrmann, Corey S. Sparks, Katherine E. Weisensee, and Derinna V. Kopp

2002 Archaeological Investigations at the Last Spanish Colonial Mission Established on the Texas Frontier: Nuestra Señora del Refugio (41RF1), Refugio County, Texas, Volume II, Osteological Analysis. Archaeological Survey Report No. 315. Center for Archaeological Research, The University of Texas at San Antonio. Archeological Studies Program, Report 39. Texas Department of Transportation, Environmental Affairs Division, Austin.

Meltzer, David J., and Michael R. Bever

1995 Paleoindians of Texas: An Update on the Texas Clovis Fluted Point Survey. Bulletin of the Texas Archeological Society $66: 47-81$.

Newcomb, W. W. Jr.

1961 The Indians of Texas. University of Texas Press, Austin.

Nunley, J. Parker, Lathel F. Duffield, and Edward B. Jelks

1965 Excavations at Amistad Reservoir, 1962 Season. Miscellaneous Papers 3. T e x a s Archeological Salvage Project, The University of Texas at Austin.

Parsons, Mark L.

1962 Testing and Reconnaissance in Amistad Reservoir, Val Verde County, Texas. National Park Service and Texas Archeological Research Laboratory, The University of Texas at Austin.

19651963 Test Excavations at Fate Bell Shelter, Amistad Reservoir, Val Verde County, Texas. Miscellaneous Papers 4. Texas Archeological Salvage Project, The University of Texas at Austin.

Pearce, J. E., and A. T. Jackson

1933 A Prehistoric Rockshelter in Val Verde County, Texas. University of Texas Bulletin 3327, Austin.

Prewitt, Elton R.

1966 Preliminary Report on the Devil's Rockshelter. Texas Journal of Science 18(2):206-224.

1981 Cultural Chronology in Central Texas. 
Bulletin of the Texas Archeological Society 52:65-89.

1985 From Circleville to Toyah: Comments on Central Texas Chronology. Bulletin of the Texas Archeological Society 54:201238.

Prewitt, Elton R., Susan V. Lisk, and Margaret A. Howard

1987 National Register Assessments of the Swan Lake Site, 41AS16, on Copano Bay, Aransas County, Texas. Reports of Investigations No. 56. Prewitt and Associates, Inc., Austin.

Ricklis, Robert A.

1988 Archeological Investigations at the McKinzie Site (41NU221) Nueces County, Texas: Description and Contextual Interpretations. Bulletin of the Texas Archeological Society 58:1-76.

1989 Historical Cultural Ecology of the Karankawan Indians of the Central Texas Coast: A Case Study in the Roots of Adaptive Change. Ph.D. dissertation, Department of Geography, The University of Texas at Austin.

1995 Prehistoric Occupation of the Central and Lower Texas Coast: A Regional Overview. Bulletin of the Texas Archeological Society 66:265-300.

1996 The Karankawa Indians of Texas. An Ecological Study of Cultural Tradition and Change. University of Texas Press, Austin.

1999 The Spanish Colonial Missions of Espíritu Santo (41GD1) and Nuestra Señora del Rosario (41GD2), Goliad, Texas: Exploring Patterns of Ethnicity, Interaction, and Acculturation. Bulletin of the Texas Archeological Society 70:132-168.

Ruecking, F. H.

1953 The Economic System of the Coahuiltecan Indians of Southern Texas and Northeastern Mexico. Texas Journal of Science 5(4):480-497.

1955a The Social Organization of the Coahuiltecan Indians of Southern Texas and Northeastern Mexico. Texas Journal of Science 7(4):357-388.

1955b The Coahuiltecan Indians of Southern
Texas and Northeastern Mexico. Unpublished M. A. Thesis, The University of Texas, Austin.

Sánchez, Joseph P.

1992 From El Paso to Eagle Pass: Spanish Entradas along the Lower Rio Grande in the Sixteenth and Seventeenth Centuries. Bulletin of the Texas Archeological Society 63:53-66.

Sayles, E. B.

1935 An Archeological Survey of Texas. Medallion Papers XVII. Gila Pueblo, Globe, Arizona.

Schuetz, Meredith K.

1956 An Analysis of Val Verde County Cave Material. Bulletin of the Texas Archeological Society 27:129-160.

1961 An Analysis of Val Verde County Cave Material, Part II. Bulletin of the Texas Archeological Society 31:166-205.

1963 An Analysis of Val Verde County Cave Material, Part III. Bulletin of the Texas Archeological Society 33:131166.

Scott, R. F. IV, and D. E. Fox

1982 Excavations at Sites 41LK31/32 and 41LK202 in the Choke Canyon Reservoir, South Texas. Choke Canyon Series 8. Center for Archaeological Research, The University of Texas at San Antonio.

Sellards, E. H.

1940 Pleistocene Artifacts and Associated Fossils from Bee County, Texas. Bulletin of the Geological Society of America 51:16271658 .

Shafer, Harry J.

1963 Test Excavations at the Youngsport Site: A Stratified Terrace Site in Bell County, Texas. Bulletin of the Texas Archeological Society 34:57-81.

1977 Art and Territoriality in the Lower Pecos Archaic. Plains Anthropologist 19:228230.

1986 Ancient Texans. Texas Monthly Press, Austin.

Shafer, Harry J., and Vaughn M. Bryant Jr.

1977 Archeological and Botanical Studies at Hinds Cave, Val Verde County, Texas. 
Special Series 1. Anthropological Laboratory, Texas A\&M University, College Station.

Shiner, Joel L.

1983 Archeology of the Sheldon Site, Hidalgo County, Texas. Bulletin of the Texas Archeological Society 54:309-318.

Sorrow, William M.

1969 Archeological Investigations at the John Ischy Site: A Burned Rock Midden in Williamson County, Texas. Papers of the Texas Archeological Salvage Project No. 18. The University of Texas at Austin.

Steele, D. Gentry

1986 Analysis of Vertebrate Faunal Remains. In The Clemente and Herminia Hinojosa Site, 41JW8: A Toyah Horizon Campsite in Southern Texas, by Stephen L. Black, pp. 108-136. Special Report No. 18. Center for Archaeological Research, The University of Texas at San Antonio.

Steele, D. Gentry, and Cristi A. Hunter

1986 Analysis of Vertebrate Faunal Remains from 41MC222 and 41MC296, McMullen County, Texas. In The Prehistoric Sites at Choke Canyon Reservoir, South Texas: Results of Phase II Archaeological Investigations, by G. D. Hall, T. R. Hester, and S. L. Black, pp. 452-502. Choke Canyon Series 10. Center for Archaeological Research, The University of Texas at San Antonio.

Story, Dee Ann

1968 Archeological Investigations at Two Central Texas Gulf Coastal Sites. Report Number 13. State Building Commission Archeological Program, Austin.

1985 Adaptive Strategies of Archaic Cultures of the West Gulf Coastal Plain. In Prehistoric Food Production in North America, edited by R. I. Ford, pp. 19-56. Anthropological Papers 75. Museum of Anthropology, University of Michigan, Ann Arbor.

1990 Cutural History of the Native Americans. In The Archeology and Bioarcheology of the Gulf Coastal Plain, by Dee Ann Story, Janice A. Guy, Barbara A. Burnett, Martha Doty Freeman, Jerome C. Rose, D. Gentry Steele, Ben W. Olive, and
Karl J. Reinhard, pp. 163-366. Research Series No. 38. Arkansas Archeological Survey, Fayetteville.

Suhm, Dee Ann

1960 A Review of Central Texas Archeology. Bulletin of the Texas Archeological Society 29:63-107.

Suhm, Dee Ann, Alex D. Krieger, and Edward B. Jelks

1954 An Introductory Handbook of Texas Archeology. Bulletin of the Texas Archeological Society, Vol. 25.

Suhm, Raymond W.

1980 The La Paloma Mammoth Site, Kenedy County, Texas. In Papers on the Archaeology of the Texas Coast, edited by Lynn Highley and Thomas R. Hester, pp. 79-104. Special Report No. 11. Center for Archaeological Research, The University of Texas at San Antonio.

Takac, Paul R

1991 Underwater Excavations at Spring Lake: A Paleoindian Site in Hays County, Texas. Current Research in the Pleistocene 8:4648.

Taylor, Anna J., and Cheryl L. Highley

1995 Archeological Investigations at the Loma Sandia Site (41LK28): A Prehistoric Cemetery and Campsite in Live Oak County, Texas, Vol. 1 and 2. Studies in Archeology 20. Texas Archeological Research Laboratory, The University of Texas at Austin.

Taylor, Walter W.

1958 Archeological Survey of the Mexican Part of Diablo Reservoir, Val Verde County, Texas. In Appraisal of the Archeological Resources of Diablo Reservoir, Val Verde County, Texas, by J. Graham and W. B. Davis. Report to the National Park Service by the Inter-Agency Archeological Salvage Program, Field Office, Austin, Texas.

Taylor, Walter W., and Francisco G. Rul

1961 An Archeological Reconnaissance Behind Diablo Dam. Coahuila, Mexico. Bulletin of the Texas Archeological Society 31:153165 .

Tennis, Cynthia L.

2002 Archaeological Investigations at the Last Spanish Colonial Mission Established on the Texas Frontier: Nuestra Señora 
del Refugio (41RF1), Refugio County, Texas, Volume I, Archaeological Investigations. Archaeological Survey Report No. 315. Center for Archaeological Research, The University of Texas at San Antonio. Archeological Studies Program, Report 39. Texas Department of Transportation, Environmental Affairs Division, Austin.

Thoms, Alston V., and Steven W. Ahr

1996 Archaeological Studies at Birch Creek Unit and Yegua Creek Fishing-Access Area, Lake Somerville State Park, Burleson County, Texas, Interim Report, September 1996. Center for Environmental Archaeology, Texas A\&M University, College Station.

Thoms, Alston V., David D. Kuehn, Ben W. Olive, John E. Dockall, Patricia A. Clabaugh, and Rolfe D. Mandel

1996 Early and Middle Holocene Occupations at the Richard Beene Site: The 1995 Southern Texas Archaeological Association Field School Project. La Tierra 23(4):8-36.

Thoms, A. V., and R. D. Mandel

1991 The Richard Beene Site: A Deeply Stratified Paleoindian to Late Prehistoric Occupation in South-Central Texas. Current Research in the Pleistocene 9:4244.

Tomka, Steve A., Timothy K. Perttula, and Robert J. Hard

1997 Archaeology of the Rio Grande and Central Coastal Plains, Texas: A Planning Document (draft). Archaeological Survey Report No. 266. Center for Archaeological Research, The University of Texas at San Antonio.

Toomey, R. S. III, M. D. Blum, and S. Valastro Jr. 1993 Late Quaternary Climates and Environments of the Edwards Plateau, Texas. Global and Planetary Change 7:299320.

Turpin, Solveig

1982 Seminole Canyon: The Art and the Archeology. Research Report 83. Texas Archeological Survey, The University of Texas at Austin.

1984 The Red Linear Style Pictographs of the Lower Pecos River Region, Texas. Plains Anthropologist 29(105):181-198. 1986a Pictographs in the Red Monochrome Style in the Lower Pecos River Region. Bulletin of the Texas Archeological Society 55:123144.

1986b Toward a Definition of a Pictograph Style: The Lower Pecos Bold Line Geometrics. Plains Anthropologist 31(112):153-161.

1990 Rock Art and Its Contribution to Hunter Gatherer Archeology: A Case Study from the Lower Pecos River Region of Southwest Texas and Northern Mexico. Journal of Field Archaeology 17(3)263-281.

1991 Time out of Mind: The Radiocarbon Chronology of the Lower Pecos River Region. In Papers on the Lower Pecos Prehistory, edited by S. A. Turpin, pp. 1-49. Studies in Archeology 8. Texas Archeological Research Laboratory, The University of Texas at Austin.

1995 The Lower Pecos River Region of Texas and Northern Mexico. Bulletin of the Texas Archeological Society 66:541-560.

Tyler, R. C.

1996 The Big Bend, A History of the Last Texas Frontier. Texas A\&M University Press, College Station.

Walter, Tamra L.

1999 A Preliminary Report of the 1997 TAS Field School Excavations in Area A at Mission Espíritu Santo de Zuniga (41VT11), Victoria County, Texas. Bulletin of the Texas Archeological Society 70:97-121.

Wandsnider, L.

1997 The Roasted and the Boiled: Food Composition and Heat Treatment with Special Emphasis on Pit-Hearth Cooking. Journal of Anthropological Archaeology 16:1-48.

Weinstein, Richard A.

1992 Archaeology and Paleogeography of the Lower Guadalupe River/San Antonio Bay Region: Cultural Resources Investigations Along the Channel to Victoria, Calhoun and Victoria Counties, Texas. Coastal Environments, Inc., Baton Rouge.

Weir, Frank A.

1976 The Central Texas Archaic. Ph.D. dissertation, Department of Anthropology, 
Washington State University, Pullman.

Wesolowsky, Al B., Thomas R. Hester, and D. R. Brown

1976 Archeological Investigations at the Jetta Court Site (41TV151) Travis County, Texas. Bulletin of the Texas Archeological Society 47:25-87.

Willey, Gordon R., and Phillip Phillips 1958 Method and Theory in American Archae- ology. University of Chicago Press, Chicago.

Wilson, E. W.

1930 Burnt Rock Mounds of Southwest Texas. Bulletin of the Texas Archaeological and Paleontological Society 2:59-63.

Zintgraff, Jim W. and Solveig A. Turpin

1991 Pecos River Rock Art. McPherson Publishing Company, San Antonio. 
APPENDIX A: Glossary of Technical Terms 

Arrow point: Point used to tip an arrow, which is propelled by a bow.

Biface: Piece of conchoidally fracturing stone that has had flakes removed from both faces to create a tool.

Core: Piece of lithic material from which one or more flakes have been removed.

Dart point: Point used to tip a throwing spear or dart, which is propelled by an atlatl.

Debitage: Debris generated by the removal through percussion or pressure of flakes, chips, and chunks to make stone tools.

Fill section: Introduced fill used to elevate the approaches to a bridge above the surrounding terrain.

Flake: Generally thin piece of conchoidally fracturing stone with a positive bulb of percussion showing that it was removed from the parent piece by percussion or pressure.

Grog: Crushed fired clay added as temper to clay used in making ceramic vessels.

Hammerstone: Rock used as a hammer in making stone tools, crushing nuts, and so on.

Impact Evaluation: Onsite inspection documenting existing damage or other conditions that may preclude the presence of intact archeological deposits within the project area for a proposed Transportation Activity.

Megafauna: Very large animal.

Metate: Anvil of stone used, usually with a mano, to grind plant parts such as seeds.

Midden: Accumulation of occupational debris, particularly organic remains, burned rocks, or shells.

Projectile point: Inclusive term for arrow and dart points.

Sherd: A piece of broken pottery.

Survey: Fieldwork to locate archeological remains within the project area for a proposed Transportation Activity, including on-foot examination of the surface, shovel testing, and trenching by mechanical means where appropriate.

Survey with Geoarcheological Evaluation: Fieldwork to locate archeological remains within the project area for a proposed Transportation Activity, including examining and record trench walls or other exposures by a geomorphologist, quaternary geologist, physical geographer, soil scientist, or archeologist with the formal training and experience to apply the principles of geology to the evaluation of the pedological, stratigraphic, geomorphic, anthrogenic, and other conditions affecting the physical integrity of archeological deposits and the interpretation of archeological materials.

Temper: Nonplastic materials added to clay to decrease the risk of cracking when firing ceramic vessels.

Transportation Activity: any proposed project involving the development, design, construction, or maintenance of the state's intermodal transportation system. 

APPENDIX B: Letters and Letter Reports for Impact Evaluations and Surveys 

The interim reports for the Impact Evaluations and Surveys are on the CD-ROM, which is included only in selected copies. Authors of the reports were Christopher W. Ringstaff, Patrick McLoughlin, Corey Crawford, Ross C. Fields, Karl W. Kibler, E. Frances Gadus, Stephen M. Thompson, Timothy B. Griffith, and Cory J. Broehm. 
